$\frac{14}{10^{4}} /(8)^{10^{2}}$

(2)

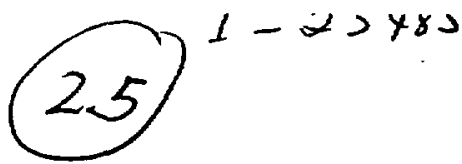

UCRL 92882

PREPRINT

Dir 1363.3

JCRL- -92882

DE86 001304

E. N. C. Dalder

M. C. Juhas

This paper was prepared for submittal to NUCLEAR BNGINEERING AND DESIGN

September 19, 1985

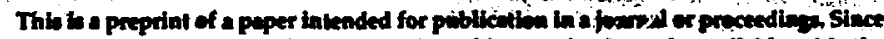

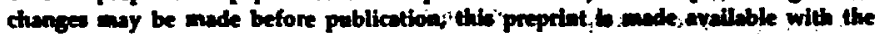
underctandias that $k$ will not be ctied er reproduced withent the pernibion of the anther.

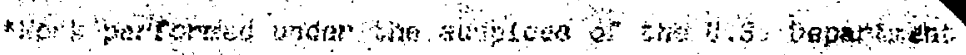

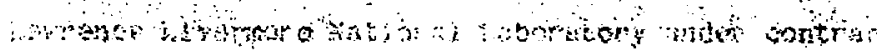




\title{
AUSTENITIC STAINLESS STEELS FOR CRYOGENIC SERVICE*
}

\author{
E. N. C. Dalder and M. C. Juhas ${ }^{\dagger}$ \\ University of California \\ Lawrence Livermore National Laboratory \\ Livermore, California 94550
}

\section{ABSTRACT}

Presently available information on austenitic $\mathrm{Fe}-\mathrm{Cr}-\mathrm{Ni}$ stainless steel plate, welds, and castings for service below $77 \mathrm{~K}$ are reviewed with the intent (1) of developing systematic relationships between mechanical properties, composition, microstructure, and processing, and (2) of assessing the adequacy of these data bases in the design, fabrication, and operation of engineering systems at $4 \mathrm{~K}$.

\section{DISCLAIMER}

\begin{abstract}
This report was prepared as an account of work sponsored by an agency of the United States Government. Neither the United States Government acr any agency thereof, nor any of their employces, makes any warranty, express or implied, or assumes any legal liability or responsibility for the accuracy. completeness, or usefulness of any information, apparatus, product, or process disclosed, or represents that its use would not infringe privately owned rights. Reference herein to any specific commercial product, process, or service by trade name, trademark, manufacturer, of otherwise does not necessarily constitute or imply its endorsement, recommendation, or favoring hy the United States Government or any agency thereor. The views and opinions of authors expressed berein do not necessarily state or reflect those of the United States Government or any agency thereof.
\end{abstract}

*Work performed under the auspices of the U.S. Department of Energy by the Lawrence Livermore National Laboratory under contract number W-7405-ENG-48.

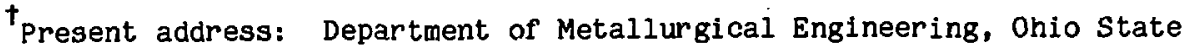
University, Columbus, onio 43210. 


\section{Introduction}

Many of the most challenging needs for cryogenic materials relate to the design and construction of high-field superconducting magnets that operate at temperatures of $4 \mathrm{~K}$ or below. Three distinct types of materiais are used in these magnets: superconducting wire to carry the current that creates the field, high-strength steels to position and support the conductor, and electrical insulators to separate the wires from one another. There are important problems with each of these material types, but the present paper is biased toward metals and is focused on materials needs and current research in structural alloys.

The materials needs for high-field superconducting magnets are set by the performance targets of the high-field magnets that will be used in future systems. High-field superconducting magnets are central to a number of new technologies. Those that have excited major research and development efforts within the linited States include magnetic fusion devices for energy production, magnetic accelerators for research in high-energy physics, and whole-body nuclear magnetfc resonance (NMR) for medical diagnosis. The relevant materials research is primarily intended to support magnetic fusion and high-energy physics. While medical NMR will likely create a major market for superconducting wire, both current and projected systems require relatively low-field magnets that can be built with existing materials [1].

\section{Superconducting magnet systems and materials needs}

The current systems and materials needs for magnetic fusion are discussed under the following two headings. 


\subsection{Fusion energy experiments}

The United States Department of Energy (DOE) currently supports research on two basic concepts for magnetic fusion energy, namely, toroidal confinement and mirror confinement [2]. The two concepts differ in the way the cylindrical plasma is bounded along its length. Both use a high magnetic field to heat the plasma by compressing it into a cylinder. Thus superconducting magnets must be employed to create that field if magnetic fusion energy is to be technically feasible and commerically viable.

In the toroidal concept, the plasma is closed on itself to form a torus. The best known machine design is the tokamak, which is the basis for the Tokamak Fusion Test Reactor (TFTR) [3] the major test facility within the United States (Fig. 1). The TFTR employs a peak magnetic field that is approximately $10 \mathrm{~T}$ at the magnet conductor (approximately $5 \mathrm{~T}$ at the plasma center). However, the magnets are copper electromagnets. It was decided to develop the superconducting magnet systems for toroidal machines separately from the experiment itself. This decision led to the Large Coil Project at the Oak Ridge National Laboratory [4], in which six large 8-T superconducting magnets are being assembled for magnet system tests. The six magnets were chosen to represent different design and materials concepts. Three of the six large coils were constructed in the United States, two in Europe, and one in Japan. Five utilize NbTi superconducting wire; the sixth, built by Westinghouse in the United States, utilizes $\mathrm{Nb}_{3} \mathrm{Sn}$.

A next-generation tokamak machine is now in design [5]. The device is called the TIBER (Tokamak Ignition and Burn Experimental Reactor). The physics objective of TIBER is to achieve plasma ignition and demonstrate the technical feasibility of magnetic fusion as a power source. While the 
magnetic field of TIBER is not finalized, the toroidal field coils that confine the plasma will have a peak field near $12 \mathrm{~T}$ at the conductor. The superconducting poloidal field coils that shape the field will operate in the 7- to $15-T$ range.

A companion toroidal fusion experiment is the Alcator DCT at the Massachusetts Institute of Technology [6]. This device will employ 10-T toroidal magnets that generate a 7-T field at the plasma center and also employ 7-T poloidal magnets. Both magnet sets will be superconducting. The initial design envisages Nb3Sn toroidal coils and NbTi poloidal colls.

In the mirror fusion concept, the plasma is a linear cylinder that is sealed at its ends by an arrangement, of high-field magnets. The major facility in the United States is the Mirror Fusion Test Facility (MFTF-B) [7], located at the Lawrence Livermore National Laboratory (LLNL). Figure 2 is an artist's drawing of the MFMF-B, which is now under construstion at LLNL. The plasma is contained in a central tube of solenoid magnets. The zolenoid is completed at either end by a combination of magnets, including two, small, high-field, axicell choke coils; two transition magnets to shape the plasma; and a large, yin-yang, mirror coil set. Current plans call for a peak field of 2 to $3 \mathrm{~T}$ in the solenoid, 12 to $13 \mathrm{~T}$ in the small axicells, 5 to $6 \mathrm{~T}$ in the transition coils, and 7 to $8 \mathrm{~T}$ in the yin-yang coil set. All magnets will be superconducting. Two of the high-field axicells will be hybrid magnets with NoTi outer solenoids and $\mathrm{Nb}_{3} \mathrm{Sn}$ inserts. The current design employs NoTi conductors in all other magnets.

The first of the large yin-yang coll sets for the MFTF-B was constructed as part of an earlier project. One pair of yin-yang magnets is shown in Fig. 3 to illustrate its size. The second yin-yang coil set has now been wound. 
As of this writing (July 1985), the winding of the axicells and transition cells is complete and coils have been assembled into the reactor vessel.

\subsection{Practical design constraints}

Aimost half of the cost and the technical difficulty of large magnets is associated with their force-restraining structure. Magnetic field contours can be thought of as pressure surfaces with 12-T fields corresponding to a pressure of $570 \mathrm{~atm}$, as compared to the usual 200-atm design pressure for steam boilers. While pure tension geometries are possible, both for tokamaks [8] and for mirrors [9], practical manufacturing and fault considerations cause bending stresses to be present as well.

No code or standards guidance exists for the design of magnet structures. Instead, it has become common practice to use portions of various codes, such as Section III or Section VIII of the ASME Boiler and Pressure Vessel Code, and depend on one's intuitions and calculations. However, it is easy to show trat blind obedience to existing codes can result in either excessively heavy or dangerously fracture-prone structures. For example, paragraph UA-500 of Section VIII of the ASME code recommends that the lower of $1 / 4$ of the tensile strength or $5 / 8$ of the yield strength be used for design. For some stainless steels, such as Type $304[\mathrm{Fe}-19 \mathrm{Cr}-9 \mathrm{Ni}-2 \mathrm{Mn}-0.08 \mathrm{C}]$, the resulting design stress would be limited by yield strength and be excessively conservative, considering the very high tensile strength and toughness of the alloy at low temperatures. For other stainless steels, such as Nitronic 40 $\left[\mathrm{Fe}-21 \mathrm{Cr}-6 \mathrm{Ni}-9 \mathrm{Mn}-.02 \mathrm{C}-.3 \mathrm{~N}_{2}\right]$, the Charpy impact tests at $77 \mathrm{~K}$ are not representative of the toughness and crack growth properties at $4 \mathrm{~K}$. 
Thus insufficient fracture resistance might result at $4 \mathrm{~K}$ if the materialselection is based on $77 \mathrm{~K}$ data.

It is premature to adopt a code, since little operational experience exists for superconducting magnets. Table 1 summarizes present practice for the design of the MFTF superconducting-magnet structures. The criterion that results in the lowest stress is used. Note that the fractions of yield and uitimate tensile strength used as design allowables are higher that those recommended in Paragraph UA-500, Section VIII, of the ASME Boiler and Pressure Vessel Code. This is because the forces on magnet structures are resolvable by the use of sophisticated computer codes. Also, the helium environment is noncorrosive. More restrictive, however, is the design stress dependence upon the material's fracture-toughness at $4 \mathrm{~K}$ because of tendency of materials to emiorittle at low temperature, especially in the presence of a neutron fluence. Here, the plane-strain fracture toughness, $\mathrm{K}_{I C}$, must be known and be compatible with the permissible flaw size, 2a. More difficult to obtain is the fatigue crack-growth rate per cycle of loading, da/dn, but analyses based on the use of such data represents a powerful design tool to handle cyclic loading conditions. Linear-ejastic fracture-mechanics codes like FLAGRO-II can be used to predict cyclic life with crack-growth data from compact-tension fracture-toughness test specimens [10].

For a material to withstand high magnetic forces in combined cryogenic and nuclear environment, unusual structural-material selection criteria must be satisfied. Because of limited space for structure, the material must have both high yleid and tensile strength at $4 \mathrm{~K}$. The material must also have a high eiastic modulus and a thermal expansion coefficient compatible with that of the superconductor to keep from overstraining the latter on cooling. The structural material must be tough and have a low fatigue-crack rate, so that 
critical flow sizes will not be exceeded, thus avoiding brittle fracture. The structural material should also be relatively inexpensive, easily machined, and weldable without post-weld heat treatments. Table 2 summarizes such desirable material properties.

This survey covers available information on $4 \mathrm{~K}$ mechanical and metallurgical behavior of austenitic stainless steels and their weldments as they are currently (July 1985) used in the construction of superconducting magnet systems in the U.S.A., Japan, and Western Europe. Some of the abbreviations and acronyms used in this paper are given in Table 3.

\section{Austentic stainless steels}

Austenitic $\mathrm{Cr}-\mathrm{Ni}$ and $\mathrm{Cr}-\mathrm{Ni}-\mathrm{N}_{2}$ wrought stainless steels, of the type whose compositions are given in Table 4 for wrought materials and in Table 5 for cast materials, are the most widel $j$ used structural materials in superconducting magnets. The principal drawbacks are the high construction costs and the need for careful control of composition to insure microstructure stability under operational conditions.

\subsection{Microstructural stability}

Candidate alloys for construction of superconducting magnets must be resistant to microstructural transformations during fabrication and service, since such $\because$ isformations involve formation of brittle phases, volume changes and/or dimensional distortions, creation of localized high-residual stresses, and the development of significant ferromagnetic behavior in previously 
paramagnetic materials. While austenitic stainless steels are considered to be fully austenitic and paramagnetic, many of these wrought materials are neither fully austenitic nor fully paramagnetic, especially after welding and/or cold-forming, followed by exposure to cryogenic temperatures. Cast alloys have their compositions optimized to produce 5 to $25 \%$ of a ferromagnetic phase upon solidification, which prevents formation of defects during solidification.

Other than austenite, three metallurgical phases that can occur in austenitic stainless steels and create any or all of the problems mentioned above are delta $(\delta)$ ferrite, ensilon ( $\varepsilon$ ) martensite, and alpha-prime ( $\left.\alpha^{\prime}\right)$ martensite. Both the $\delta$-ferrite and $a^{\prime}$-martensite are ferromagnetic. Empirical methods exist for predicting the presence and amounts of $\alpha^{\prime-}$ martensite and $\delta-f$ errite phases. Usea of these methods to develop compositional recommendations for Type 304LN austenitic stainless steel used in the magnet cases of the MFTF-B are discussed below.

\subsubsection{Delta-ferrite in austenitic stainless steels}

Delta-ferrite is a body-centered, cubic ( $B C C)$, metastable solid solution that can occur in otherwise face-centered, cubic (FCC), austenitic stainless steels. Delta-ferrite usually forms on cooling as small, irregularly shaped, dendrites in both welds and solidifying ingots. Extensive information [11-23] is available on the occurrence and effects of delta ferrite in austenitic stainless steel weldments. Delta ferrite aids in improving the not cracking or "micro-fissuring" resistance of welds in austenitic stainless steels. However, as DeLong [8] and Read [23] have stated, increasing ferrite content of austenitic stainless steel weldments causes progressive decreases in the 
77-K impact toughness and 4-K fracture toughness (Fig. 4). Since deltaferrite is ferromagnetic, the permeability of a stainless steel weldment, casting, or wrought product whose composition has not been optimized to insure the absence of delta-ferrite will increase with increasing ferrite content.

To develop compositional recommendations for Type 304LN stainless steel that would insure freedom from delta-ferrite in the wrought form, we can use Long and DeLong's [17] revised Shaeffler constitution diagram for stainless steel weld metal (Fig. 5) and the companion equations for "nickel equivalent", $\mathrm{E}_{\mathrm{Ni}}$, and "chromium equivalent", $\mathrm{E}_{\mathrm{Cr}}$ :

$$
\begin{aligned}
& E_{\mathrm{Ni}}=\% \mathrm{Ni}+30 \% \mathrm{C}+30 \% \mathrm{~N}_{2}+0.5 \% \mathrm{Mn} \\
& E_{\mathrm{Cr}}=\% \mathrm{Cr}+\% \mathrm{Mo}+1.5 \% \mathrm{Si}+0.5 \% \mathrm{Cb}
\end{aligned}
$$

The nickel equivalent represents the effective roles of alloy additions that stabilize austenite, while the chromium equivalent represents the effective roles of alloy additions that stabilize delta-ferrite (or alphaprime martensite).

By substituting into Equations (1) and (2), the values of alloy additions given in Table 6 for Type 304LN stainless steel, we obtain the resulting values of $E_{N i}$ and $E_{C r}$ that are given in the lower part of Table 6 . It is assumed that minimum levels of $C, M n$, and $S i$ will be set as shown in Table 5. The reasons for assuming these values are as follows:

a. C Levels - Less than $0.01 \% \mathrm{C}$ results in the weaker "ELC" special order material and requires extremely careful selection of low-carbon starting material for the charge as well as expensive 
melting and deoxidizing procedures [24]. Hence, a minimum carbon content of $0.01 \%$ was assumed.

b. $\quad \mathrm{Mn}$ and $\mathrm{Si}$ ievels - Minimum $\mathrm{Mn}$ and $\mathrm{Si}$ contents vare taken as $25 \%$ of the maximum specified levels of $2.0 \%$ and $1.0 \%$, respectively, based on unpublished data [25] and the need for at least $0.25 \% \mathrm{Si}$ for effective deoxidation [24].

Results of the calculations summarized in Table 5 are plotted on a modifled DeLong diagram (Fig. 5). Heats of 304LN that are low in austenitic stabilizers ( $\mathrm{Ni}, \mathrm{C}, \mathrm{N}$, and $\mathrm{Mn}$ ) and high in ferrite stabilizers ( $\mathrm{Cr}$ and $\mathrm{Si}$ ) may contain up to 12 to $14 \%$ ferrite. Heats that are low in $\mathrm{Ni}$ and $\mathrm{N}_{2}$ might contain some alpha-prime martensite.

The composition of Type $304 \mathrm{LN}$ should fall above the "zero-percent magnetic ferrite" line (line AD in Fig. 5) to avoid occurrene of ferromagnetic phases. Since this is a straight line,

$$
\frac{E_{N i}-E_{N i_{A}}}{E_{N i_{D}}-E_{N i_{A}}}=\frac{E_{C r}-E_{C r_{A}}}{E_{C r_{D}}-E_{C r_{A}}},
$$

where

$$
\begin{aligned}
& E_{N i_{A}}=13.4 \%, E_{N i_{D}}=17.7 \%, \\
& E_{C r_{A}}=18.4 \%, \quad E_{C r_{D}}=21.5 \%,
\end{aligned}
$$


(values obtained from Table 6 and Fig. 5). Solving for $E_{\mathrm{Ni}}$ in terms of $\mathrm{E}_{\mathrm{Cr}}$ gives

$$
\mathrm{E}_{\mathrm{Ni}}=1.613 \mathrm{E}_{\mathrm{Cr}}-16.277
$$

Substituting in the chemical compositional variants of $E_{\mathrm{N} 1}$ and $E_{\mathrm{Cr}}$ from Equations (1) and (2), respectively, we obtain

$\% \mathrm{Ni}+30 \% \mathrm{C}+30 \% \mathrm{~N}_{2}+0.5 \% \mathrm{Mn}=1.613 \% \mathrm{Cr}$

$$
+1.613 \% \mathrm{MO}+2.420 \% \mathrm{Si}+0.807 \% \mathrm{Cb}-16.277
$$

Equation (3B) indicates composition levels of the major alloy additions in austenitic stainless steels (such as Type 304LN) that will insure avoidance of formation of delta-ferrite on solidification. Similar procedures may be used for other austenitic stainless steels.

For the MFTF-B magnet case, an average $4-\mathrm{K}$ yield strength of $828 \mathrm{MPa}$ was desired, and a minimum $4-\mathrm{K}$ yield strength of $690 \mathrm{MPa}$ was required. From Fig. 6, where the yield strengths of various $\mathrm{N}_{2}$-strengthened austenitic stainless steels are plotted against $\sqrt{C+N}$, one obtains 


$$
\sqrt{C+N}=0.3800 \text { or } C+N=0.14449 \text {. }
$$

At a mid-range $C$ content of $0.015 \%, N=0.13 \%$.

Using the minimum values of $\mathrm{C}, \mathrm{Mn}, \mathrm{Si}$, and $\mathrm{Cr}$ given in Table 5. with $\mathrm{Cb}$ and Mo levels set equal to zero, the amount of iv 1 necessary to just avoid formation of delta-ferrite is calculated as follows:

$$
\begin{aligned}
& x \mathrm{Ni}+30(0.01)+30(0.13)+0.5(0.5)-1.613(18.0) \\
& +2.420(0.25)-16.277 \\
& \mathrm{Ni}+4.45=13.362
\end{aligned}
$$

$$
\% \mathrm{Ni}=8.912 \%
$$

Hence, a possible composition range in weight percent for Type 304LN for this application mignt be:

$\begin{array}{lccccc}\underline{\mathrm{C}} & \underline{\mathrm{Mn}} & \underline{\mathrm{Si}} & \underline{\mathrm{Cr}} & \underline{\mathrm{Ni}} & \underline{N_{2}} \\ \underline{0.03} & \underline{2.00} & \underline{1.00} & \underline{20.00} & \underline{12.00} & \underline{0.15} \\ 0.01 & 0.50 & 0.25 & 18.00 & 9.00 & 0.13\end{array}$




\subsubsection{Martensite in austenitic stainless steels}

Martensite is a metastable decomposition product of the FCC austenitic solid solution that is formed by a diffusior:less transformation in rapidly cooled iron-based alloys. Formation of martensite in austenitic stainless steels at and above room temperature is usually suppressed by the presence of significant amounts of austent te stabilizers such as $\mathrm{Mn} ;{ }^{\prime} \mathrm{Ni}$, and $\mathrm{N}_{2} \cdot$ However, martensite will form in many plastically strained austenitic stainless steels at or below a temperature, $M_{D}$, that depends on the steel's composition, or in situations where the undeformed austenite is cooled to a low enough temperature, $M_{S}[21,26-37]$. An excellent review of the physical metallurgy of martensite-formation in Fe-Cr-Ni stainless steels is given by Rerd [38]. Formation of martensite in an otherwise austenitic alloy creates residual stresses associated with a volume expansion and creates ferromagnetic behavior, both considered undesirable in superconducting magnets. Often, verification test results of candidate cryogenic structural materials are not available during the conceptual design period. However, empirical predictive equations are available for evaluation of the microstructural stability of austenitic stainless steels that are subjected both to very low temperatures and to plastic strain.

Expression for the temperature(s) at which martensite might form because of cooling to very low temperatures, without the assistance of plastic deformation, i.e., $M_{S}$, were developed by both Larbalestier and King [31], and Hull [11],

$$
\begin{aligned}
M_{S}( \pm 50 K) & -1578-61.1 \% \mathrm{Ni}-41.7 \% \mathrm{Cr}-33.3 \% \mathrm{Mn} \\
& -27.8 \mathrm{Si}-1667 \%(\mathrm{C}+\mathrm{N})-36.1 \% \mathrm{Mo}
\end{aligned}
$$


Equation (4) was developed for steels in the composition ranges typified by Types $304(\mathrm{~L})(\mathrm{N})$ and $316(\mathrm{~L})(\mathrm{N})$.

$$
\begin{aligned}
M_{S}(+80 \mathrm{~K}) & -2700106 \% \mathrm{Ni}-84.8 \% \mathrm{Cr}-97.5 \% \mathrm{Mn} \\
& -99.6 \% \mathrm{Mo}-66.8 \% \mathrm{Si}-230 \% \mathrm{~V}-325 \% \mathrm{Ti} \\
& -532 \% \mathrm{Al}-4304 \% \mathrm{C}-6084 \% \mathrm{~N}_{2}-91.2 \% \mathrm{cb} \\
& -136 \% \mathrm{Ta}-152.6 \% \mathrm{CuO} 24.4 \% \mathrm{Co}
\end{aligned}
$$

Equation (5) was developed for steels with higher $M n$ and $N_{2}$ contents than Type $304 \mathrm{~s}$ but is, to first order, applicable.

Substituting the values of alloy-composition that will avoid formation of delta-ferrite and letting the values of any alloy addition not specified therein be zero, we obtain the results shown in Table 6 for calculated $M_{S}$ values. These results indicate that the Type 304LN composition range developed to avoid formation of delta-ferrite for the MFTF-B magnet cases appears to be marginally stable against transformation to $\alpha^{\prime}$-martensite on cooling to $4 \mathrm{~K}$ in the unstrained condition. The term "marginally stable" is used because, in addition to the statement on standard error of Equations (4) and (5) mentioned above, the $\mathrm{M}_{S}$ of the low composition alloy calculated with Equation (4) is about $21 \mathrm{~K}$, i.e., slightly above absolute zero. Additional austenite stability could be conferred by raising the lower limit on $\mathrm{N} i$ from 9.0\% to 10.0\%. Minimum nitrogen levels should not be raised, however, as this may raise the minimum $4-\mathrm{K}$ yield strength to values above those attainable with weld metals with good $4-K$ fracture toughness.

The composition range of Type $304 \mathrm{LN}$ is metastable with respect to formation of $\alpha^{\prime}$-martensite because of extensive plastic strain, since calculated $M_{D}$ values 1 fe at or above room temperature. However, strain- 
induced nartensite formation is not expected to be a problem so long as the maximum strains developed during assembly or service are on the order of the yield strength strain, i.e., $0.2 \%$.

\subsubsection{Comparison of predictions of austenite stability with experiment}

While there are many experimental observations as to the occurrence extent of transformation of austenite to $\alpha^{\prime}$-martensite in many grades of austenitic stainless steels [26-37], very little work had been done on Type 304LN prior to construction of MFTF-B. Larbalestier and King [32] found that Type 304LN with $11.55 \% \mathrm{Ni}$ and $0.20 \% \mathrm{~N}_{2}$ and Type $304 \mathrm{~N}$ with $10.47 \% \mathrm{Ni}$ and $0.18 \%$ $N_{2}$ did not transform to martensite after cycling 11 times between room temperature and either $77 \mathrm{~K}$ or $4 \mathrm{~K}$. Samples were evaluated after annea:ing to simulate material received from the mill, after machining, and after an extreme sensitizing treatment ( $973 \mathrm{~K} / 168$ hours) that simulated any effects due to thermal cycling during welding. These results are good confirmation of the calculated results presented in Table 6 for $M_{S}$ behavior, as well as the microstructural stability of these steels. Regarding the behavior of Types $304 \mathrm{LN}$ and $304 \mathrm{~N}$ steels after inducing plastic deformation at $4 \mathrm{~K}$ by tensile testing to failure, extensive results reported by Larbalestier and King [32], Randak et al.[37], and Dalder [39] are summarized in Table 7. At the grip section of the tensile specimens, where strains of the order of $1 \%$ are experienced, no evidence of strain-induced $\alpha^{\prime}$-martensite was seen.

In summation, it appears that, at least, qualitative experimental confirmation both of the predictive capabilities of Equations (4-6) and of stability of Type 304LN under credible operating conditions for the MFTF-B magnet-cases can be assessed by the methods described. 


\subsection{Mechanical properties}

\subsubsection{Wrought alloys}

For comparison of material strength versus fracture resistance, a plot of 4-K plane-strain fracture toughness, $K_{I C}$, versus yield strength, $\sigma_{y}$, is used (see Fig. 7). All $K_{\text {IC }}$ values are conversions from the values determined by the elastic-plastic $\mathrm{J}$-integral test [40-41]. Note that the relatively weak $\left(\sigma_{y}<690 \mathrm{MPa}\right)$ but tough $\left(K_{I C}>275 \mathrm{MPa} \cdot \mathrm{m}^{1 / 2}\right)$, compositions are those with less than about $0.05 \% \mathrm{~N}_{2}$ and carbon levels below $0.03 \%$, such as Types $304 \mathrm{~L}$ $(19 \mathrm{Cr}-9 \mathrm{Ni}-0.03 \mathrm{C} \max$.$) and 316 \mathrm{~L}(17 \mathrm{Cr}-12 \mathrm{Ni}-2 \mathrm{Mo}-0.03 \max$. [42-46]. For intermediate yield strengths in the range 690 to $1035 \mathrm{MPa}$ and with fracture toughness values in the range of 200 to $275 \mathrm{MPa} \cdot \mathrm{m}^{1 / 2}, 0: 10$ to $0.16 \%$ additions of $\mathrm{N}_{2}$ to the Types $304 \mathrm{~L}$ and $316 \mathrm{~L}$ bases are an effective and economical means of yield-strength enhancement [42-53], as well as a means of stabilization of the austenitic microstructure against both thermally-induced and strain-induced martensite formation $[36,47,49]$. Steels with these compositions are being used in the construction of superconducting magnet structures for the magnetic fusion energy and magnetohydrodynamic (MHD) programs. Type 304LN was the structural material for the General DynamicsConvair large coil, the General Electric CDIF MHD magnet, and the MFTF-B magnet cases. Type $316 \mathrm{LN}$ was used for the General Electric Company's large coil structure.

Present practice is to use the restricted carbon content ( $C \leq 0.03 \%)$ "L" grades to minimize grain-boundary carbide precipitation during welding thermal cycles, called "sensitization", and tho resulting loss in toughness. Two examples of this are seen on Fig. 7: 
- Sensitization of Type $310 \mathrm{~s}(25 \mathrm{Cr}-20 \mathrm{Ni}-2 \mathrm{Mn}-0.05 \mathrm{C}$ ) caused by furnace cooling after annealing reduced the $4-K K_{I C} 38 \%$, from $248 \mathrm{MPa} \cdot \mathrm{m}^{1 / 2}$ to $180 \mathrm{MPa} \cdot \mathrm{m}^{1 / 2}$ with no change in $4-\mathrm{K} \sigma_{\mathrm{y}}[54]$.

- Sensitization of Type 304LN $(19 \mathrm{Cr}-10 \mathrm{Ni}-2 \mathrm{Mn}-.02 \mathrm{C}-.15 \mathrm{~N})$ by heat-treating at $922 \mathrm{~K}$ for 16 hours and furnace cooling reduced the $4-\mathrm{K} \mathrm{K}_{\mathrm{IC}} 51 \%$, from $275 \mathrm{MPa} \cdot \mathrm{m}^{1 / 2}$ to $182 \mathrm{MPa} \cdot \mathrm{m}^{1 / 2}$, with no change in $4-K \quad \sigma_{y}[39]$.

For yield strengths above $1035 \mathrm{MPa}$, such strengths are, in principle, attainable by a combined carbon and nitrogen content of about $0.2 \%$ or by a $\mathrm{N}_{2}$ content of about $0.17 \%$ for maintenance of the "L" grain maximum carbon content of $0.03 \%$ (Fig. 6). However, it is difficult to purchase Types $304 \mathrm{~L}$ or $316 \mathrm{~L}$ bases with these nitrogen levels in commercial quant.iies from U.S. steel suppliers. Problems quoted by steel producers include difficulties in production of pore-free ingots at high $\mathrm{N}_{2}$ contents, embrittlement of ingots by grain-boundary precipitation of $\mathrm{Cr}_{2} \mathrm{~N}$ during solidification and subsequent hot working, and difficulties with incorporation of high-N $\mathrm{N}_{2}$ scrap in steel-plant recycling procedures $[55,56]$. Hence, for yield strengths beyond $1035 \mathrm{MPa}$, present practice is to use $\mathrm{Mn}^{-\mathrm{N}_{2}}$-modified austenitic stainless steels. Increased levels of $\mathrm{Mn}$ are used to increase nitrogen solubility and raise the 4-K yield strength to levels in excess of $1380 \mathrm{MPa}$. Unfortunately, some of these materials suffer a serious decrease in fracture toughness at $4 \mathrm{~K}$, to levels below $100 \mathrm{MPa} \cdot \mathrm{m}^{1 / 2}$, as discussed by Read and Reed [57] for the $22 \mathrm{Cr}$ $12 \mathrm{Ni}-5 \mathrm{Mn}-0.3 \mathrm{~N}-.03 \mathrm{C}$ alloy. This loss of toughness is associated with incomplete solution of a grain-boundary phase, such as $M_{23}(C, N)_{6}$ carbonitride. Improper melting practices and thermomechanical processing [58] causes similar 
loss of cryogenic fracture toughness in the $21 \mathrm{cr}-9 \mathrm{Mn}-6 \mathrm{Ni}-0.03 \mathrm{C}-0.3$ $\mathrm{N}$ alloy. In addition to these problems, the unavailability of welding consumables with $4-K$ yield-strengths that match those of the corresponding base metals at adequate fracture-toughness levels has limited the use of these materials in the as-welded condition for MFE magnet structures.

The available 4-K load-controlled [59] and strain-controlled [42,60-61] fatigue data for wrought stainless steels are presented in Figs. 8 and 9 , respectively. Using the data presented in Fig. 8 to evaluate the fatiguenotch sensitivity, $q$, at the NiTF-B design-point [62] of 4000 cycles, where $q$ is defined as [63],

$$
q=\frac{K_{F}-1}{K_{T}-1}
$$

and

$$
K_{F}=\frac{\sigma_{\text {smooth }}}{\sigma_{\text {notched }}}
$$

at a given number of cycles, in this case 4000. A material that experiences no reduction in fatigue because of a notch $\left(K_{F}=1\right)$ has a $q$ of zero, while a material in which the notch has its full theoretlcal effect $\left(K_{F}=K_{T}\right)$ has a $q$ of 1.0 . 


$\begin{array}{ccc}\text { Material } & \mathrm{K}_{\mathrm{F}} \text { at } 4000 \text { Cycles } & \mathrm{g} \\ \text { N1tronic 40 } & 1.51 & 0.243 \\ 310 \mathrm{~S} & 1.35 & 0.167\end{array}$

Examination of the strain-controlled fatigue data in Fig. 9 yields no clearcut correlation between the fatigue performance of a steel and its yield strength, as Nitronic 40 has a $4-\mathrm{K}$ yield-strength of $1380 \mathrm{MPa}$ but is weaker in fatigue beyond 2000 cycles than Type 304L with a 4-K yield strength of about $350 \mathrm{MPa}$. Perhaps the excellent cyclic performance of Type 310 is associated with its excellent microstructurai stability, as 1 t is the only one of the six steels tested that does not normally undergo some strain-induced martensite formation at $4 \mathrm{~K}$.

The avallable 4-K fatizue crack-growth performance of various wrought austenitic siainless steels $[44,48,51,53,57,64-72]$ is presented in 1 igs. 10 to 13 and summarized in Fig. 14. Three types of behavior are seen, based on the degree of stability of the austenitic matrix with respect to stress-induced decomposition to $\alpha^{\prime}$-or $\varepsilon$-martensite and on th' exter.t to which grain-boundary carbonitric'e precipitation occurs, as previously observed by Tobler et al. $[64,72]:$

- Some alloys are unstable and transform to a'- or $\varepsilon$-martensite during fatigue-crack growth at $4 \mathrm{~K}$. Alloys such as Type $304(19 \mathrm{Cr}-10 \mathrm{Ni}$ - $2 \mathrm{Mn})$ and Type $316(17 \mathrm{Cr}-12 \mathrm{NI}-2 \mathrm{Mn}-2.5 \mathrm{Mo})$, and their controlled carbon and nitrogen variants, Types $304\left(L_{1}\right)(N)$ and $316(\mathrm{~L})(\mathrm{N})$, Nitronic $33(18 \mathrm{Cr}-13 \mathrm{Mn}-3 \mathrm{Ni}-0.35 \mathrm{~N})$, Nitronic 40 $(21 \mathrm{Cr}-9 \mathrm{Mn}-6 \mathrm{Ni}-0.35 \mathrm{~N})$, and Nitronic $50(22 \mathrm{Cr}-12 \mathrm{Ni}$ 
- $5 \mathrm{Mn}-2 \mathrm{Mo}-0.3 \mathrm{~N})$, and the Soviet $13 \mathrm{Cr}-19 \mathrm{Mn}-0.2 \mathrm{~N}$ alloy

fall in this class. Within this class, there is considerable variation in fatigue-crack growth rate from alloy to alloy, about a factor of 7 at a $\Delta K$ range of $30 \mathrm{MPa} \cdot \mathrm{m}^{1 / 2}$ (Fig. 11), or even within the same grade of alloy, such as Type 304 (Fig. 12), a factor of 10 at a constant $\Delta K$ range of $30 \mathrm{MPa} \cdot \mathrm{m}^{1 / 2}$.

- Some alloys are stable and did not show evidence of having transformed to $\alpha^{\prime}-$ and/or $\varepsilon$-martensite during testing at $4 \mathrm{~K}$. Alloys such as Type $310 \mathrm{~S}(25 \mathrm{Cr}-20 \mathrm{Ni}-2 \mathrm{Mn}-0.08 \mathrm{C}), 310(25 \mathrm{Cr}$ - $20 \mathrm{Ni}-2 \mathrm{Mn}-0.3 \mathrm{C})$, and Kromarc $58(15 \mathrm{Cr}-21 \mathrm{Ni}-11 \mathrm{Mn}-$ $0.05 \mathrm{C}-0.17 \mathrm{~N}$ ) fall into this class (Fig. 10). Within this class, there is a much smaller variation in fatigue-crack growth rate at a $\Delta K$ range of $30 \mathrm{MPa} \cdot \mathrm{m}^{1 / 2}$, ahout a factor of 2 .

- Some alloys, when tested in the sensitized condition, underwent a change in fracture mode from transgranular to intergranular. This behavior was seen for Nitronic 33 [72] and Type 304LN [39] (see Fig. 15). As shown in Fig. 13, depending on the alloy, sensitization results in behavior ranging from no apparent change in fatigue-crack growth behavior (Type $310 \mathrm{~S}$ ) to a two- to three-times acceleration in

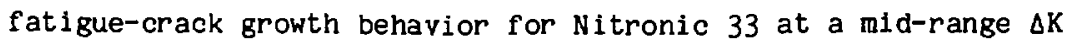
value of $4 \mathrm{C} \mathrm{MPa} \cdot \mathrm{m}^{1 / 2}$. 


\subsubsection{Cast alloys}

Information on cryogenic mechanical properties of austentic stainless steel castings other than Types CF8 (19 Cr - $10 \mathrm{Ni}-1 \mathrm{Mn}-0.05 \mathrm{C}$ ) and CF8M $(19 \mathrm{Cr}-10 \mathrm{Ni}-2.5 \mathrm{Mo}-1 \mathrm{Mn}-0.05 \mathrm{C})$ is very scarce. Available information on $20-K$ and $4-K$ properties (tensile, fracture-toughness, and Impact properties) of Kromarc 55 [73-75] and modified CK-20 [76] are summarized in Table 8. The 20-K and 4-K yield strengths of these cast alloys fall below $690 \mathrm{MPa}$, which place them in the "low-strength" category, as previously discussed for wrought stainless steels.

Considerable $4-K$ mechanical property information was developed in the last few years on alloys CF 3 and CF8M, the cast-product analogs for Type 304 and 316 , respectively. Recourse to the romposition ranges for these casting grades, coupled with use of the Schoefer Dlagram [77-78] (Fig. 16), which is the casting-industry analog of the weldors' Delong diagram for representation of regions of phase stability, indicates that both of these alloys can be manufactured with up to $30 \%$ ferrite.

In Fig. 17, the 4-K yield strengths of CF8 and CF8M castings [79-83] are plotted as a function of carbon and nitrogen content. Although yield strength increases with increasing carbon and nitrogen, similar to wrought single-phase austenitic stainless steels, the large amount of scatter indicates that other factors contribute to the strengthening of these alloys, such as grain-size and the presence of dispersed delta-ferrite. In Fig. 18 we summarize the fracture-toughness information on these castings as a function of yield strength at $4 \mathrm{~K}$. Two types of behavior are seen. 
- Single-phase CF8 and CF8M castings exhibit fracture-toughness and yield-strength performances as good as their wrought counterparts that have similar compositions. Small differences in properties between cast and wrought steels are probably caused by one or more of the following: (1) solidificaticn shrinkage-porosity, (2) greater compositional inhomogenities expected in castings vs wrought alloys, and (3) larger grain sizes in castings as opposed to wrought alloys.

- Duplex austenite plus ferrite CF8 and CF8M castings suffer greatly reduced fracture toughness with increasing yield strength as compared to wrought alloys. Castings of CF8 and CF8M containing about 10 to $15 \%$ delta-ferrite (Fig. 19) suffered $70 \%$ decreases in

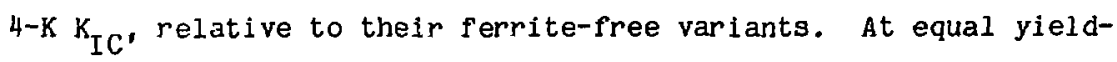
strength levels, about $70 \%$ of this was attributable to the presence of delta-ferrite and the remaining $30 \%$ was attributed to the increased yield strength (Fig. 18). Failure in the duplex castings of boti: grades occurred by cleavage (brittle fracture) of the deltaferrite and was foliuwed by ductile fracture by void coalescence in the surrounding austenite at stresses greater than those needed to crack the ferrite.

In Fig. 19 are also plotted the variations in yield strength with delta-ferrite for CF8 and CF8M castings [78-83). For both alloys, yield-strength increased with increasing delta-ferrite content, the dependence being greater than linear at delta-ferrite contents beyond about $10 \%$ for CF 8 and $20 \%$ for CF8M. In Fig. 20 fracture-toughness and yield strength of CF8M 
castings is plotted as a function of nitrogen content for alloys with an essentialiy constant $(9 \pm 1 \%)$ ferrite content. Note that increasing nitrogen content increases yield strength rapidly, but decreases fracture toughness slowly.

In Fig. 21 is plotted available $4-K$ fatigue-crack growth information for several heats of CF8M castings wth delta-ferrite levels ranging from 1 to $29 \%$ [84-85]. There is a general increase in fatigue-crack growth rate with increasing delta-ferrite content, which is attributed to the occurrence of a "qldasi-cleavage" fracture in the alloys with cast more than 18 ferrite [84].

\section{Fusion welding of austenitic stainless steels}

\subsection{Compositions and microstructures of stainless steel weld metals}

Compositions of welding consumables used to join austenitic stainless steels for cryogenic service are summarized in Table 9 for domestic products [86-91], and in Table 10 for some European and Japanese products [92-103]. Figure 22 is a plot of these welding products on the standard De Long Diagram [15-16], which relates the chemical-composition of the weld metal to the presence or absence of delta-ferrite.

These calculations were carried out as follows:

a. Where a point analysis, rather than a range of composition was given, $\mathrm{E}_{\mathrm{Ni}}$ and $\mathrm{E}_{\mathrm{Cr}}$ for the point analysis were calculated and the point plotted on Fig. 22 . 
b. Where only a "maximum level" of a particular element is stated, a minimum level was assumed to be $25 \%$ of the maximum.

c. Since $N_{2}$ level is not of ten reported, the following convention for $\mathrm{N}_{2}$ leve1s as a function of welding process is used:

\begin{tabular}{lr} 
Process & Assumed $\mathrm{N}_{2}$ \\
\hline SMA & $0.06 \%$ \\
GTA & $0.06 \%$ \\
GMA & $0.08 \%$
\end{tabular}

Examination of Tables 9 and 10 and Fig. 22 show that the domestically produced welding consumables are specifically designed to be used with either the conventional $\mathrm{Cr}-\mathrm{Ni}$ austenitic stainless steels or with the higher strength $\mathrm{Cr}-\mathrm{Mn}-\mathrm{Ni}-\mathrm{N}_{2}$ austenitic stainless steels. Examples of the former class are Types $308(\mathrm{~L})(\mathrm{Fe}-20 \mathrm{Cr}-10 \mathrm{Ni}), 316(\mathrm{~L})(\mathrm{Fe}-17 \mathrm{Cr}-13 \mathrm{Ni}-2 \mathrm{Mo})$, and $310(\mathrm{Fe}-26 \mathrm{Cr}-21 \mathrm{N1}-2 \mathrm{Mn})$. The first two types are used interchanceably with Types 304 and 316 base metals and their carbon and nitrogen variants, while the last type is used to join Type 310 or 310 (low carbon) base metals. Examples of the latter class are Nitronic $35 \mathrm{~W}(\mathrm{Fe}-18 \mathrm{Cr}-12 \mathrm{Mn}-5 \mathrm{Ni}$ ), Nitronic 40W (Fe - $20 \mathrm{Cr}-10 \mathrm{Mn}-7 \mathrm{Ni})$, and Nitronio 50W (Fe - $23 \mathrm{Cr}-$ $6 \mathrm{Mn}-11 \mathrm{Ni}-2 \mathrm{Mo}$ ), used to join the Nitronic 33,40 and 50 base metals, respectively. Generally, as-deposited weld metals of the $308(\mathrm{~L}), " N \mathrm{xx}$ W", and $316(\mathrm{~L})$ types contain 4 to $12 \%$ delta-ferrite at room temperature, which is needed to prevent the formation of sclidification-related defects [11-21, 104107!, referred to as "microfissures" or "hot cracks".

The reason for concern about the composition of a specific weld metal is that two of the design constraints, low magnetic permeability and high. 
cryogenic ir racture-toughness, imposed by the need not to perturb the plasma and to maintain a high level of resistance to brittle fracture at $4 \mathrm{~K}$, are most easily achieved by use of welding-consumables that result in a weld deposit free of ferrite. Fjarp 23 presents a correlation [108] weon magnetic permeability, $\mu$, and the amount of ferromagnetic phase in the weld. Figure 24 presents a picit of cryog nic plane-strain frasture toughness, $\mathrm{K}_{\text {IC' }}$ as a function of the amount of ferrite in carefully made shielded metal arc rilds, using Type 316L filler metal [109]. Note tr.at ferrite additions to levels of 4 to $12 \%$, the levels commonly found in most stainless steel welds, results in the following changes:

- Perhability increases of about 1.20 to 2.10 , a $45 \%$ increase.

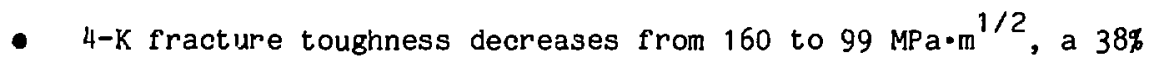
decrease.

\subsection{Solidification-induced defects in austenitic stalnless steel weld metais}

On cooling from the liquid to the solid state after welding, two closely related types of solidification-related defects can occur in austenitic stainless steel weld metals [110]:

(1) "Hot Cracks", which ara gross separations along interdendritic (solidification-structure) boundaries. These derects are large enough to be seen with the naked eye and usually result in the assembly either undergoing extenslve repair or being discarded. 
(2) "Microfissures", which are very small separations along interdendritic boundaries. These defects are typicaily [111] 0.005 to $0.020 \mathrm{in.}$ long, and are impossible to detect by nondestructive examination. Their danger lies in their growing under cyclic applied stresses, typical of the condition seen in operation of mirror or tokamak magnets.

Recently, several groups of researchers $[102,111-124]$ developed the following explanation of why some delta-ferrite must be present to prevent cracking at elevated temperatures during and just after the solidification of nominally "austenitic" stainless steel weld metals. As the level of ferrite stabilizers, such as $\mathrm{Cr}$, increase or level of austenite stabilizers, such as $\mathrm{Ni}$, decrease (see Fig. 24), the primary phase formed on solidification of a weld varies as follows:

(1) Austenite is the only solid phase formed, and no further high-temperature metallurgical reactions occur on rapid cooing of the weld metal to room temperature (Fig. 25a).

(2) Austenite forms as the primary phase. A small amount of deltaferrite forms on solidification of the impurity-enriched, interdendritic liquid (Fig. 25b).

(3) Delta-ferrite forms as the primary phase. A moderate amount of austenite forms on solidification of the impurity-enriched, interdendritic liquid. On cooling of the just solidified weld metal to point 1 on Fig. 24, the delta-ferrite transforms to austenite, the transformation being complete as the cooling weld bead passes 
point 2 on Fig. 24. The resulting microstructure is shown schematically in Figs. $25 \mathrm{c}$ and $25 \mathrm{~d}$.

(4) Delta-ferrite is the only solid phase formed as the weld metal solidifies, and part of it transforms to austenite on cooling towards room temperature. The resulting microstructure is shown Jchematically lis Fig. 25e.

All fusion-welding processes involve separation of various alloy additions (Cr, Ni, Mn, Mo, C, $\mathrm{N}_{2}$ ) and of tramp elements (Si, F, S) introduced during the manufacture of steel to one or more of the phases; liquid, austenite, and/or ferrite. In stainless steel welds, $\mathrm{Cr}$ is rejected to the liquid during solidification of austenite as the primary phase (Fig. 25a-b), and $\mathrm{Ni}$ is rejected to the liquid during solidification or ferrite as the primary phase (Fig. 25c-€).

Elements such as $\mathrm{Si}, \mathrm{S}, \mathrm{P}$, and Mo, which have high solubilities in delta-ferrite, are rejected to the liquid during solidification of austenite as the primary phase. Elements which have high solubilities in austenite, such as $\mathrm{Cr}, \mathrm{N}_{2}$ and $\mathrm{Mn}$, are rejected to the liquid during solidification of ferrite as the primary phase.

Phosphorus and sulfur form low-melting-point alloys between phosphides and sulfides, while Si tends to form a glassy silicate film, such as $\mathrm{MSiO}_{4}$ where $\mathrm{M}$ may be $\mathrm{Cr}, \mathrm{Fe}, \mathrm{Ni}, \mathrm{Mn}$ and/or $\mathrm{Mo}$. Such low-melting-point nonmetallic phases will remain liquid, long after the bulk of the weld has solidified. In the case of alloys with solidified austenite as the primary phase, $S, P$, and Si are rejected to the liquid. There they form in the interdendritic regions the above described low-melting-point phases which are the last to solidify. 
Once the bulk of the weld is solid, any attempt to transfer deformations induced by thermal contraction or other sources, such as the weight of the structure, results in the necessary accommodation-deformations being concentrated in regions that are unable to sustain relative motion, i.e., the solute-enriched low-melting point interdendritic liquids. This results in the formation of cracks as the liquid flows away from the locations under load. Alloys that solidify with delta-ferrite as the primary phase reject lesser amounts of these elements $(P, S$, and $S i)$ to the liquid, the result being little or no formation of the low-melting-point nonmetallic phases. Therefore, these alloys are much more resistant to the formation of microfissures and hot cracks.

The probable effect of component size, especially increasing section thickness, on the hot cracking and microfissuring behavior of stainless steel weld metals is to provide an increcingly rigid restraining mass around the partially molten weld metal. Also increasing amsunts of accommodationdeformation must be taken up by the partially molten weld metal. Hence, weld metals that were borderline with respect to microfissuring and/or hot cracking at a given section thickness are expected to become increasingly prone to cracking as the section size increases.

In practice, it has been long recognized that austenitic stainless steel welds are susceptible to cracking in the fusion zone (weld metal) of singlepass welds [125-129], in the heat-affected zone of the base metal $[126,130-$ 157] and in the heat-affected zones of weld metal produced by thermal cycles induced by subsequent welds in multipass joints $[124,130-131,138-140]$.

Cracking in single-pass welds may be dealt with by reducing the level of residual stress in the weld joint (known as "restraint") and by adjustment of the composition of the welding consumable (electrode, bare wire plus shielding 
gas, or wire plus flux) to assure the presence of some ferrite in the weld after cooling to room temperature. Cracking in the base-metal heat-affected zone occurs almost exclusively in the Nb-stabilized Type 347 (Fe - $18 \mathrm{Cr}-$ $12 \mathrm{Ni}-0.05 \mathrm{C})$ grade and has become less of a problem in recent years because of improved tramp-element control and improvements in thermonechanical processing of the base plate.

Cracking in multipass welds in austenitic stainless steels is of increasing importance in the Magnetic Fusion Energy program because of the need to use heavy-section (up to 127-mm thick) stainless steel welds in the manufacture of increasingly larger superconducting magnet structures. General agreement exists aroung welding researchers that cracking in multipass welds occurs in the heat-affected zone of the weld metal resulting from the thermal cycles of subsequent weld passes [124,140-149]. Composition control of the deposited weld metal, which ultimately results in delta-ferrite in the room temperature microstructure, can suppress this cracking.

Several studies [144-146] that employed actual production welds of Type 316 stainless steel ( $\mathrm{Fe}-17 \mathrm{Cr}-13 \mathrm{Ni}-2 \mathrm{Mo}-2 \mathrm{Mn}-0.06 \mathrm{C}$ ) found neither cracking in the base-metal heat-affected zones nor in the last or cover passes in the weld metal. However, many small cracks, called "microfissures", were found in the interior of these welds, all. in heat-affected zones of subsequently deposited weld beads. These observations were recently confirmed by investigations on various austenitic stainless steel weld metals, using the fissure bend test $[20,120,148-149]$.

Hadrill and Baker [140] and Honeycombe and Gooch [106,141-143], in studying rypes 310 and 316 weld metals, found that fully austenitic ferrite-free stainless steel weld metals contained extensive microfissuring. In multipass welds, these researchers found that the microfissuring was 
concentrated in the heat-affected zones of previously made weld passes. Microfissures seldom were seen in weld passes not subsequently subjected to additional weld thermal cycles. These observations confirm the work of the researchers just cited [106,140-142]. Most recent work published on formation of weld defects in multipass, heavy-section welds in austenitic stainless steels $[20,107,124,140,144-147,149]$ identified the location of the microfissures just described and agreed that:

- Fissures occur along grain boundaries regardless of whether they are located in the base-metal heat-affected zone, weld-metal heataffected zone, or in weld passes only slightly affected by subsequent weld passes.

- Weld-metal heat-affected zones produced by subsequent weld passes in thick, multipass welds are the preferred site for formation of fissures.

- Fissures are formed at elevated temperatures, above about $1144 \mathrm{~K}$, and may result from more than a single cracking mechanism, such as liquation-cracking when some solute-laden grain boundaries are still molten, followed by failure of embrittled grain boundaries in the "hazard heat-affected zone" [124].

- The tendency toward fissure formation decreases when the room-temperature weld-metal microstructure contains some deltaferrite. 


\subsection{Evaluation of Austenitic Stainless Steel Weld Metals for Fissuring}

Tendencies

Numerous types of weldability tests may be used to evaluate the microfissuring tendencies of a weld metal. Such tests include the circular-groove test [128], fisco test [150a], murex hot-crack test [151], case pin hot-tear test $[13,152]$, hot-ductility test [153], varistraint test $[111,113,128-129,150]$, fissure-bend test $[124,14 ;-148, i 54-155]$ and P.V.R. test [148]. Most domestic [142,155] and some foreign [147-148] welding consumables for joining austenitic stainless steel have been evaluated for microfissuring tendencies by the fissure-bend test. The results of these tests, summarized in Fig. 26, indicate the following:

- The microfissuring tendency (worst to best) for U.S.A.-supplied welding consumables deposited by the shielded metal arc (SMA) process is Type 347 (worst), Type 318, Type 309, Type 308L, Type 316. Type 308, Type 316L, and Type $[16 \mathrm{cr}-8 \mathrm{Ni}-2 \mathrm{Mo}]$ (best).

- The presence of 0.5 to $0.7 \% \mathrm{Nb}$, usually added to suppress intergranular carbonitride formation which can cause low-temperature embrittlement in stainless steel weld metals, rendered both weldmetal Types $347[18 \mathrm{Cr}-12 \mathrm{Ni}-0.6 \mathrm{Nb}-0.06 \mathrm{C}]$ and $318[17 \mathrm{Cr}-$ $12 \mathrm{Ni}-0.5 \mathrm{Nb}-0.06 \mathrm{c}]$ extremely prone to microfissuring.

- Consistent production of microfissure-free welds without the presence of ferrite is quite difficult to achieve. However, microfissure-free welds made with higher than usual levels of Mn and 
$\mathrm{Mo}$, in the range of 3 to $7 \%$ each, and a ferrite level of at least $1 \%$ appear to be consistently achievable. Several commercially available European welding consumables, such as Avesta's 832SKR-LF and $P-6$, and A. Johnson's 2RM69 (all in Table 10), as well as Bohler Brothers Alloy "F", fall in this category.

- The nature of the welding process has an effect on the occurrence and extent if microfissuring over and above that imparted by a change in welding consumable. Type 310 weld metal microfissured extensively ( 53 fissures) when deposited by the SMA process and only slightly ( 5 fissures) when deposited by the GTA (gas-tungsten arc) process.

\subsection{Mechanical properties of weld metals at cryogenic temperatures}

Figures 27 and 28 summarize $4-K$ fracture-toughness data for many stainless steel welds made by various processes $[71,76,97,109,156,161]$ in the form of plane-strain fracture toughness vs yield strength plots. Also shown on these figures is the base-metal trend line from Fig. 7. Examination of Figs. 27 and 28 indicates that, in general, the usual inverse relationship between fracture toughness and yield strergth prevails. Specific comments follow:

(1) Use of the shielded-metal arc (SMA) process with either 308L electrodes can produce welds with yield strength in the range of 690 to $932 \mathrm{MPa}$ with corresponding plane-strain fracture-toughness values varying over a wide range ( 88 to $204 \mathrm{MPa} \cdot \mathrm{m}^{1 / 2}$ ). Considerable 
improvement in the plane-strain fracture toughness of SMA welds deposited with E316L-15 electrodes could also be attained by use of interpass peening with or without a final post-weld annealing treatment [158-159].

(2) Use of high deposition-rate welding processes, such as submerged arc weld (SAW) [158-159] or flux-cored metal arc (FCMA) [159-161] with both Types 308L and 316L welding consumables, produced welds with much lower plane-strain fracture-toughness values, typically 66 to $132 \mathrm{MPa} \cdot \mathrm{m}^{1 / 2}$, than was seen for the SMA welds made with the same filler metals.

(3) At weld-metal yield strengths above $1035 \mathrm{MPa}$, the corresponding plane-strain fracture-toughness values fell in the 82 to 154 $M P a \cdot m^{1 / 2}[109,158]$.

(4) The highest combinations of plane-strain fracture toughness and yield strength occurred in SMA and SAW welds: $259 \mathrm{MPa} \cdot \mathrm{m}^{1 / 2}$ fracture-toughness and $1628 \mathrm{MPa}$ yield strength for the SMA weld made with the Bohler Brothers $[\mathrm{Fe}-19.5 \mathrm{Cr}-15.5 \mathrm{Ni}-4 \mathrm{Mn}-2 \mathrm{Mo}-$ $0.02 \mathrm{C}$ ] electrode [159]; and $159 \mathrm{MPa} \cdot \mathrm{m}^{1 / 2}$ fracture-toughness at 1118 MPa yield-strength for the SAW weld made with Paton Institutes "2016-6" filler wire [Fe - $20 \mathrm{Cr}-16 \mathrm{Ni}-6 \mathrm{Mn}-0.2 \mathrm{~N}_{2}-0.06$ ] [97]. This latter material is said to fall within the range of coverage of an Armco Steel Company patent [162]. 
The general effect of increasing amounts of ferrite on the $4-K$ plane-strain fracture toughness of stainless steel weld metals is to decrease the fracture-toughness, as shown in Figs. 4 and $29[107,158-159,161-163]$. However, the large amount of variation in the plane-strain fracture-toughness values of these welds indicates that the ferrite content alone is not the only important factor in the degradation of $4-K$ fracture toughness. Whipple and Brown [83] demonstrated that the amount and distribution of ferrite in ferrite-containing austenitic stainless steel weld metals and castings exerts a profound effect on path of the fracture and, presumably, on the measured fracture-toughness values. The inherently rapid solidification rates and cooling rates in weldment produce a highly-directional solidification pattern and a relatively fine, cellular-dendritic microstructure with the deltaferrite closely associated with the original solidification pattern. Since crack growth during fracture-toughness testing is usually associated with cracking of the residual delta-ferrite, any factor that results in a coricinuous network of delta-ferrite along dendrite-boundaries will provide a preferred cracking path and lower toughness that would be expected for a weld (or casting) of the same amount of delta-ferrite distributed in a discont inuous morphology.

Recent work by Szumachowski and Reid $[22,164]$ and Marshall and Farrar [165] on the factors that affect the 77-K toughness of SMA stainless steel weld metals indicate that optimum $77-\mathrm{K}$ impact resistance may be achieved by using SMA welding consumables and welding conditions that produce welds with the following: 
- No ferrite or other distributed second phase that can act either as a preferred site for void-nucleation or as a preferential continuous path for crack propagation.

- Low carbon, less than $0.04 \%$.

- Low $\mathrm{N}_{2}$ and $\mathrm{O}_{2}$, less than $0.05 \%$ each.

- High in nickel, "as high as possible".

- A basic, fluospar-lime (-15) electrode coating.

- Low $S$ and $P$, less than $0.05 \%$ for each element to limit occurrence of dispersed, brittle, second-phase particles that can act as preferred sites for void nucleation.

Unfortunately $[107,158-159,163]$, there is no universal, clear-cut, correlation between the parameters measured in the impact testing of stainless steel weld metals at $77-\mathrm{K}$ and the $4-\mathrm{K}$ plane-strain fracture toughness of these weld metals. However, individual correlations between $4-K$ fracture toughness and $77-\mathrm{K}$ energy absorption in the Charpy $\mathrm{V}$-notch impact test have been seen [107,158-159,161] in specific weld series runs with welding consumable, joint design, and other welding parameters nominally fixed.

Available $4-K$ fatigue-crack growth information on various stainless steel weld metals is presented in Figs. 30 to $31[71,146-i 48,166]$. Consider first the performance of Type $316 \mathrm{~L}$ weld metal deposited by either the SMA or SAW processes (Fig. 30). Neither weld process nor ferrite level ( $8 \%$ in the SAW weld, 0 to $1 \%$ in the SMA welds) appeared to influence the fatigue-crack growth 
performance. Only the combination of interpass peening plus a post-weld annealing treatment [158] performed on the SMA weld reduced the fatigue-crack growth rate by a factor of 2 to 2.5 at higher WK levels from the "as welded" data (Fig. 30). This insensitivity in the Paris regime of fatigue-crack growth rate to metallurgical factors is normal; a factor of 2 scatter is common for fatigue-crack growth rate determined on the same material by the same test laboratory [167].

In Fig. 31 the three most resistant weld metals to fatigue-crack growth are GMA-deposited $[18 \mathrm{Cr}-16 \mathrm{NI}-9 \mathrm{Mn}]$, GTA deposited Kromarc 58 [Fe - $16 \mathrm{Cr}$ - $20 \mathrm{NI}-11 \mathrm{Mn}-2.25 \mathrm{Mo}-0.05 \mathrm{C}]$ and SMA-deposited Type 310. All are microstructurally stable when tested at $4 \mathrm{~K}$. The other four weld metals consist of three lots of Type 308L, two being deposited by the FCMA process, one by the SMA process, and one lot of GTA-deposited Nitronic $40 \mathrm{~W}[\mathrm{Fe}-20 \mathrm{Cr}$ $\left.-7 \mathrm{Ni}-9.5 \mathrm{Mn}-0.3 \mathrm{~N}_{2}-0.02 \mathrm{C}\right]$. These four weld metals are microstructurally unstable in that they undergo transformation to either $\alpha^{\prime-}$ or $\varepsilon$-martensite during testing at $4 \mathrm{~K}[60,168]$. This results in decreased resistance to fracture near the tip of the growing fatigue crack and in faster fatigue-crack growth.

Figure 32 compares the fatigue-crack-growth behavior of miorostructurally stable and unstable weld metals. Note that the microstructurally-stable weld metals exhibit fatigue-crack-growth rates of one-fourth to one-third of that of the mlcrostructurally-unstable weld metals at a $\Delta K$ range of $33 \mathrm{MPa} \cdot \mathrm{m}^{1 / 2}$. As the stress-intensity range increases, some overlap in performance of the two classes of weld metals is seen (Fig. 32), but the unstable weld metals still have much righer maximum fatigue-crack growth rates than the stable weld metals. This relationship between the fatigue-crack growth rates of 
microstructurally unstable and of stable weld-metals is qualitatively similar to that seen for the same two classes of base metals (Fig, 14 ).

\section{D1scussion}

A perennial argument raised against the use of welds and castings in highly-loaded structures is that they have inferior mechanical properties as compared to their wrought counterparts such as plate. For austenitic stainless steels intended for 4-K service, it is appropriate to examine this thesis in the case of two classes of steels: first, for comr !ately austenitic plate versus completely austenitic castings and welds and, second, for completely austenitic plate versus ferrite-containing castings and welds. Consider the comparisons presented in Table 11.

(1) Completely austenitic products. Two distinctly different types of behavior are seen for Type 310 stainless steel. The weld and plate have comparable yield strengths ( $810 \mathrm{MPa}$ vs $790 \mathrm{MPa}$ ) but a factor of 2 difference in fracture toughness, about $120 \mathrm{MPa} \cdot \mathrm{m}^{1 / 2}$ for the SMA weld versus about $240 \mathrm{MPa} \cdot \mathrm{m}^{1 / 2}$ for the plate. However, for the [Paton Institute "20-16-6" alloy] the plate (1150 MPa) and weld (1000 to $1200 \mathrm{MPa}$ ) have comparable yield strengths, but the weld's coughness ( 150 to $208 \mathrm{MPa} \cdot \mathrm{m}^{1 / 2}$ ) is about $39 \%$ higher than that of the plate.

(2) Completely austenitic plate versus ferrite-containing weld metal and castings. The behavior here is as one would expect. For wrought Type 304LN plate compared with Type 316L weld metal and CF8M 
castings, at comparable yield strengths of $600 \pm 40$ to $880 \pm 20 \mathrm{MPa}$, the average fracture toughness values for the welds and castings were $50 \pm 5 \%$ of that for the wrought plate. So, it is appropriate to have concern about the cryogenic mechanical propertisa of welds and castings if they contain delta-ferrite.

\section{Closure}

Many austenitic stainless steels, both standard and special grades, are suitable for use in load-bearing applications in superconducting magnet systems and for cryogen-handling and storage systems and for other uses that involve operation at $4 \mathrm{~K}$ to $77 \mathrm{~K}$. For most common grades of wrought alloys, such as Type 304 and 316 and their low-carbon high-nitrogen variants, necessary information exists to permit compositional optimization, materia: selection, and design analysis for fracture-critical applications, using a "leak-before-break" design philosophy, supplemented by fracture-mechanics analyses.

A similar situation exists with respect to the two most commonly used weld metals, Type 308L and Type 316L. However, we must recognize that much remains to be learned about optimizing the amount and distribution of ferrite in the weld metal to permit attainment of the seemingly mutually-exclusive goals of freedom from weld-cracking or microfissures, of minimum magnetic permeability, and of attaining useful combinations of yield strength and fracture toughness. All of these must be attained using welding processes that deposit weld metal economically in both shop and fleld fabrications.

We find a similar situation with Types CF8 and CF8M castings. The basic $K_{I C}: \sigma_{y}$ trade offs for these cast grades are similar to those encountered with 
Types $308 \mathrm{~L}$ and $316 \mathrm{~L}$ weld metals. However, results for these castings were generated on carefully processed small castings, with special care being exerted to maintain high quality and freedom from microshrinkage and other common casting-related defects. Whether these property levels can be reliably reproduced on large cast parts must be demonstrated by evaluation of the latter's cryogenic mechanical properties.

In closing, it is the opinion of the authors that while a level of information exists that is "necessary" for the design and fabrication of austenitic stainless steel structures for $4-K$ operation, the absence of any extensive systematic body of operating history (such as exists for the Power Boiler and Pressure Vessel industries) renders premature the idea that the prasent body of knowledge assembled in this paper is "sufficient" to support the generation of handbook-based designs.

\section{Acknowledgments}

We would like to acknowledge those who have supplied us with unpubiished information during the preparation of this report, in particular: R. P. Reed, D. T. Read, H. I. McHenry, and R. Tobler of the National Bureau of Standards; E. L. Brown of Colorado School of Mines; and I. A. Horvath of Convair Division of General Dynamics Corporation. Helpful discussions and contributions of C. [. Henning (LLNL), J. W. Morris, Jr. (LBL), and R. D. Streit (LLNL) are also acknowledged. 
References

[1] Z. J. J. Stekly, plenary speech, 1983 Internat. Cryogenic Engrg. Conf., Colorado Springs, Co, Aug. 1983.

[2] J. F. Clarke, in: Proc. ASM-DOE Conf. on Materials Needs for Advanced Energy Systems, Washington, D.C., 1984, to appear.

[3] R. W. Conn, Scientif1c American 249(4) (1983) 60.

[4] C. D. Henning, in: Proc. 9th Intern. Cryogenic Engrg. Conf., eds. K. Yasukochi and H. Nagano (Butterworths, London, 1982) p. 7.

[5] C. D. Henning and B. G. Logan, A Tokamak ignition/burn experimental research device, Sixth Topical Meeting on the Technology of Fusion Energy, San Francisco, March 1985, Paper 5C2-13.

[6] B. Blackwell, M. Greenwald, D. Gwinn, B. Lipschultz, E. Marmar, D. B. Montgomery, R. Parker, P. Politzer, M. Porkolab, J. Schultz, and S. Wolfe, Alcator DCT proposal, Plasma Fusion Center, M.I.T., (September 1983).

[7] C. D. Henning, A. J. Hodges, J. H. Van Sant, R. E. Hinkle, J. A. Horvath, R. E. Hintz, E. Dalder, R. Baldi, and R. Tatro, in: Proc. 8th Symp. Engrg. Problems of Fusion Research (San Francisco, November 1979) p. 84 . 


$$
-41-
$$

[8] J. File, R. G. Mills, G. V. Sheffield, "Large superconducting magnet designs for fusion reactors," IEEE Trans. On Nuclear Science NS-18 $(1971), 205-207$.

[9] C. D. Henning, Method for making baseball seam magnetic coils, U.S. Patent No. 3465431.

[10] K. R. Johnson, A. Liu and K. E. Ryan, Instruction manual for crack propagation predictive analysis computer program "FLAGRO" Release 2, Rockwell International Corp., Space Division (April 1975).

[11] F. C. Hull, Welding Journal 52(5) (1973) pp. 193s-203s.

[12] G. C. Curtis and J. Sherwin, British Journal of Applied Physics 12 (1961) $344-345$.

[13] F. C. Hull, Welding Journal 46(9) (1967) pp. 399s-409s.

[14] Welding Engineer 58(2) (1973) 27-30.

[15] W. T. DeLong, Welding Journal 52(2) (1973) pp. 69s-72s.

[16] i'. F. Reid and W. T. DeLong, Metals Progress 104(1) (1973) 73-77.

[17] C. J. Long and W. T. DeLong, Welding Journal 52(7) (1973) pp. $281 \mathrm{~s}-297 \mathrm{~s}$. 
[18] W. T. Delong, Welding Journal 53(7) (1974) pp. 273s-286s.

[19] P. G. McDougall, Welding Research Abroad, XXI(7) (1974) 2-7.

[20] C. D. Lundin, W. T. DeLong, and D. F. Spond, Welding Journal 54(8) (1975) pp. $241 \mathrm{~s}-246 \mathrm{~s}$.

[21] H. C. Campbell, Welding Journal 54(12) (1975) 867-871.

[22] E. Szumachowski and H. F. Reld, Welding Journal 57(10) (1978) p. $325 s$.

[23] D. T. Read, National Bureau of Standards, personal cominunication, Boulder, CO, June 20, 1978.

[24] D. C. Hilty and T. F. Kaveny, in: Handbook of Stainless Steels, eds. D. Peckner and M. Bernstein (MoGraw-Hill, New York) Chapt. 3, pp. $3-1$ to $3-37$.

[25] E, Dalder, Lawrence Livermore National Laboratory, unpublished data, October 1979.

[26] J. D. DeFillippi, K. G. Brickner, and E. M. Gilbert, Transactions AIME 245(10) (1969) 2141-2148.

[27] R. P. Reed, Acta Metallurgica 10 (1962) 865. 
[28] R. P. Reed, R. L. Durcholz, R. E. Schramm, and T. C. Patrician, NBS Technical Note 609 (August 1971).

[29] R. P. Reed and J. F. Breedis, in "Behavior of Materials at Cryogenic Temperatures," ASTM, Philadelphia, PA, ASTM STP-387 (1965) pp. 60-132.

[30] R. P. Reed and R. P. Mikesell, in: Proc. 1958 Conf. on Cryogenic Engrg., ed. M. D. Timmerhaus (1958) pp. 84-100.

[31] C. J. Gunter and R. P. Reed, Transactions AIME 230(12) (1964) $1713-1720$.

[32] D. C. Larbalestier and H. W. King, Cryogenics 13(3) (1973) 160-168.

[33] D. V. Neff, T. E. Mitchell, and A. R. Troiano, Transactions ASM 62 (1969) 858-868.

[34] F. W. Schaller and V. F. Zackay, Transactions ASM 51 (1959) 609-628.

[35] A. J. Nachtigall, NASA TM-X 52703 (October 1969).

[36] J. J. Eckenrod and C. W. Kovach, Metals Engineering Quarterly 12(1) (1972) 5-10.

[37] A. Randak, W. Wessiling, H. Bock, H. Steinmaurer, and L. Faust, Stahl and Eisen $91(22)(1970)$ 1255-1270. 
[38] R. P. Reed, Martensitic transformations in Fe-Cr-Ni stainless steels, in Austenitic Stainless Steels at Low Temperatures, eds. R. P. Reed and T. Horłuchi (Plenum, New York, 1983) pp. 41-67.

[39] E. N. C. Dalder, unpublished results, Lawrence Livermore National Laboratory, 1984.

[40] See, for example, J. D. Landes and J. A. Begley, ASTM Special Technical Publication 560 (1974) 170-179.

[41] E. N. C. Dalder, Standard practice for fracture tesisng of stainless steels at cryogenic temperatures, Appendix B to MEL83-001675, Lawrence Livermore National Laboratory (April 1983) pp. 20-26.

[42] J. A. Shepic, Fatigue testing of stainless steels, in: Materials Studies for Magnetic Eusion Energy Applications at Low Temperatures-I, NBS IR 78-884 (April 1978) pp. 15-68.

[43] D. T. Read and R. P. Reed, Fatigue and fracture properties of selected austenitic stainless steels at cryogenic temperature," in: Materials Studies for Magnetic Fusion Energy Applications at Low Temperatures-I, NBS IR 79-1609 (June 1979) pp. 81-122.

[44] J. S. H. Ross and D. A. Smith, Superconducting ac generators, soine recent experimental investigations, in: Proc. 8 th Intern. Conf Cryogenic Materials (London, July 1978). 
[45] Handbook on Materials for Superconducting Machinery, MCIC HB-04, including first and second supplements (January 1977).

[46] W. Dobson and D. Johnson, Effect of strain rate on measured mechanical properties of stainless steel at $4 \mathrm{~K}$, Adv. Cryog. Engrg. 30 (1983) 185-192.

[47] H. I. MoHenry, The properties of austenitic stainless steel at cryogenic temperatures, in: Austenitic Stainless Steel at Low Temperatures, eds. R. P. Read and T. Horluchi (Plenum Press, New York, 1983) pp. 1-28.

[48] H. Krauth and A. Nyilas, Toughness and fatigue properties of austenitic steels at cryogenic temperatures and their application in complex structures, in: Austenitic Stainless Steel at Low Temperatures, eds. R. P. Read and T. Horiuchi (Plenum Press, New York, 1983) pp. 159-170.

[49] R. P. Read and N. Simon, Low temperature strengthening of austenitic stainless steels with nitrogen and carbon, Adv. Cryog. Engrg. 30 (1983) $127-136$.

[50] R. P. Reed and R. L. Tobler, Deformation of metastable austenitic steels at low temperatures, Adv. Cryog. Eng. 28 (1981) pp. 49-56. 
[51] Y. Takahashi, K. Yoshida, M. Shimada, E. Tada, R. Miura, and S. Shimamoto, Mechanical evaluation of nitrogen-strengthened stainless steels at $4 \mathrm{~K}, \mathrm{Adv}$. Cryog. Engrg. 28 (1981) 73-81.

[52] R. L. Tobler and R. P. Reed, Tensile and fracture properties of modified AISI Type 304 stalnless steel, Adv. Cryog. Engrg. 28 (1981) 83-92.

[53] F. N. Mazandarany, D. M. Parker, R. F. Koenig, and D. T. Read, A nitrogen-strengthened austentic stainless steel for cryogenic magnet structures, Adv. Cryog. Engrg. 26 (1979) 158-170.

[54] J. Wells, Kossowsky, W. Logsdon, and M. Daniel, Structural materials for cryogenic applications, in: Materials Research for Superconducting Machinery VI (October 9, 1976).

[55] C. W. Koontz, Eastmet Corporation, personal communication, October 1978.

[56] J. L. Christian, General Dynamics-Convair, personal communication, October 1978.

[57] D. T. Read and R. P. Reed, Toughness, fatigue crack growth, and tensile properties of three nitrogen-strengthened stainless steels at cryogenic temperatures, In: Materials Studies for Magnetic Fusion Energy Applications at Low Temperatures-I, NBSIR 78-88 (April 1978) pp. 93-154. 
[58] P. R. Landon, Studies of the nitrogen-stabilized $21 \mathrm{Cr}-6 \mathrm{Ni}-9 \mathrm{Mn}$ stainless steel, Lawrence Livermore National Laboratory, NBS/ERDA Workshop on Materlals at Low Temperatures, October 1978 .

[59] F. N. Schwartzberg and T. F. Kiefer, Study of fracture behavior of met lo for superconducting applications, in: Materials Research for Superconducting Machinery - Semi-Annual Technical Report IV, National Bureau of Standards, Boulder, co (1975).

[60] A. J. Nachtigall, Strain cycling fatigue behavior of ten structural metals tested in liquid helium, in liquid nitrogen, and in ambient air, NASA TN-D-7532 (February 1974).

[61] A. J. Nachtigall, S. J. Klima, and J. C. Freche, Fatigue of liquid rocket engine materials at cryogenic temperatures to $-452^{\circ} \mathrm{F}$, NASA TN-D-4274 (December 1967).

[62] A-cell, transition, and solenoid coils, Request for Proposal, Lawrence Livermore Laboratory, Appendix A, Section 5.3.8 (June 1980).

[63] G. E. Dieter, Mechanical Metallurgy, (McGraw-Hill, Second Edition, New York, 1976) pp. 422-423. 
[64] R. L. Tobler and R. P. Reed, Fatigue crack growth rates of structural alloys at $4 \mathrm{~K}$, in Materials Research ir. Jupport of Superconducting Machinery - IV, National Bureau of Standards, Boulder, co (October 1975).

[65] J. M. Wells, R. Kossowsky, W. A. Logsdon, and M. R. Daniel, Structural materials for cryogenic applications, in Materials Research in Support of Superconduct!ng Machinery-III, National Bureau of Standards, Boulder, Co (Apr 1l 1975).

[66] F. R. Schwartzberg and T. Kiefer, "Study of fracture kahavior of metals for superconducting applications, in: Materials Research in Support of Superconducting Machinery-III, National Bureau of Standards, Boulder, Co (April 1975).

[67] J. Will, Parent metal propertles verification, General Dynamics-Convair, Report No. 9120113-032 (December 1978).

[68] R. W. Baldi et al., Structural analysis interpretation task for the magnet system for mirror fusion test facility (MFTF), General Dynamics-Convair, Report No. CASD-LLL-79-005, (November 1979) p. $2-2$. 
[69] R. L. Tobler and R. P. Reed, Interstitial carbon and nitrogen effects on the tensile and fracture properties of AISI 304 stainless steels, in: Materials Studies for Magnetic Fusion Energy Applications at Low Temperatures-III, National Bureau of Standards, Boulder, CO (February 1980) pp. 17-48.

[70] D. T. Read and R. P. Reed, Toughness, fatigue crack growth, and tensile properties of three nitrogen-strengthened st:inless steels at cryogenic temperatures," in: Materials Studies for Magnetic Fusion Energy Applications at Low Temperatures-I, National Bureau of Standards, Boulder, CO, NBSIR-78-884 (April 1978) pp. 93-154.

[71] R. L. Tobler, H. I. McHenry, and R. P. Reed, Fracture mechanics parameters for an Fe - 13\% Cr - 19\% Mn stainless steel and its welds at cryogenic temperatures, Adv. Cryog. Engrg. 24 (1978) 560-572.

[72] R. L. Tobler, "Fatigue crack growth in sensitized Fe $-18 \mathrm{Cr}-13 \mathrm{Mn}$ - $3 \mathrm{Ni}-0.37 \mathrm{~N}$ austenitic stainless steel: the significance of micro-mechanisms, in: Materials Studies for Magnetic Fusion Energy Applications at Low Temperatures - VII, National Bureau of Standards, Boulder, CO, NBS IR 84-300 (May 1984) pp. 85-101.

[73] A. B. Miller, An austenitic cast steel for low temperature applications, Cryogenics 5 (December 1965) 320-324. 
[74] F. C. Hull and J. M. Ripper, Discussion to paper by E. R. Hall, in: Symp. on Metallic Materials for Low Temperature Service, ASTM STP 302 (1961) pp. 93-94.

[75] C. L. Goodzeit, Evaluation of stainless steel casting alloys for cryogenic service in the 80-in. 11quid-hydrogen bubble chamber, Adv. Cryog. Engrg. 10A (1965) 26-36.

[76] L. Genens, S-T Wang, S. H. Kim, and E. Brown, Design and fabrication of the cold bore tube for a large superconducting CFFF MHD magnet, 1980 Superconducting MHD Magnet Design Conf., March 1980.

[r7] F. H. Beck, E. A. Schoefer, J. W. Flowers, and M. G. Fontana, New cast high strength alloy grades by structure control, in: Adv. in the Technology of Stainless Steels and Related Alloys, ASTM STP 369, ASTM, Philadelphia, PA (1965), pp. 159-174.

[78] L. J. Schwartzendruber, L. H. Bennett, E. A. Schoefer, W. T. DeLong, and H. C. Campbell, Mossabauer-effect examination of ferrite in stainless steel welds and castings, Welding Journal 53(1) (1974) $1-4$.

[79] K. S. Lee and Den-Hughes, The Effect of delta-ferrite upon the low temperature mechanical properties of centrifugally-cast stainless steels, in: Austenitic Stainless Steels at Low Temperatures, eds. R. P. Reed and T. Horiuch1, (Plenum Press, New York, 1983) pp. 221-242. 
[80] T. A. Whipple and H. I. McHenry, The mechanical properties of stainless steel castings at $4 \mathrm{~K}$, in: Austenitic Stainless steeiz at Low Temperatures, eds. R. P. Reed and T. Horiuchi (Plenum Press, New York, 1983) pp. 243-248.

[81] D. Dew-Hughes and K. S. Lee, The choice of steel for the Isabells magnet tubes, Adv. Cryog. Engr. 26 (1981) 151-157.

[82] E. L. Brown, T. A. Whipple, and R. L. Tobler, Fracture toughness of CF8 castings at $4 \mathrm{~K}$, Metallurgical Transactions A $14 \mathrm{~A}$ (June 1983) $1179-1188$.

[83] T. A. Whipple and E. L. Brown, Deformation and fracture of stainless steel castings and weldments at $4 \mathrm{~K}$, in: Trends in Welding Research in the United States, ed. S. A. David (ASM, Cleveland, OH, 1981) pp. $601-621$.

[84] P. Purtscher, Y. W. Cheng, and P. N. L1, Fatigue crack growth of duplex stalnless steel castings at $4 \mathrm{~K}$, in: Materials Studies for Magnetic Fusion Energy Applications at Low Temperatures - VII, National Bureau of Standards, Boulder, CO, NBS IR 84-3000 (May 1984) pp. 263-283. 
[85] T. A. Whipple and H. I. McHenry, Evaluation of weldments and castings for liquid helium service, in: Materials Studies for Magnetic Fusion Energy applications at Low Temperatures - IV, National Bureau of utandards, Boulder, CO, NBS IR 81-1645 (April 1981) pp. 273-287.

[06] Specification for corrosion-resisting chromium and chromium-nickel steel covered weldir.g electrodes, American Welding Society, AWS A $5.4-78$ (1978).

[87] Specification for corrosion-resisting chromium and chromium-nickel base and composite metal cored and stranded arc welding electrodes and welding rods, Arerican Welding Society, AWS A 5.9-77 (1977).

[88] E. N. C. Dalder, unfublished information, Lawrence Livermore National Laboratory, 1980.

[89] A. Backman and B. Lundquist, Welding Journal 56(1) (January 1977) pp. 240s-280s.

[90] Armco advanced materials - technical data manual, Armco steel Corporation, undated.

[91] J. M. Wells and M. W. Hagendorn, Evaluation of nitronic 33 stainless steel for TETR service applications, Westinghouse Research Laboratory, Report No. 75-8C3-WETWO-RL (September 26, 1975). 
[92] A. Randak, W. Wessling, H. E. Beck, H. Steimaurer, and L. Faust, Stahl und Eisen 91(22) (October 1971) 1255-1270.

[93] Avesta Handbook for the Welding of Stainless Steel, Avesta Jernverks $A B$ (1977).

[94] Avesta product information on Electrode Type 832 SKR-NF, Information No. 7428 .

[95] Avesta product information on Electrode Type P6, Information No. 7438 .

[96] Electrode news, Avesta P6, Avesta Jernverks AB, No. 7109E (May 21, 1977) p. 5 .

[97] R. P. Reed, R. L. Tobler, J. W. Elmer, H I. McHenry, and K. A. Yuschenko, Strength and toughness of USSR Fe $-20 \mathrm{Cr}-16 \mathrm{Ni}-6 \mathrm{Mn}$ - $0.2 \mathrm{~N}_{2}$ weldments at cryogenic temperatures, National Bureau of Standards, Boulder, Co, unpublished manuscript, May 1980.

[98] Bohler welding guide, Vereinigte Edelstahlwerke AG. (October 1978).

[99] Secheron flux coated electrodes, Secheron Welding, Ltd. (January 1979). 
[100] Taseto welding electrodes and welding rods, and wires, Nippon 0ils and Fats, Ltd. (October 1978).

[101] R. A. Swain, letter to E. N. C. Dalder, Data on Thyssen 19/15, February 27, 1979.

[102] K. F. Betrams, letter to E. N. C. Dalder, Information on Messrs. Griesheim welding products, January 10, 1979.

[103] K. Allanson, letter to E. N. C. Dalder, Technfcal Handibook - Welding Consumables, Metrode Products, Ltd., November 23, 1978.

[104] J. M. Cordea, D. A. Kammer, and D. C. Martin, Welding Journal 43(11) (1974) pp. 481s-491s.

[105] H. Fredriks and L. J. VanDerToorn, British Welding Journal (April 1968) $178-182$.

[106] T. G. Gooch and L. J. Honeycombe, Microcracking in fully austenitic stainless steel weld metal; overall assessment of the welding institute investigation, Report M/73/73 (June 1973).

[107] C. E. Witherell, Welding stainless steels for structures operating at liquid helium temperature, Lawrence Livermore National Laboratory, UCRL-83863, presented at the 69th Annual Meeting of the American Welding Soclety, April 1980. 
[108] C. J. Sullivan, EBASCO Services, Inc., November 1978, unpublished.

[109] D. T. Read, H. I. McHenry, P. A. Steinmeyer, and R. D. Thomas, Jr., Metallurgical factors affecting the toughness of $316 \mathrm{~L}$ SMA weldments at cryogenic temperatures, in: Materials Studies for Magnetic Fusion Applications at Low Temperatures - II, National Bureau of Standards, Boulder, CO, NBSIR 79-1609 (June 1979) p. 315.

[110] R. J. Castro and J. J. DeCadinet, Welding metallurgy of stainless and heat resisting steels (Cambridge University Press, 1974) pp. 95-106.

[111] F. Matsuda, H. Nakagawa, S. Katayama, and Y. Arata, Weld metal cracking of $25 \mathrm{Cr}-20 \mathrm{Ni}$ fully austenitic stainless steel; 61st Annual Meeting of the American Welding Society, April 1980.

[112] J. C. Lippold and H. F. Savage, Solidification of austenitic stainless steel weldments: A. Part I - A proposed mechanism, Welding Journal 58 (12), December 1979, pp. 362s-374s; B. Part II - The effect of alloy composition on ferrite morphology, Welding Journal 59(2) (February 1980) pp. 48s-58s.

[113] M. J. Cieslak and W. F. Savage, Weldabil.t ' and solidification phenomena of cast stainless steel, Welding Journal 59(5) (1980) pp. $136 \mathrm{~s}-146 \mathrm{~s}$. 
[114] N. Suutala, T. Takalo, and T. Mosio: a) Metallurgical transactions 10A, pp. 512-514; b) Metallurgical Transactions 10A, pp. 1173-1180; c) Metallurglcal Transactions 10A, pp. 1181-1190; d) Metallurgical Transactions 10A, pp. 717-725.

[115] T. Molsio, Solidification Microstructure and hot cracking in austenitic stainless steel weld metal, Thesis, University of Oulu, Finland (1974).

[116] V. Kujanpai, N. Suutala, T. Takalo, and T. Moisio, Welding Research International $9(2)(1979)$ pp. 55-76.

[117] V. Kujanpaa, N. Suutala, T. Taka1o, and T. Moisio, Metal Construction, 12(6) (June 1980).

[118] N. Suutala, Metallurgical Transactions A 14A (February 1983) pp. 191-197.

[119] V. Kujanpaa, Metâl Construction 17 (January 1985) pp. 40R-46R.

[120] J. Honeycombe and T. Gooch, Solidification oracking of high-speed TIG and laser welds in austenitic stainless steel sheet, Welding Inst1 tute, Report No. 224/1983 (August 1983).

[121] T. Ogawa and E. Tsunetomi, Helding Journal 71 (3) (1982) pp. 82s-93s. 
[122] J. A. Brooks, Composition effects on the microstructure and cracking of austenitic stainless steel welds, Dissertation, Department of Metallurgy and Materials Science, Carnegle Mellon University (April 1981 ).

[123] J. C. Lippold, Weld cracking mechanisms in austenitic stainless steels, in: Trends in Welding Research in the United States (ASM, Cleveland, OH November 1981).

[124] C. D. Lundin and C. P. D. Chou, "The cracking susceptibiliby of austenitic stainless steel weld metals, Welding Research Council, New York, Welding Research Council Bulletin 289 (November 1983).

[125] J. C. Borland, British Welding Journal 7(8) (July 1960).

[126] B. L. King, Weld metal and HAZ hot cracking in wrought austenitic stainless steels, British Welding Research Association Report C139/A/2/65 (February 1966).

[127] T. Senda, Welding Research Abroad, 18(6) (June 1972).

[128] I. Masumoto, K. Tamaki, and M. Katsuna, Journal of the Japanese Welding Society $41(11)(1972)$.

[129] Y. Arata et al., Trans, of the Japan Welding Research Institute $3(1)$ (1974). 
[130] L. K. Poole, Welding Journal 32(8) (1953) pp. 403s-412s.

[131] P. P. Puzak, W. R. Appblet, and W. S. Pelliri, Welding Journal 35(1) (1956) pp. 9s-17s.

[132] P. P. Puzak and H. Rischall, Welding Journal 36(2) (1957) pp. 57s-61s.

[133] F. P. Fairchild, ASME Transacioions 79(8) (1957).

[134] R. M. Curran and A. W. Rankin, ASME Transactions 79(8) (1957).

[135] R. M. Younger and R. G. Baker, Journal of the Iron and Steel Institute 196(10) (1960).

[136] R. S. Christoffel, Welding Journal 41(6) (1962) pp. 251s-256s.

[137] D. M. Shackelton, High temperature cracking mechanism in the heat-affected zone of $25 \mathrm{Cr}-20 \mathrm{Ni}$ stainless steel welds, British Welding Research Association Report M/47/69 (October 1969).

[138] E. C. Rollason and M. C. Bystram, Journal of the Iron and Steel Institute 169(12) (1951).

[139] J. N. Cordea, R. M. Evans, and D. C. Martin, Investigation to determine causes of fissuring in stainless steel and nickel alloy weld metals; Technical Documentary Report ASD-TDR-62-317 (June 1962). 
[140] D. M. Hadrlll and R. G. Baker, British Welding Journal 13(1) (January 1966).

[141] J. Honeycombe and T. G. Gooch, Metal Construction and Bricish Welding Journal 2(9) (1970).

[142] J. Honeycombe and T. G. Gooch, Metal Construction and British Welding Journal 4(1?) (1972).

[143] J. Honeycombe and T. G. Gooch, Metal Construction and British Welding Journal 7(3) (1975).

[144] H. C. Berghardt et al., An investigation of the properties of Type 316 stainless steel weldments containing austenitic microfissures, Southwest Research Institute, Project 17-3078, SWRI Topical Report No. 1 (August 15, 1971).

[145] R. D. Buchheidt et al., Laboratory studies of Type 316 stain?ess steel weld metal from Maine Yankee Reactor coolant system, Batelle Columbus Laboratories (September 17, 1971).

[146] H. Thielsch, Examination of Type 316 stainless steel weld deposit for microfissuring and delta ferrite contents for the Oconee Nuclear Power Station, Duke Power Company, Report No. 1507 (December 23, 1972). 
[147] C. D. Lundin, C. P. D. Chou, and C. J. Sullivan, Hot cracking resistance of austenitic stainless steel weld metals, 61 st Annual Meeting of the American Welding Society, April 1980.

[148] G. Rabensteiner, J. Tosch, and H. Schabereitel, Hot cracking problems in different fully austenitic weld metals, 61st Annual Meeting of the American Welding Society, April 1980.

[149] C. D. Lundin, Welding defects, their origin and effect, Second International Conference on Materlals Technology, Mexico City, August 1970 .

[150] Y. Arata, F. Matsuda and S. Katayama, a) Report I - Transactions of the Japan€se Welding Research Institute 5(2) (1976) 135-151; D) Report II -

- Transactions of the Japanese Welding Research Institute 6(1) (1977) 46-57; c) Report III - Transactions of the Japan Welding Soclety 6(2) iDecember 1977) 7-16.

[151] P. W. Jones, British Welding Journal 4 (1952) 189-197.

[152] F. C. Hull, Proc. of the American Soclety for Testing and Materials 60 (1960) 667-690.

[153] K. Saito, et al., Journal of the Japanese Welding Society Lo (1971) $1178-1180$. 
[154] .. D. Lundin and D. F. Spond, Welding Journal 55(11) (1976) pp. 356s$367 \mathrm{~s}$.

[155] C. D. Lundin, W. T. DeLong, and D. F. Spond, Welding Journal 55(6) (1976) pp. 145s-151s.

[156] H. I. MoHenry, National Bureau of Standards, Boulder, Co, personal communication, June 1980.

[157] J. M. Wells, W. A. Logsdon, and R. Kossowsky, Adv. Cryog. Eng. 24 (1978) 150-159.

[158] T. A. Whipple, Mechanical properties of stainless steel weldments at cryogenic temperatures, NBS-DOE Workshop on Materials at Low Temperatures, Vail, CO, October 1979.

[159] T. A. Whipple, H. I. McHenry, and D. T. Read, Fracture behavior of ferrite-free stainless steel welds in liquid helium, in: Materials Studies for Magnetic Fusion Energy Applications at Low Temperatures-III, NBSIR 80-1627 (June 1980) pp. 167-194.

[160] T. A. Whipple, National Bureau of Standards, Boulder, Co, personal communication, November 1979. 
[161] E. N. C. Dalder, Lawrence Livermore National Laboratory, unpublished information, June 1985.

[162] Harry Espey, Armco Steel Corporation, personal communication, April 1980.

[163] H. I. McHenry, D. T. Read, and P. A. Steinmayer, Evaluation of stainless steel weld metals at cryogenic temperatures, Materials Studies for Magnetic Fusion Energy Applications at Low Temperatures-II, NBSIR 79-1609 (June 1979) pp. 299-312.

[164] E. Szumachowski and H. F. Reid, Welding Journal 58(2) (1979).

[165] A. Marshall and J. C. M. Farrar, Metal Construction 16(6) (1984) 347353.

[166] A. Nyilas, KfK-Karlsruhe, personal communication, October 1982.

[167] W. G. Clarke, Jr., and S. J. Hudak, Jr., Variability in fatigue crack growth rate testing, ASTM E-24.04.-1 Task Group Report (September 18, 1974).

[168] R. L. Tobler and R. P. Reed, Adv. Cryog. Engrg. 24 (1978) 82-90. 
Table 1. Recommended design factors for superconducting magnet structures. ${ }^{a}$

Design stress $<2 / 3$ yield (primarily tension and combined) Design stress <90\% yield (primarily bending)

Design stress < $1 / 2$ ultimate tensile strength

Design stress $<1 / 2 K_{I C} \sqrt{\pi \alpha} b$

Design stress cycles $>4$ lifetimes

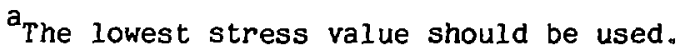

$b_{\text {The }} a$ is half-crack length. 
Table 2. Claracteristics of an "ideal" structural material.

\section{Spectal criteria}

1. Thermal contraction on cooling to $4 K>0.3 \%$.

2. "Low levels" of ferromagnetic behavior at $4 \mathrm{~K}$.

Strength related oriterla at $4 \mathrm{~K}$

1. High yield strength, $>690 \mathrm{MPa}$.

2. High elastic modulus, $>208 \mathrm{GPa}$.

3. High low- and high-cycle fatigue performance.

Ductility or toughness-related criteria, at $4 \mathrm{~K}$

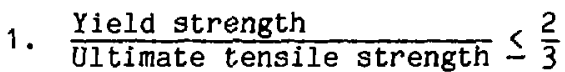
2. High plane-strain fracture toughness: high enough to avoid purely elastic action in thickest section used.
3. Low fatigue crack-growth rate.
4. High uniform and total elongations, reduction in area.

\section{Producibility-related criteria}

1. Low cost, preferrably $\leq \$ 4.50 / \mathrm{kilo}$.

2. Welds deposited by high deposition-rate processes with properties "as good as" those of base metal.

3. Weldable without need for post-weld heat treat.

4. Inspectable "in-place."

5. "Readily" formable and machinable. 


$$
-65-
$$

Ta. . List of acronyms.

\section{Weld process:}

ESW

FCMA

GMA

GTA

SA Or SAW

SMA

Cond1tion:

FC

LA

MA

$\mathrm{S}$

STQ

WQ
Electro-slag weld

Flux-covered metal arc

Gas-metal arc

Gas-tungsten arc

Submerged arc weld

shielded metal are

$1366 \mathrm{~K}(1 \mathrm{~h})$, slowly cooled in furnace

Lab annealed

Mill annealed

$922 \mathrm{~K}(1 \mathrm{~h})$, slowly cooled in furnace

$1450 \mathrm{~K}(1 \mathrm{~h})$, quenched in water

water quenched 
Table 4. Composition of wrought austenitic stainless steels for liquid helium service composition ( $\%$ ).

\begin{tabular}{|c|c|c|c|c|c|c|c|c|c|c|c|}
\hline Type & $c$ & $\mathrm{~N}$ & $\mathbf{P}$ & $S$ & Si & $\mathrm{Cr}$ & $\mathrm{Ni}$ & Mo & $M n$ & \multicolumn{2}{|c|}{ Other } \\
\hline AISI 304 & 0.08 & 0.10 & 0.045 & 0.03 & 1.0 & $18-20$ & $8-10 \cdot 5$ & $b$ & 2.0 & & \\
\hline $304 \mathrm{~L}$ & 0.03 & 0.10 & 0.045 & 0.03 & 1.0 & $18-20$ & $8-12$ & $\mathrm{~b}$ & 2.0 & & \\
\hline $304 \mathrm{LN}$ & 0.03 & $0.10 \cdots 0.16$ & 0.020 & 0.015 & 1.0 & $18-20$ & $9-12$ & $b$ & 2.0 & $P+S:$ & $0.03 \max$ \\
\hline $304 N$ & 0.08 & $0.10-0.16$ & 0.045 & 0.03 & 1.0 & $18-20$ & $8-12$ & $\mathrm{~b}$ & 2.0 & & \\
\hline 316 & 0.08 & 0.10 & 0.045 & 0.03 & 1.0 & $16-18$ & $19-14$ & $2-3$ & 2.0 & & \\
\hline $.316 \mathrm{LN}$ & 0.03 & $0.10-0.16$ & 0.045 & 0.03 & 1.0 & $16-18$ & $10-14$ & $2-3$ & 2.0 & & \\
\hline Nitronic 33 & 0.08 & $0.20-0.40$ & 0.060 & 0.03 & 1.0 & $17--19$ & $2.75-3.75$ & $\mathrm{~b}$ & $16.5-14.5$ & & \\
\hline 40 & 0.04 & $0.15-0.40$ & 0.060 & 0.03 & 1.0 & $19-21.5$ & $5.5-7.5$ & & $8-10$ & & , \\
\hline 50 & 0.06 & $0.10-0.40$ & 0.040 & 0.03 & 1.0 & $20.5-23.5$ & $11.5-13.5$ & $1.5-3.0$ & $4-6$ & $\mathrm{Cb}:$ & $0.1-0.3$ \\
\hline & & & & & & & & & & $v:$ & $0.1-0.3$ \\
\hline Kromarc 58 & $0.02-0.08$ & $0.24-0.30$ & $\mathrm{~b}$ & $\mathrm{~b}$ & $12-15$ & $14-17$ & $18-24$ & $1.75-2.75$ & $8-13$ & $\mathrm{~V}:$ & $0.12-0.24$ \\
\hline
\end{tabular}

${ }^{a}$ Composition in weight percent; maximum unless range is given.

Wot stated. 
Table 5. Chemical compositions of cast austenitic stainless steels for cryogenic service.

\begin{tabular}{|c|c|c|c|c|c|c|c|c|c|}
\hline \multirow[b]{2}{*}{ Grade } & \multirow{2}{*}{$\begin{array}{l}\text { Wrought } \\
\text { equivalent }\end{array}$} & \multicolumn{8}{|c|}{ Composition (g) } \\
\hline & & c & $\mathrm{Mn}$ & Si & $P$ & $s$ & $\mathrm{Cr}$ & $\mathbf{N}$ & Mo \\
\hline CF 3M & $316 \mathrm{~L}$ & $\begin{array}{l}0.03 \\
\max .\end{array}$ & $\begin{array}{l}1.5 \\
\max .\end{array}$ & $\begin{array}{l}1.5 \\
\max .\end{array}$ & $\begin{array}{l}0.04 \\
\max .\end{array}$ & $\begin{array}{l}0.04 \\
\max .\end{array}$ & $\frac{21}{17}$ & $\frac{13}{9}$ & $\frac{3}{2}$ \\
\hline CF8M & 316 & $\begin{array}{l}0.08 \\
\max .\end{array}$ & $\begin{array}{l}1.5 \\
\max .\end{array}$ & $\begin{array}{l}2.0 \\
\max .\end{array}$ & $\begin{array}{c}0.04 \\
\max .\end{array}$ & $\begin{array}{l}0.04 \\
\max \text {. }\end{array}$ & $\frac{21}{18}$ & $\frac{12}{9}$ & $\frac{3}{2}$ \\
\hline CF3 & $304 \mathrm{~L}$ & $\begin{array}{l}0.03 \\
\max .\end{array}$ & $\begin{array}{l}1.5 \\
\max .\end{array}$ & $\begin{array}{l}2.0 \\
\max .\end{array}$ & $\begin{array}{l}0.04 \\
\max .\end{array}$ & $\begin{array}{c}0.04 \\
\max .\end{array}$ & $\frac{21}{17}$ & $\frac{12}{8}$ & \\
\hline CF8 & 304 & $\begin{array}{l}0.08 \\
\max .\end{array}$ & $\begin{array}{l}1.5 \\
\max .\end{array}$ & $\begin{array}{l}2.0 \\
\max .\end{array}$ & $\begin{array}{l}0.04 \\
\max .\end{array}$ & $\begin{array}{l}0.04 \\
\max \text {. }\end{array}$ & $\frac{21}{18}$ & $\frac{11}{8}$ & \\
\hline Kromarc 55 & None & 0.04 & 9.5 & 0.30 & $a$ & a & 16 & 20 & 2.25 \\
\hline $\mathrm{CK}-20 \mathrm{Mod}$ & 310 & 0.03 & 4.1 & 1.35 & 0.003 & 0.037 & 23.7 & 22.6 & \\
\hline
\end{tabular}

${ }^{a}$ Not specified or reported. 
Table 6. Composition assumptions and calculations of nickel and chromium equivalents for Type $304 \mathrm{LN}$ steel for the MFTF-B magnet cases.

1. Composition assumptions: (\$)

C $\quad$ Mn $\mathrm{Cr} \quad \mathrm{Ni} \quad$ Si $\quad \mathrm{N}_{2}-$ Comment

$\begin{array}{lllllll}\frac{0.03}{0.01} & \frac{2.0}{0.5} & \frac{20.0}{18.0} & \frac{12.0}{8.0} & \frac{1.0}{0.25} & \frac{0.16}{0.10} & \frac{\text { High }}{\text { Low }}\end{array}$

2. Results for $\mathrm{E}_{\mathrm{Ni}}$ and $\mathrm{E}_{\mathrm{Cr}}$ calculations: ${ }^{\mathrm{a}}$

$\mathrm{E}_{\mathrm{Ni}} \quad \mathrm{E}_{\mathrm{Cr}} \quad \mathrm{E}_{\mathrm{Ni}} \quad \mathrm{E}_{\mathrm{Cr}}$

level level percent percent

Low Low $11.55 \quad 18.38$

$\begin{array}{lll}\text { Low High } \quad 11.55 & 21.50\end{array}$

$\begin{array}{lll}\text { High Low } & 18.70 & 18.38\end{array}$

$\begin{array}{llll}\text { High } & \text { High } & 18.70 & 21.50\end{array}$

3. Calculated upper and lower Iimits on $M_{S}$ and $M_{D}:^{b}$

\begin{tabular}{|c|c|c|c|}
\hline $\begin{array}{c}\text { Composition } \\
\text { limit } \\
\end{array}$ & $\begin{array}{c}\mathrm{M}_{\mathrm{S}} \\
\text { Eqn } 2 \\
\end{array}$ & $\begin{array}{c}\mathrm{M}_{\mathrm{S}} \\
\text { Egn } 4 \\
\end{array}$ & $\begin{array}{c}M_{D} \\
\text { Eqn } 5 \\
\end{array}$ \\
\hline Low & $21 \mathrm{~K}$ & $-128 \mathrm{~K}$ & $627 \mathrm{~K}$ \\
\hline High & -406 & -651 & 334 \\
\hline
\end{tabular}

$a_{E_{N i}}=q \mathrm{Ni}+30 \%\left(\mathrm{C}+\mathrm{N}_{2}\right)+0.5 \% \mathrm{Mn}, \mathrm{E}_{\mathrm{Cr}}=\% \mathrm{Cr}+\% \mathrm{Mo}+1.5 \% \mathrm{Si}+0.5 \mathrm{Cb}$.
$b_{\text {See Refs. } 11 \text { and } 32 .}$ 
Table 7. Summary of experimentally observed behavior of annealed Types 304LN and $304 \mathrm{~N}$ steels after straining at Iiquid helium temperatures.

\begin{tabular}{|c|c|c|c|c|c|c|}
\hline \multirow[b]{2}{*}{ Grade } & \multirow[b]{2}{*}{$\begin{array}{l}q \mathrm{Ni} \\
(q)\end{array}$} & \multirow[b]{2}{*}{$\begin{array}{l}q \mathrm{~N}_{2} \\
(q)\end{array}$} & \multirow{2}{*}{$\begin{array}{c}\text { Elongation } \\
\text { at } \\
\text { fracture } \\
\text { (\%) }\end{array}$} & \multicolumn{3}{|c|}{$\alpha^{\prime}$-martensite in: } \\
\hline & & & & $\begin{array}{c}\text { Erasture } \\
\text { area } \\
(\%)\end{array}$ & $\begin{array}{c}\text { Gage } \\
\text { length } \\
(x)\end{array}$ & $\begin{array}{l}\text { Grip } \\
(\$)\end{array}$ \\
\hline $304 \mathrm{~N}$ & 10.47 & 0.180 & $60.7 \%$ & 65 & -- & 0 \\
\hline $304 \mathrm{LN}$ & 10.10 & 0.134 & 42.0 & 90 & 80 & 0 \\
\hline $304 N$ & 11.25 & 0.120 & 43.0 & 90 & 54,61 & 0 \\
\hline \multirow[t]{2}{*}{$304 \mathrm{LN}$} & 10.15 & 0.165 & 72.2 & 90 & $45-70$ & 0 \\
\hline & 9.13 & 0.121 & 8.0 & & & \\
\hline
\end{tabular}

any ferromagnetic response was below the limits of detection of the experimental equipment or less than $0.5 \%$ ferromagnetic phase. 
Table 8. Cryogenic mechanical properties of cast austenitic stainless steels.

\begin{tabular}{|c|c|c|c|c|c|c|c|c|c|}
\hline Steel & $\begin{array}{l}\text { Wrought } \\
\text { analog }\end{array}$ & $\frac{\text { Tensil }}{\text { Temp. }}$ & $\frac{\text { e proper }}{\begin{array}{l}\text { U.T.S. } \\
\text { (MPa) }\end{array}}$ & $\frac{\text { rties }^{a}}{\text { Y.S. }}$ & $\begin{array}{c}\text { Elong. } \\
(g)\end{array}$ & $\begin{array}{l}\text { Reduction } \\
\text { in Area } \\
(\bar{\phi})\end{array}$ & 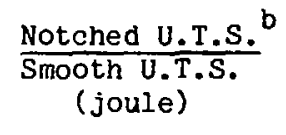 & $\begin{array}{l}\text { Charpy } V \text { notch } \\
\text { Energy absorbed }\end{array}$ & Conditions \\
\hline \multirow[t]{3}{*}{$\begin{array}{r}\text { Kromarc } \\
55\end{array}$} & None & 20 & 883 & 569 & 42.4 & 29.8 & 1.37 & 89 & $\begin{array}{l}\text { Heat-treated } \\
\text { at } 1366 \mathrm{~K} \\
\text { for } 1 \mathrm{hr} \text { and } \\
\text { air cooled. }\end{array}$ \\
\hline & & 4.2 & 725 & 580 & 52 & & & & \\
\hline & & 2.5 & 868 & 593 & 45 & & & & \\
\hline $\begin{array}{r}\text { Modified } \\
\mathrm{CK}-20\end{array}$ & $\begin{array}{l}310 \\
\text { plus } \\
5 \% \mathrm{Mn}\end{array}$ & 20 & 835 & 614 & 26.3 & & & 102 & \\
\hline
\end{tabular}

${ }_{b}^{a}$ U.T.S. - ultimate tensile strength; Y.S. = yield strength.

$\mathrm{b}_{\mathrm{T}}=10$ 
Table 9. Domestic stainless steel welding consumables.

\begin{tabular}{|c|c|c|c|c|c|c|c|c|c|c|}
\hline \multirow[b]{2}{*}{$\frac{\text { Covered electrodes }}{\mathrm{E} 308 \mathrm{t}}$} & \multicolumn{10}{|c|}{ Composition (wt $)$} \\
\hline & $\begin{array}{l}\frac{c}{.04} \\
\max .\end{array}$ & $\begin{array}{l}\frac{\mathrm{Si}}{.9} \\
\max .\end{array}$ & $\begin{array}{l}\frac{M n}{2.5} \\
\max .\end{array}$ & $\frac{P}{.04}$ & $\frac{S}{.03}$ & $\frac{\frac{C r}{21}}{18}$ & $\frac{\frac{N i}{11}}{9}$ & Mo & $\underline{\mathbf{V}}$ & $\begin{array}{l}\underline{N}_{26} \\
\text { typ. }\end{array}$ \\
\hline E308 & $\begin{array}{l}.08 \\
\max .\end{array}$ & $\stackrel{9}{\max .}$ & $\begin{array}{l}2.5 \\
\max .\end{array}$ & $\begin{array}{l}.04 \\
\max \end{array}$ & $\begin{array}{l}.03 \\
\max .\end{array}$ & $\frac{21}{18}$ & $\frac{11}{9}$ & & & $\begin{array}{l}.06 \\
\text { typ. }\end{array}$ \\
\hline E316L & $\begin{array}{l}.04 \\
\max \end{array}$ & $\stackrel{.9}{\max }$ & $\begin{array}{l}2.5 \\
\max \end{array}$ & .04 & $\begin{array}{l}.03 \\
\max \end{array}$ & $\begin{array}{l}20 \\
17\end{array}$ & $\begin{array}{l}14 \\
11\end{array}$ & $\begin{array}{l}2.5 \\
2.0\end{array}$ & & $\begin{array}{l}.06 \\
\text { typ. }\end{array}$ \\
\hline E316L plus Mn & .035 & .30 & 4.0 & .018 & .009 & 17.5 & 13.5 & 2.1 & & $\begin{array}{l}.06 \\
\text { typ. }\end{array}$ \\
\hline E316L (H1. ferrite) & .035 & .30 & 1.8 & .018 & .009 & 18.12 & 12.4 & $2 . i$ & & $\begin{array}{l}.06 \\
\text { typ. }\end{array}$ \\
\hline E316 & $\begin{array}{l}.08 \\
\max \end{array}$ & $\stackrel{9}{\max }$ & $\begin{array}{l}2.5 \\
\max \end{array}$ & $\begin{array}{l}.04 \\
\max \end{array}$ & $\begin{array}{l}.03 \\
\max .\end{array}$ & $\frac{20}{17}$ & $\frac{14}{11}$ & $\frac{2.5}{2.0}$ & & \\
\hline E310 & $\begin{array}{l}.20 \\
\max \end{array}$ & $\begin{array}{l}.75 \\
\max \end{array}$ & $\begin{array}{l}2.5 \\
\max \end{array}$ & $\begin{array}{l}.04 \\
\max \end{array}$ & $\begin{array}{l}.03 \\
\max \end{array}$ & $\frac{28}{25}$ & $\frac{22.5}{2}$ & & & $\begin{array}{l}.06 \\
\text { typ. }\end{array}$ \\
\hline $2 \mathrm{RM} 69$ & $\begin{array}{l}.02 \\
\max \end{array}$ & $\stackrel{\cdot 3}{\max }$ & $\frac{6}{3}$ & $\begin{array}{l}.015 \\
\max .\end{array}$ & $\begin{array}{l}.015 \\
\max .\end{array}$ & $\frac{26}{23}$ & $\frac{22}{20}$ & $\frac{3}{2}$ & & $\begin{array}{l}.20 \\
.10\end{array}$ \\
\hline N35W & $\frac{.07}{.049}$ & .4 & $\frac{12.0}{11.2}$ & $\begin{array}{l}.015 \\
\max .\end{array}$ & $\begin{array}{l}.015 \\
\max .\end{array}$ & $\frac{18.5}{17.9}$ & $\frac{4.92}{4.54}$ & & & $\frac{.24}{.16}$ \\
\hline N40W & .017 & .14 & 9.52 & .012 & .007 & 19.93 & 7.17 & & & .25 \\
\hline N50w & .06 & $\begin{array}{l}.5 \\
\max \end{array}$ & $\begin{array}{l}7 \\
5\end{array}$ & $\begin{array}{l}.025 \\
\max .\end{array}$ & $\begin{array}{l}.025 \\
\max .\end{array}$ & $\frac{24}{21}$ & $\frac{12}{10}$ & $\frac{2.6}{1.6}$ & $\frac{.25}{.15}$ & $\frac{.3}{.1}$ \\
\hline
\end{tabular}


Table 9. (continued).

\begin{tabular}{|c|c|c|c|c|c|c|c|c|c|c|c|}
\hline \multirow[b]{2}{*}{ Bare wire and rod } & \multicolumn{11}{|c|}{ Composition (wt\%) } \\
\hline & $\mathrm{C}$ & $\underline{\text { Si }}$ & $\underline{M n}$ & P & $\underline{S}$ & $\underline{\mathrm{Cr}}$ & $\underline{\mathrm{Ni}}$ & Mo & $\underline{\mathrm{V}}$ & $\underline{N}_{2}$ & $\mathrm{Cb}$ \\
\hline ER308L & $\begin{array}{l}.03 \\
\max \end{array}$ & $\frac{.60}{.25}$ & $\frac{2.5}{1.0}$ & $\frac{.03}{\max .}$ & $\frac{.03}{\max }$ & $\frac{2.2}{19.5}$ & $\frac{11}{9}$ & & & $\begin{array}{l}.08 \\
\text { typ. }\end{array}$ & \\
\hline E308 & $\begin{array}{l}.08 \\
\max \end{array}$ & $\frac{.60}{.25}$ & $\frac{2.5}{1.0}$ & $\frac{.03}{\max .}$ & $\frac{.03}{\max }$ & $\frac{22}{19.5}$ & $\frac{11}{9}$ & & & $\begin{array}{l}.08 \\
\text { typ. }\end{array}$ & \\
\hline ER316L & $\begin{array}{l}.03 \\
\max .\end{array}$ & $\frac{.60}{.25}$ & $\frac{2.5}{1.0}$ & $\begin{array}{l}.03 \\
\max .\end{array}$ & $\begin{array}{l}.03 \\
\max .\end{array}$ & $\frac{20}{18}$ & $\frac{14}{11}$ & $\begin{array}{l}3 \\
2\end{array}$ & & $\begin{array}{l}.08 \\
\text { typ. }\end{array}$ & \\
\hline ER316 & $\begin{array}{l}.08 \\
\max .\end{array}$ & $\frac{.60}{.25}$ & $\frac{2.5}{1.0}$ & $\begin{array}{l}.03 \\
\max .\end{array}$ & $\begin{array}{l}.03 \\
\max .\end{array}$ & $\frac{20}{18}$ & $\frac{14}{11}$ & $\frac{3}{2}$ & & $\begin{array}{l}.08 \\
\text { typ. }\end{array}$ & \\
\hline ER310 & $\frac{.15}{.08}$ & $\frac{.60}{.25}$ & $\frac{2.5}{1.0}$ & $\begin{array}{l}.03 \\
\max .\end{array}$ & $\begin{array}{l}.03 \\
\max \end{array}$ & $\frac{28}{25}$ & $\frac{22.5}{20}$ & & & $\begin{array}{l}.08 \\
\text { typ. }\end{array}$ & \\
\hline 2RM69 & $\begin{array}{l}.02 \\
\max .\end{array}$ & $\begin{array}{l}3 \\
\max \end{array}$ & $\frac{6}{3}$ & $\begin{array}{l}.015 \\
\max .\end{array}$ & $\begin{array}{l}.015 \\
\max .\end{array}$ & $\frac{26}{23}$ & $\frac{22}{20}$ & $\frac{3}{2}$ & & $\frac{.20}{.10}$ & \\
\hline N35W & $\frac{.053}{.04}$ & $\frac{.6}{.4}$ & $\frac{12.37}{11.40}$ & $\begin{array}{l}.025 \\
\max .\end{array}$ & $\begin{array}{l}.025 \\
\max .\end{array}$ & $\frac{18.4}{17.8}$ & $\frac{4.96}{3.94}$ & & & $\frac{.38}{.18}$ & \\
\hline $13-20 \mathrm{cb}$ & $\frac{.051}{.045}$ & .4 & $\frac{162}{9.7}$ & $\begin{array}{l}.015 \\
\max .\end{array}$ & $\begin{array}{l}.015 \\
\max .\end{array}$ & $\frac{15.7}{13.9}$ & $\frac{20.9}{12.3}$ & & & $\frac{.21}{.056}$ & $\frac{1.80}{1.02}$ \\
\hline N4OW & .022 & .39 & 9.29 & .011 & .006 & 19.68 & 7.09 & & & .223 & \\
\hline N50W & $\begin{array}{c}.06 \\
\max .\end{array}$ & $\stackrel{5}{\max }$ & $\begin{array}{l}7 \\
5\end{array}$ & $\begin{array}{l}.025 \\
\max .\end{array}$ & $\begin{array}{l}.025 \\
\max .\end{array}$ & $\frac{24}{21}$ & $\frac{12}{10}$ & $\frac{2.6}{1.6}$ & $\frac{.25}{.15}$ & $\frac{.3}{.1}$ & \\
\hline
\end{tabular}



Table 11. Comparison of austenitic stainless steels on the basis of 4-K yieldstrength, fracture toughness, and fatigue-crack growth.

\begin{tabular}{|c|c|c|c|c|c|c|}
\hline Alloy & No ferrite & Ferrite & $\begin{array}{l}\text { Product } \\
\text { form }\end{array}$ & $\begin{array}{l}\text { Yleld } \\
\text { strength } \\
\text { (MPa) }\end{array}$ & $\begin{array}{l}\text { Fracture } \\
\text { toughness } \\
\left(\mathrm{MPa} \cdot \mathrm{m}^{1 / 2}\right)\end{array}$ & $\begin{array}{c}\text { Fatigue crack } \\
\text { growth at } \\
50 \mathrm{MPa} \cdot \mathrm{m}^{1 / 2} \Delta \mathrm{K} \\
\text { (mm per cycle) }\end{array}$ \\
\hline $310 s$ & $x$ & & Plate & 790 & 240 & $3 \times 10^{-4}$ \\
\hline 310 & $x$ & & Weld & 810 & 120 & -- \\
\hline \multirow[t]{2}{*}{$20-16-6$} & $x$ & & Plate & 1150 & 145 & -- \\
\hline & & & Keld & $1000-1200$ & $200-150$ & --- \\
\hline CF8 & $x$ & & Casting & 413 & 131 & -- \\
\hline $304 \mathrm{LN}$ & $x$ & & Plate & $620-880$ & $290-210$ & $1.8 \times 10^{-3}$ \\
\hline $316 \mathrm{LN}$ & $x$ & & Plate & $900-1150$ & $260-200$ & $1.0-3.0 \times 10^{-4}$ \\
\hline $316 L$ & & $x$ & Weld & $880-900$ & $190-75$ & $3.0-6.0 \times 10-4$ \\
\hline $\mathrm{CF} 8 \mathrm{M}$ & & $x$ & Casting & $560-860$ & $149-84$ & $\begin{array}{l}3.5 \times 10^{-4} \text { to } \\
2.0 \times 10^{-3}\end{array}$ \\
\hline
\end{tabular}




\section{FIGURE CAPTIONS}

Figure 1. Tokamak fusion test reactor.

Figure 2. The MFTF-B axicell.

Figure 3. One pair of MFTF-B yin-yang magnets.

Figure 4. Fracture toughness vs ferrite content for E316L weldments.

Figure 5. Use of DeLong diagram to determine range of composition for the austenitic stainless steel.

Figure 6. Deperidence of 4-K yield strength of austenitic stainless steels on carbon and nitrogen contents.

Figure 7. Plane-strain fracture toughness vs yield strength at $4 \mathrm{~K}$ for austenitic stainless steels.

Figure 8. Axlal-load controlled fatigue performance of stainless steel bar at $4 \mathrm{~K}$.

Figure 9. Strain-controlled fatigue performance of austenitic stainless steels at $4 \mathrm{~K}$.

Figure 10. Fatigue-crack growth behavior of microstructurally stable austenitic stainless steels at $4 \mathrm{~K}$.

Figure 11. Fatigue-srack growth behavior of various austenitic stainless steels at $4 \mathrm{~K}$.

Figure 12. Fatigue-crack growth behavior of Types 304 and 316 steels at $4 \mathrm{~K}$.

Figure 13. Fatigue-crack growth data at $4 \mathrm{~K}$ for three wrought austenitic stainless steels before and after a "sensitization" heat treatment.

Figure 14. Fatigue-crack growth rates of stable and unstable austenitic stainless steels.

Figure 15. Microstructure of sensitized Type 304LN plate after fatigue crackgrowth testing at $4 \mathrm{~K}$. Note (a) carbonitride-laden grain boundaries and (b) intergranular fracture.

Figure 16. Schoefler diagram.

Figure 17. Yield strength at $4 \mathrm{~K}$ vs sum of carbon and nitrogen contents for ferrite-containing austenitic stainless steel castings.

Figure 18. The strength-toughness trend for austenitic stainless steel castings compared to that for wrought alloys.

Figure 19. Plane-strain fracture toughness and yleld strength of austenitic stainless steel coatings at $4 \mathrm{~K}$ as functions of ferrite content. 
Figure 20. Plane-strain fracture toughness and yield strength at $4 \mathrm{~K}$ as functions of nitrogen content for CFBM austenitic stainless steel castings with $9 \pm 1 \%$ ferrite.

Figure 21. Fatigue crack-growth behavior of CF8M castings at $4 \mathrm{~K}$.

Figure 22. Locations of some stainless steel welding consumables on DeLong diagram.

Figure 23. Analytical relationship between magnetic permeability and volume percent ferrite in austenitic stainless steel weldments.

Figure 24. Schematic pseudo-binary diagram of the $\mathrm{Fe}-\mathrm{Cr}-\mathrm{Ni}$ ternary system, illustrating the effect of composition on austenite-ferrite morphology in austentic stainless steel weldments.

Figure 25. Proposed solidification model for austenitic and austeniticferrite weld metals (schematic): (a) Type A--the weld metal solidifies completely to austenite and no further high-temperature transformation takes place. (b) Type A--austenite is the leading phase and delta-ferrite solidifies from the rest of the melt.

(c) Type B--delta-ferrite is the leading phase, austenite solidifies from the rest of the melt, and a quick transformation of $\delta$ to $\gamma$ takes place at high temperatures. (d) As in (c), but a higher volume fraction of ferrite at room temperature is present. (e) Type c--the weld metal solidifies completely to delta-ferrite and austenite forms through a solid-state transformation.

Figure 26. Summary of fissure-bend test on austenitic stainless steel weld metals.

Figure 27. Plane-strain fracture toughness vs yield strength for austenitic stainless steel welds at $4 \mathrm{~K}$.

Figure 28. Plane-strain fracture toughness vs yield strength at $4 \mathrm{~K}$ for various austenitic stainless steel weld metals.

Figure 29. Longitudinal fracture toughness as a function of ferrite-number for shielded metal are (SMA) welds.

Figure 30. Fatigue-crack growth performance of Type $316 \mathrm{~L}$ weld metals at $4 \mathrm{~K}$.

Figure 31. Fatigue-crack-growth behavior of various stainless steel weld metals at $4 \mathrm{~K}$.

Figure 32. Comparison of fatigue-crack growth behavior at $4 \mathrm{~K}$ of microstructurally stable and unstable austenitic stainless steel weld metals. 
Dalder, Juhas - Figure 1

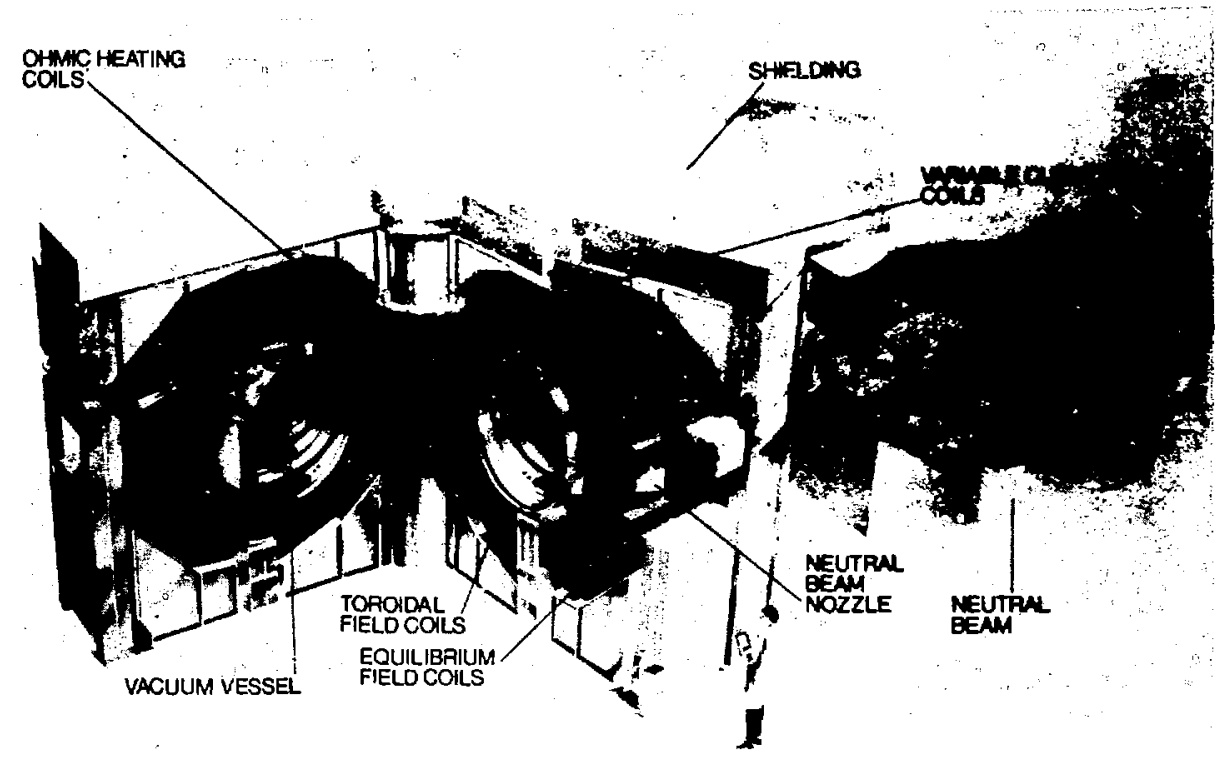


Dalder, Juhas - Figure 2

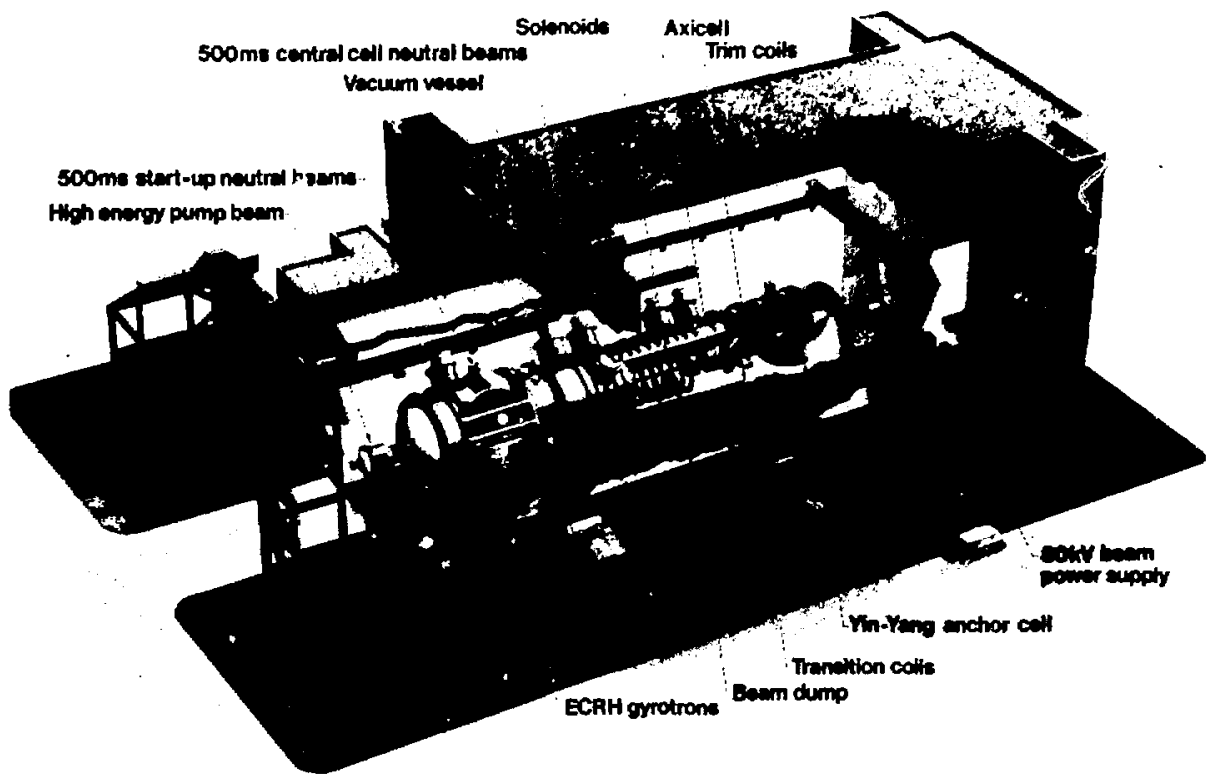


Dalder, Juhas - Figure 3

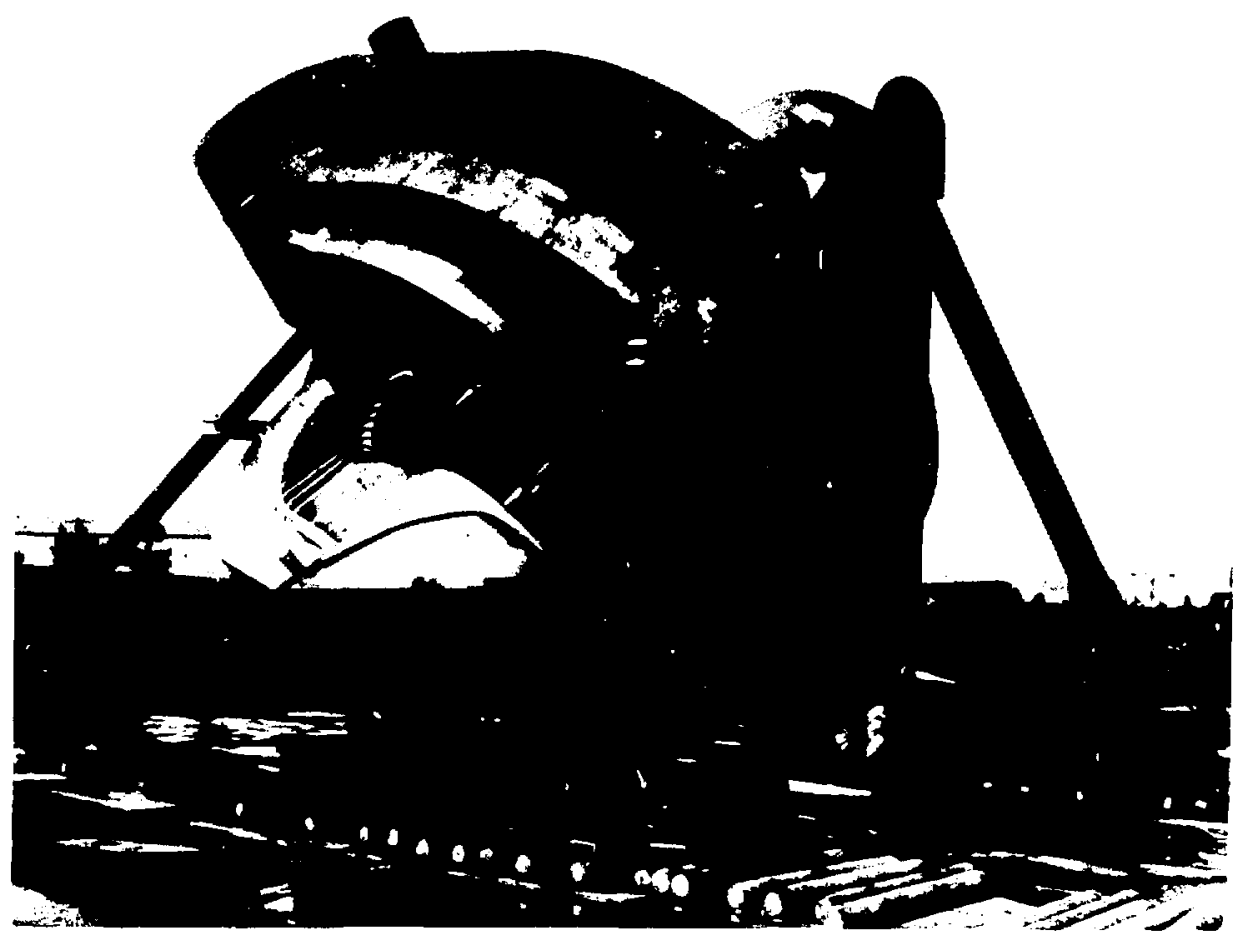


Dalder, Juhas - Figure 4

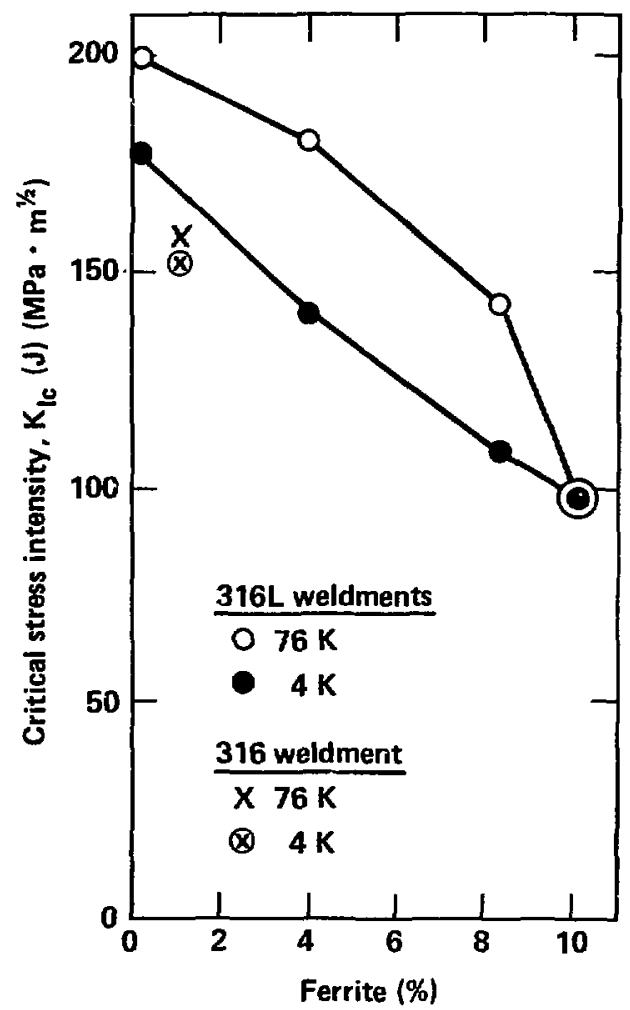


Dalder, Juhas - Figure 5

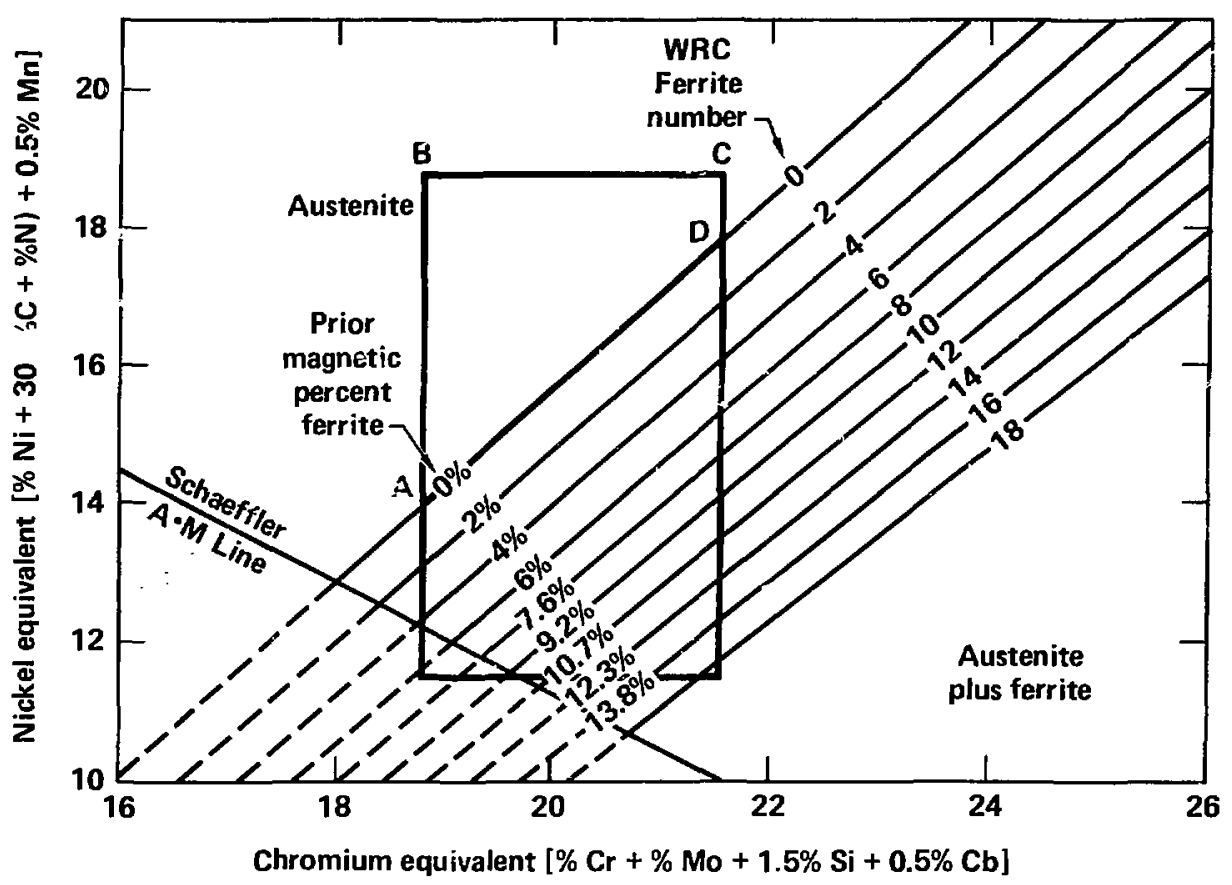

For line $A D$ :

(1) $\begin{aligned} & \frac{\mathrm{E}_{\mathrm{Ni}}-\mathrm{E}_{\mathrm{Ni}_{\mathrm{A}}}}{\mathrm{E}_{\mathrm{Ni}_{\mathrm{D}}}-\mathrm{E}_{\mathrm{Ni}_{\mathrm{A}}}}=\frac{\mathrm{E}_{\mathrm{Cr}}-\mathrm{E}_{\mathrm{Cr}_{\mathrm{A}}} ;}{\mathrm{E}_{\mathrm{Cr}_{\mathrm{D}}}-\mathrm{E}_{\mathrm{Cr}_{\mathrm{A}}}} \mathrm{E}_{\mathrm{Ni}_{\mathrm{A}}} \sim 13.4 \% \\ & \therefore \mathrm{E}_{\mathrm{Ni}_{\mathrm{D}}} \sim 17.7 \% \\ & \mathrm{E}_{\mathrm{Cr}_{\mathrm{A}}} \approx 1.613 \mathrm{E}_{\mathrm{Cr}}-16.277 \mathrm{E}_{\mathrm{Cr}_{\mathrm{D}}} \sim 21.5 \%\end{aligned}$

(2) $\% \mathrm{Ni}+30 \% \mathrm{C}+30 \% \mathrm{~N}+0.5 \% \mathrm{Mn}$

$\cong 1.673 \% \mathrm{Cr}+1.613 \% \mathrm{Mo}+2.420 \% \mathrm{Si}+0.20 \% \mathrm{Cb}-16.277$ 
Dalcer, Juhas - Figure 6

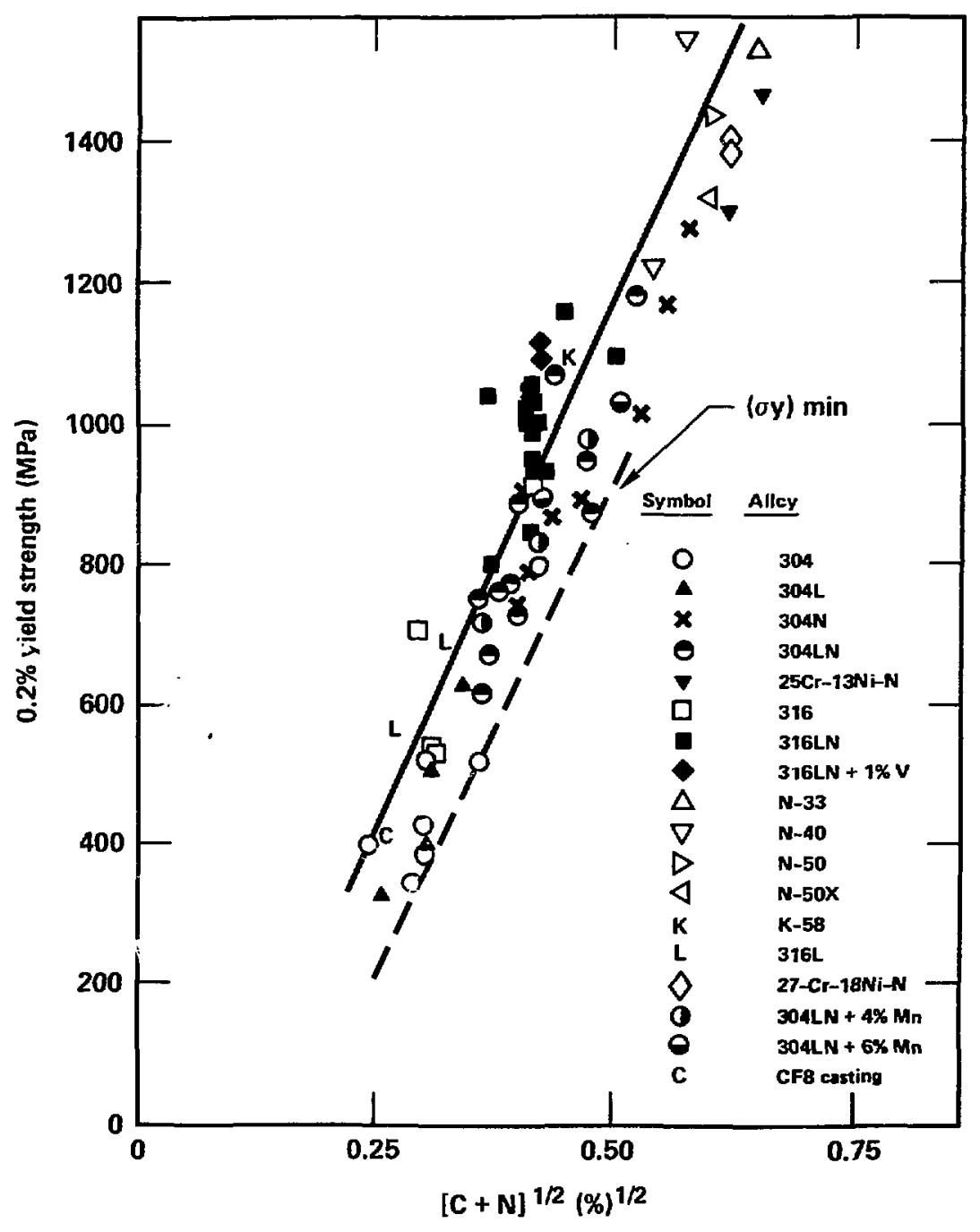


Dalder, Juhas - Figure 7

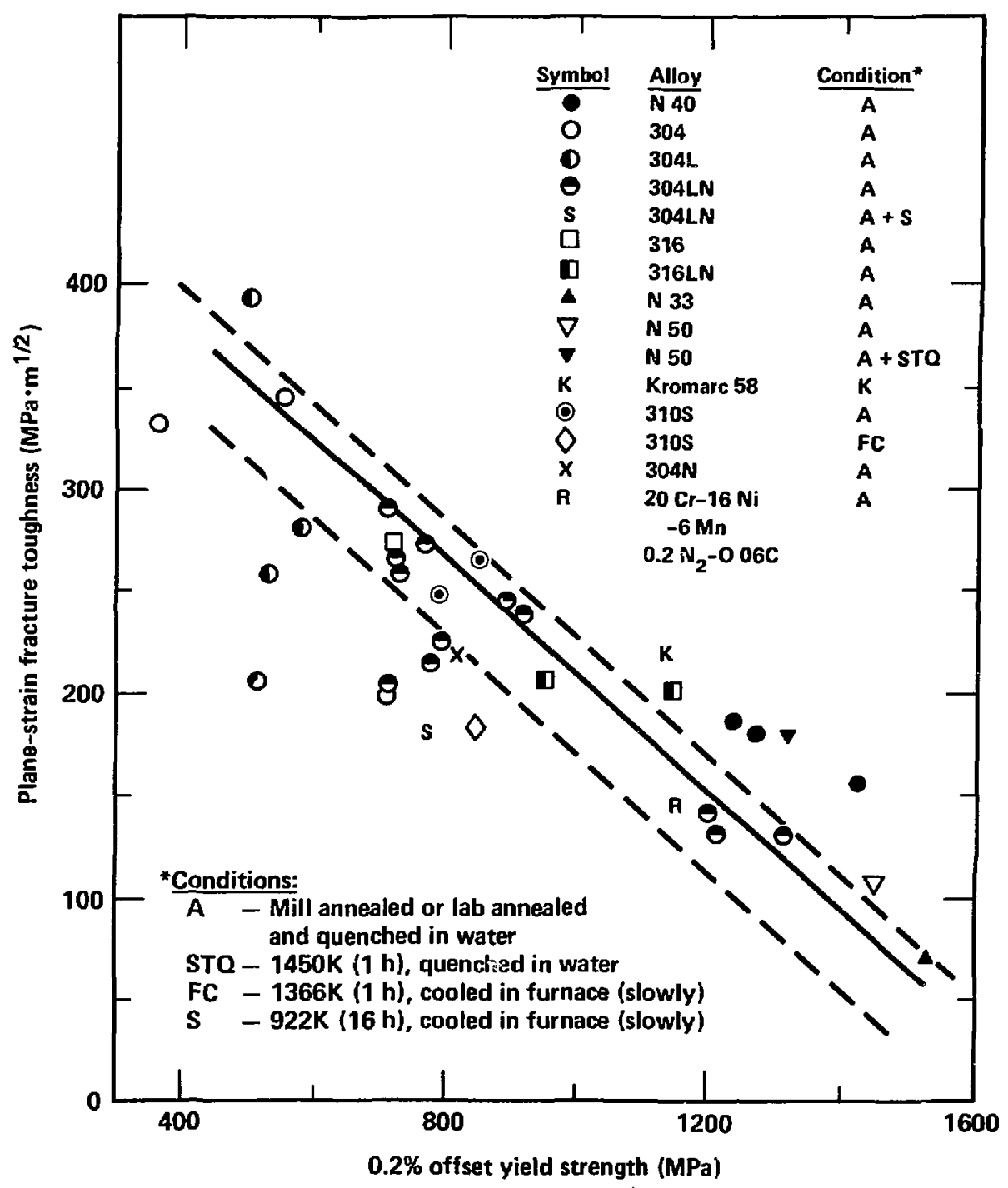




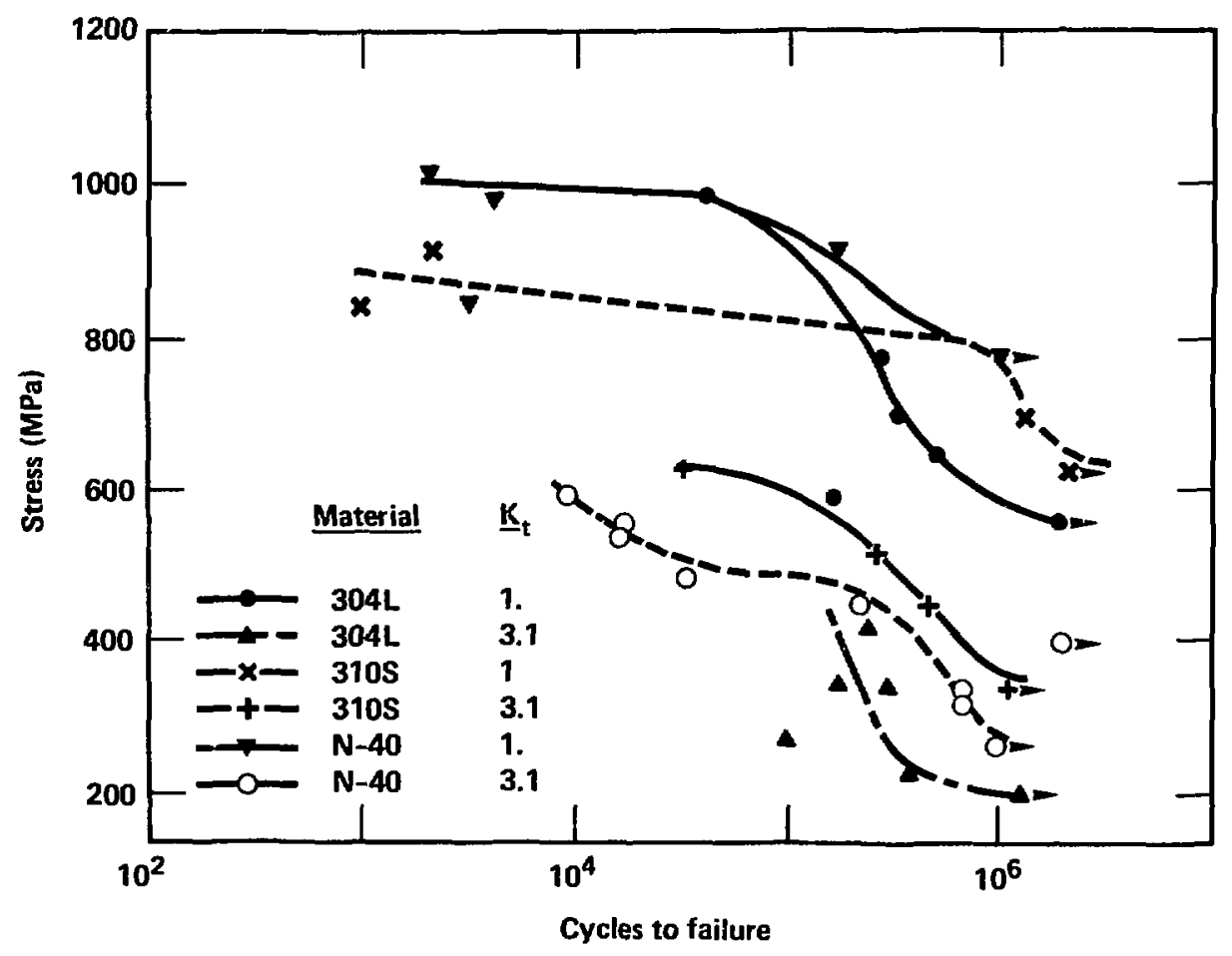


Dalder, Juhas - Figure 9

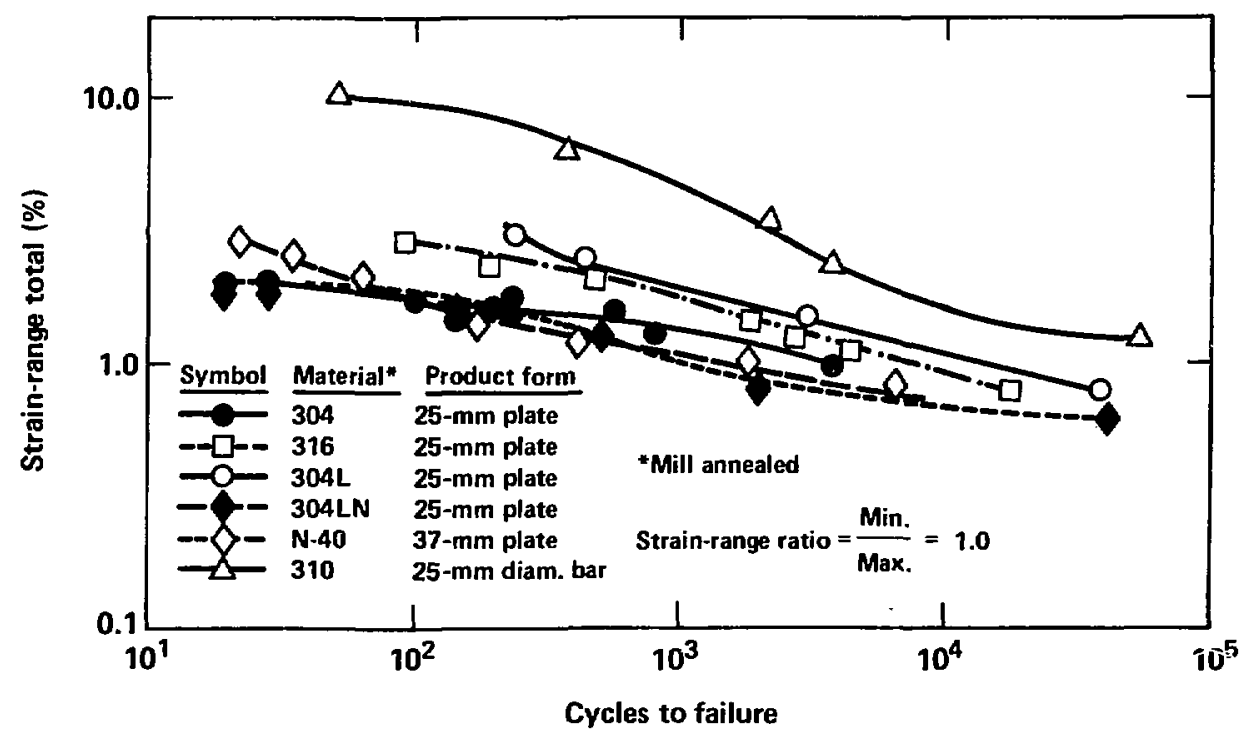




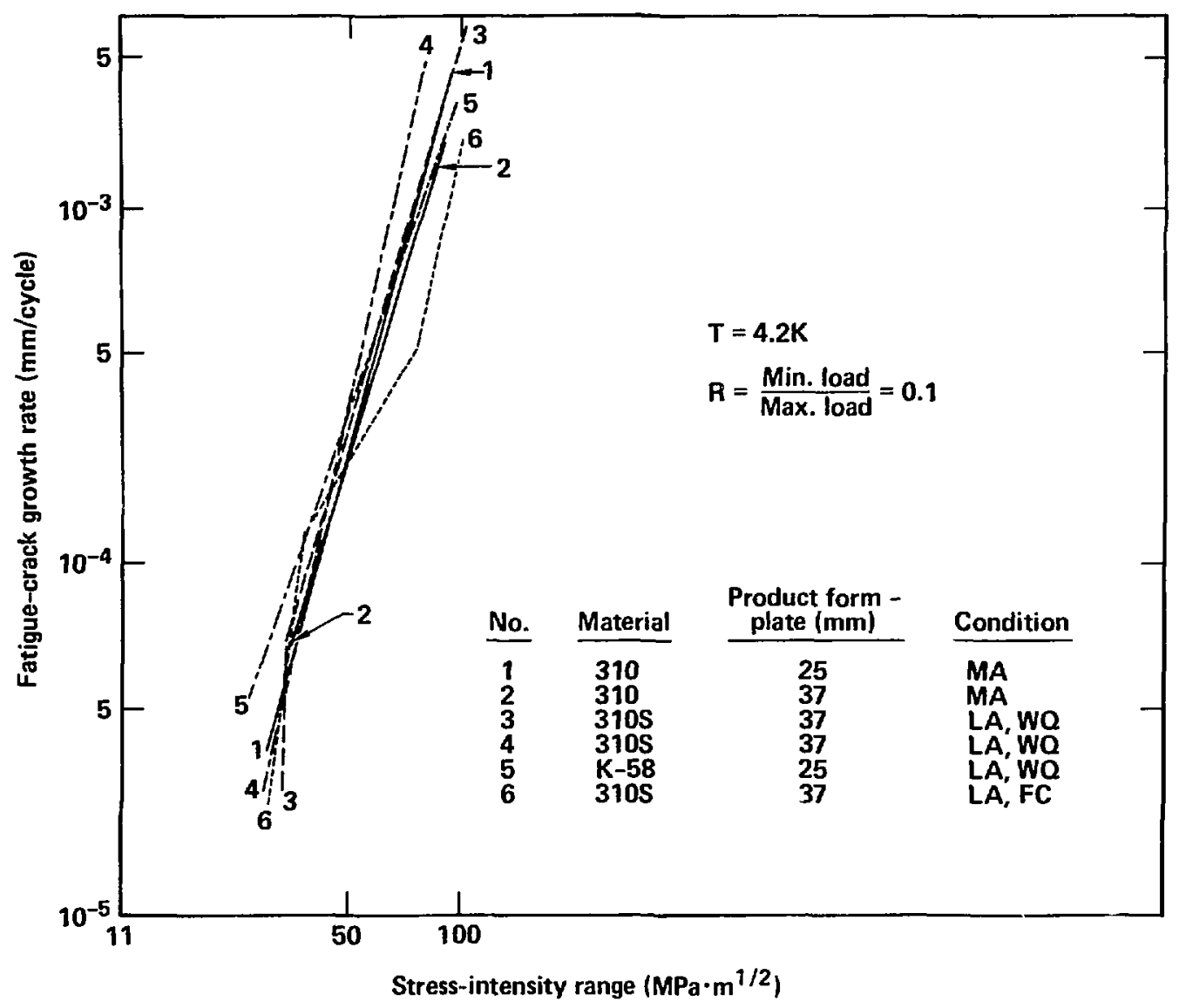


Dalder, Juhas - Figure 11

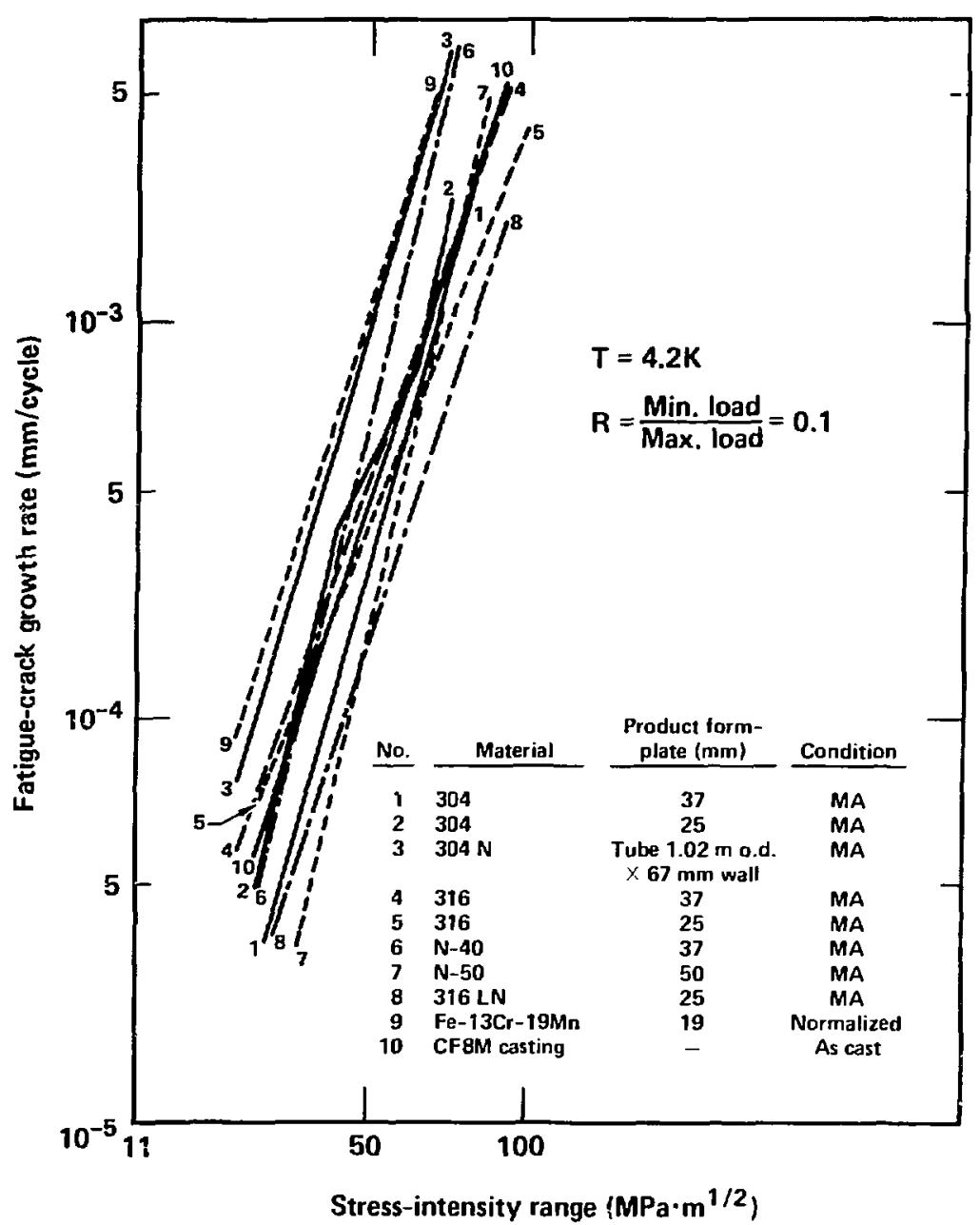


Dalder, Juhas - Figure 12

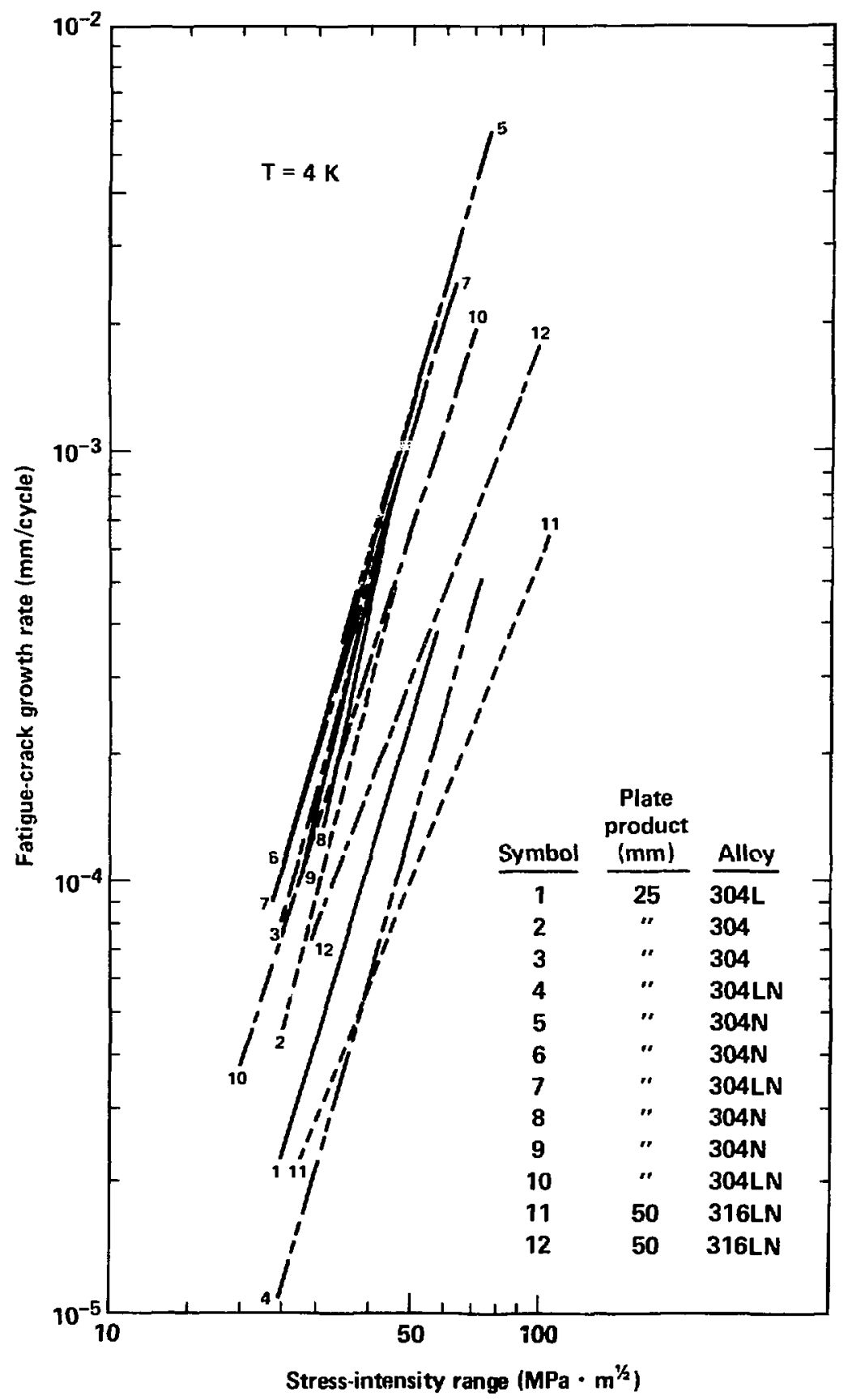




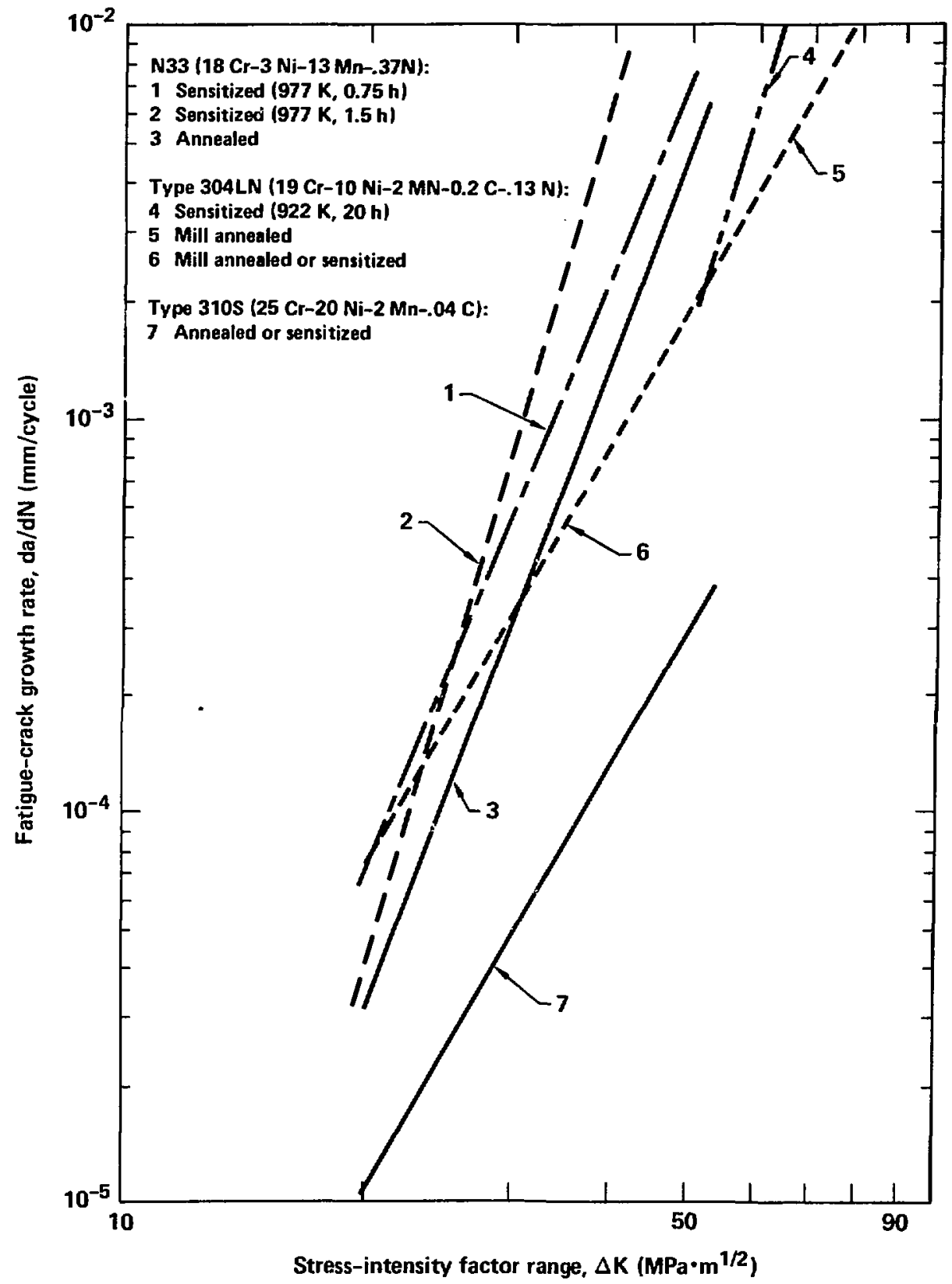




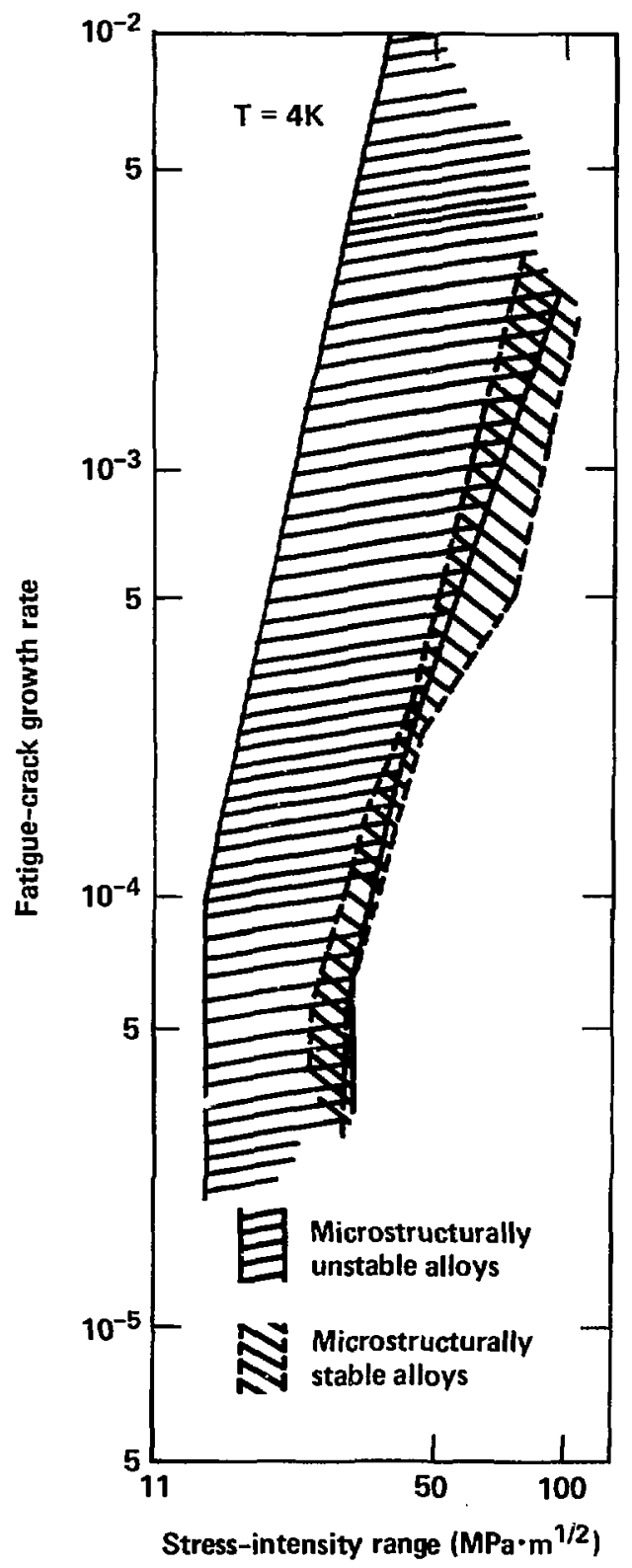


Dalaer, Juhas - Figure 15
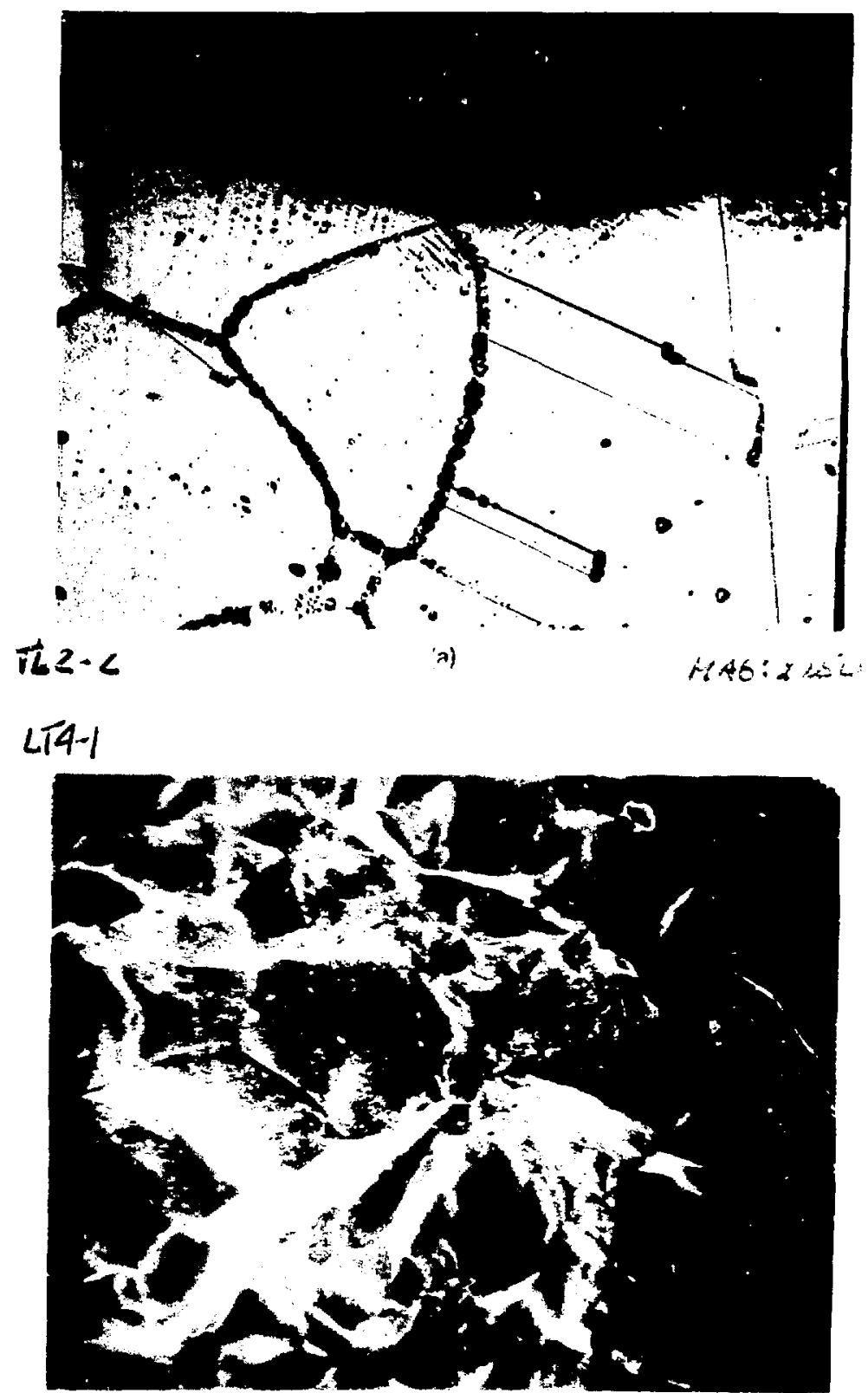

(b)

$M A 6: X 70$ 


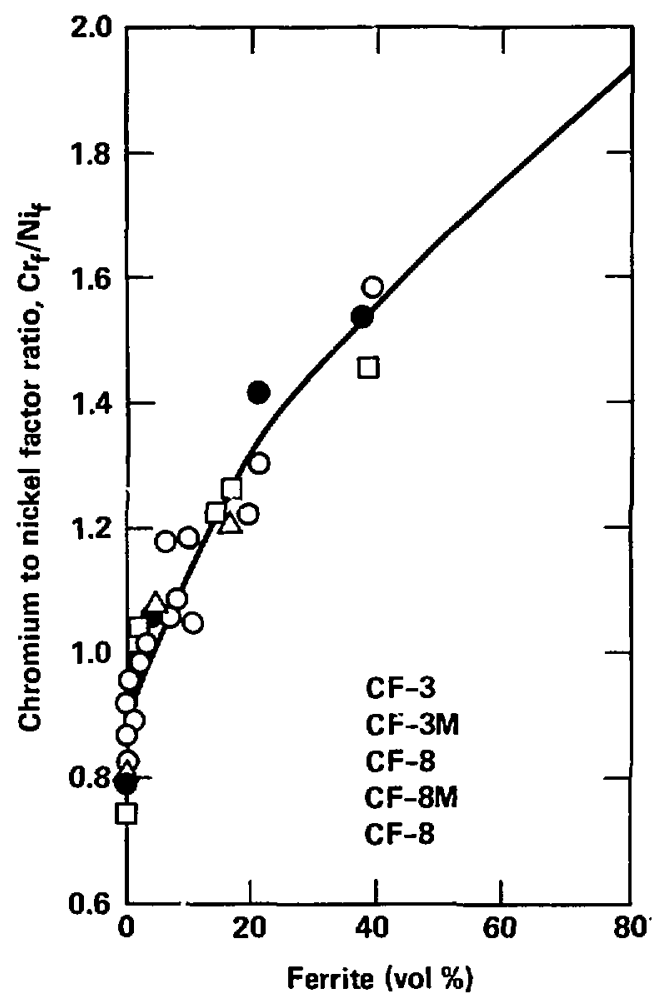


Dalder, Juhas - Figure 17

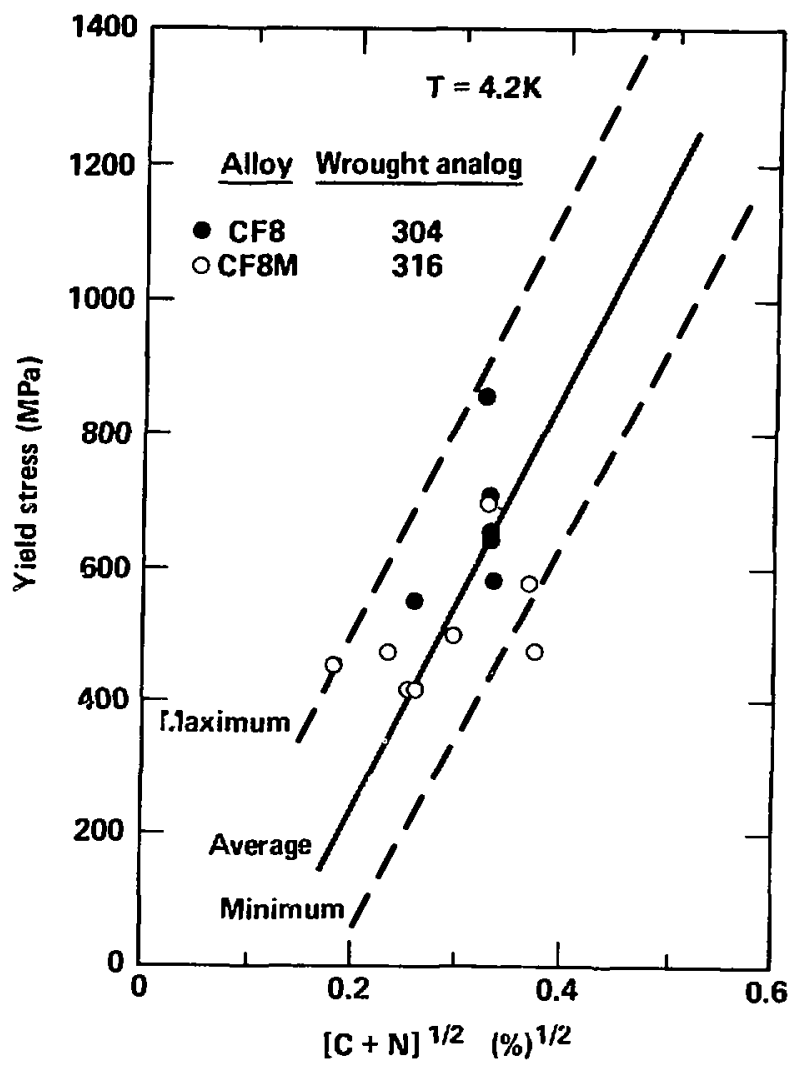


Dalder, Juhas - Figure 18

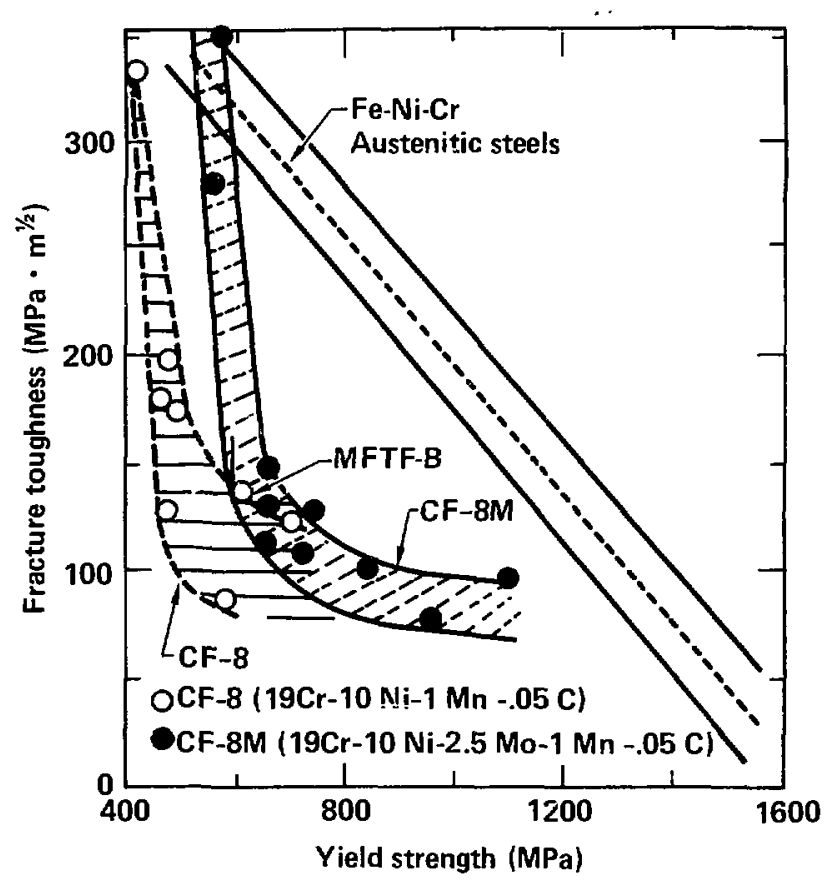


Dalder, Juhas - Figure 19

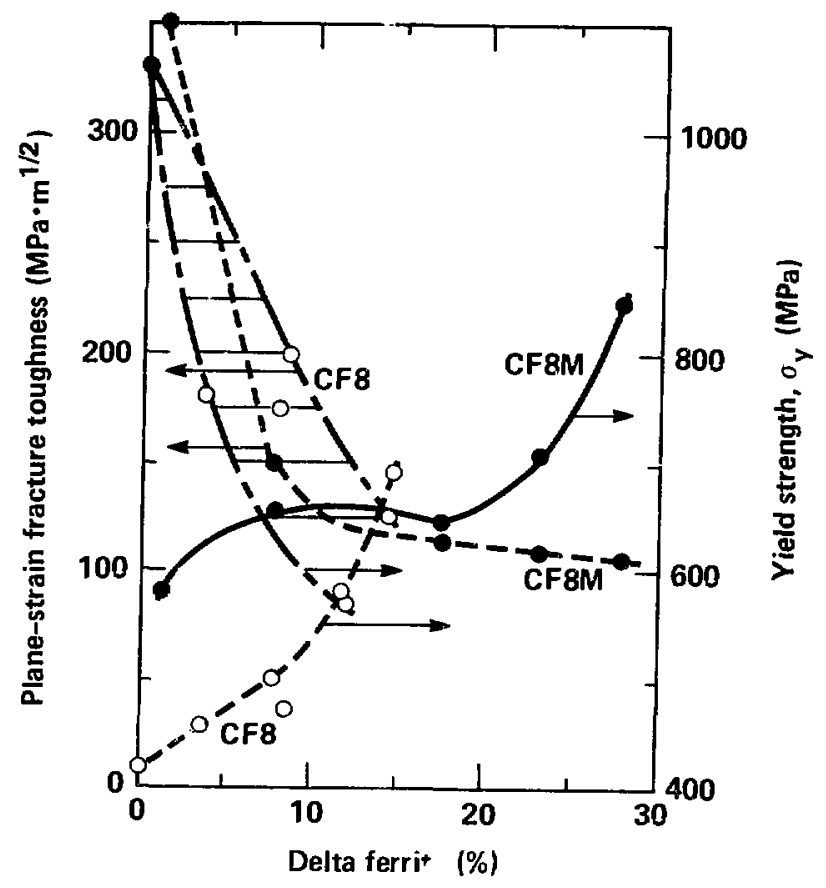


Dalder, Juhas - Figure 20

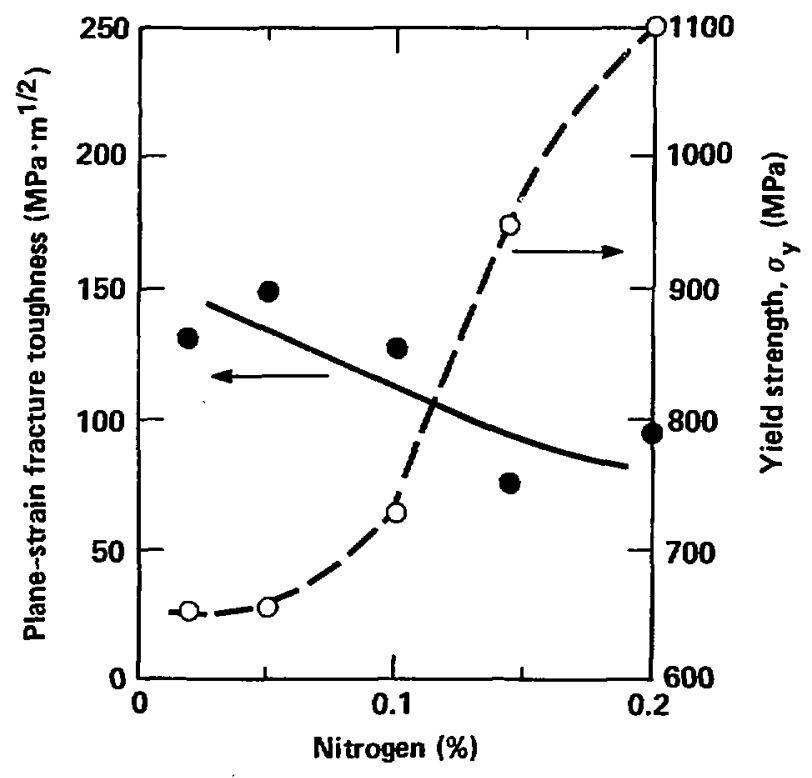


Fatigue-crack growth rate ( $\mathrm{mm} / \mathrm{cycle}$ )

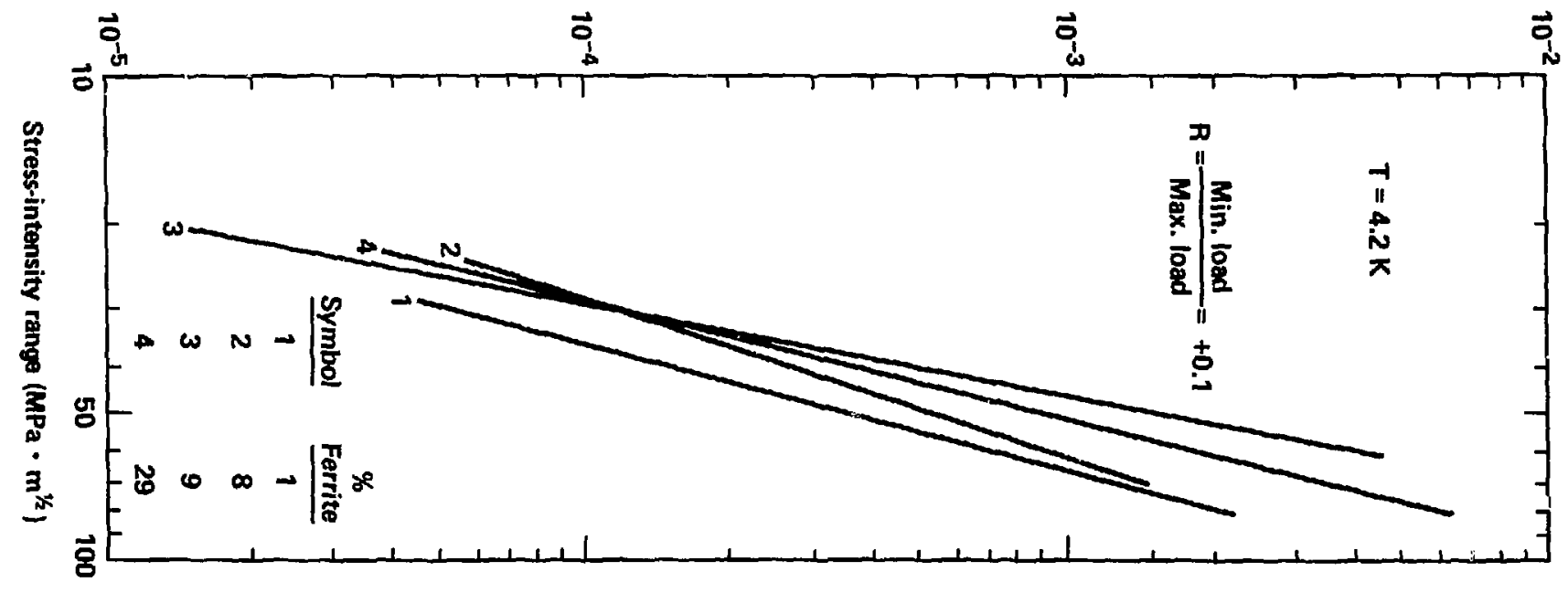




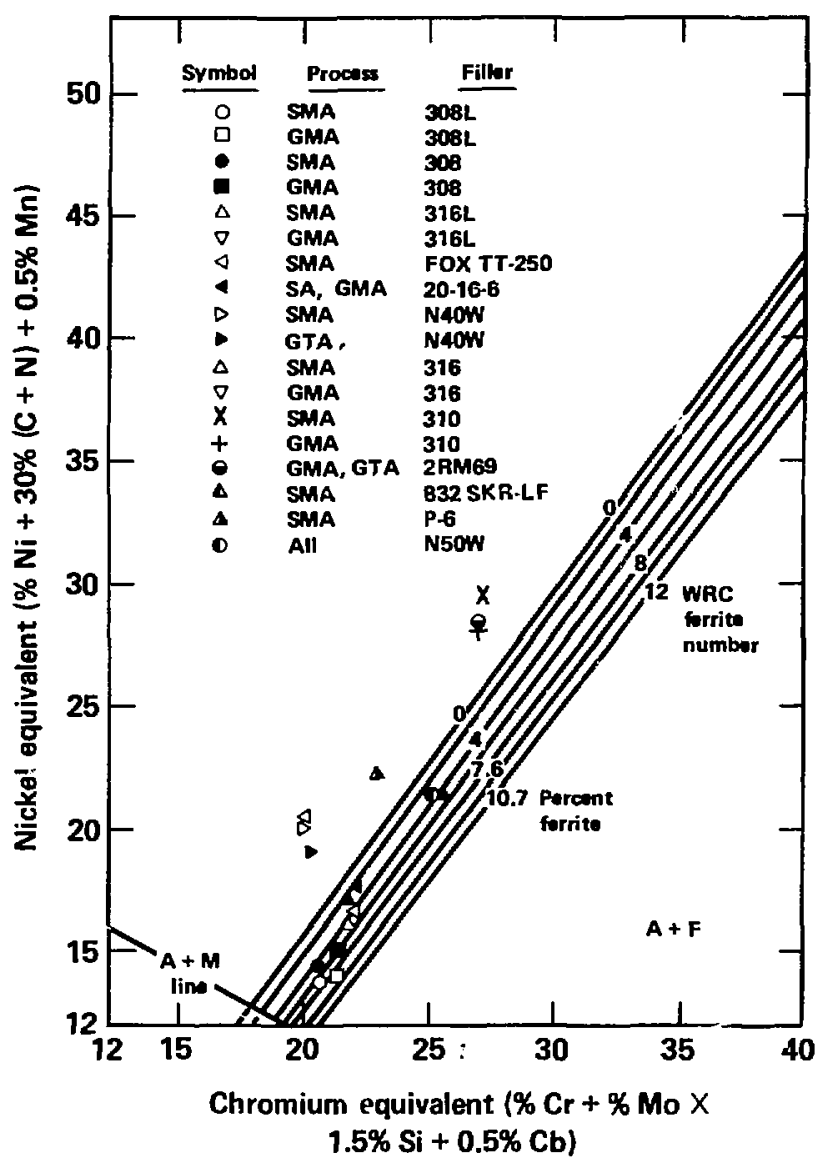




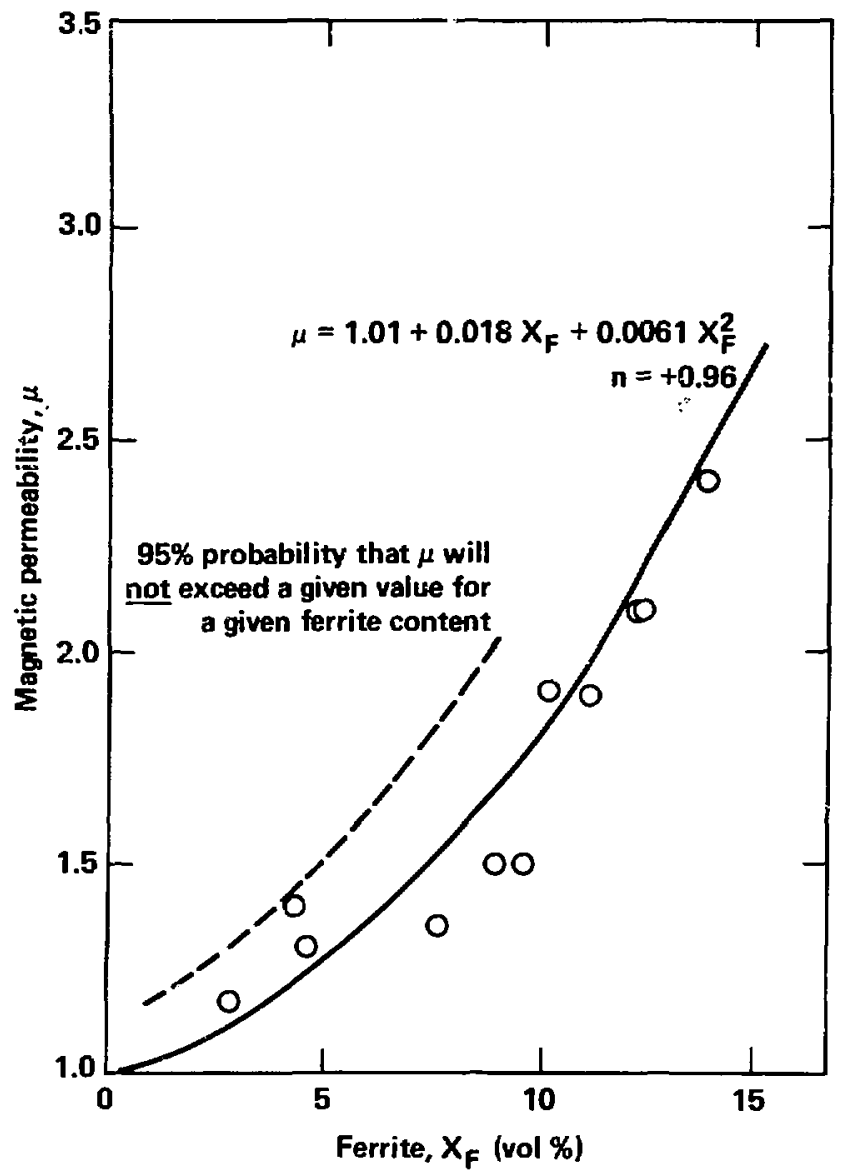


Daider, Julias - Figure 24

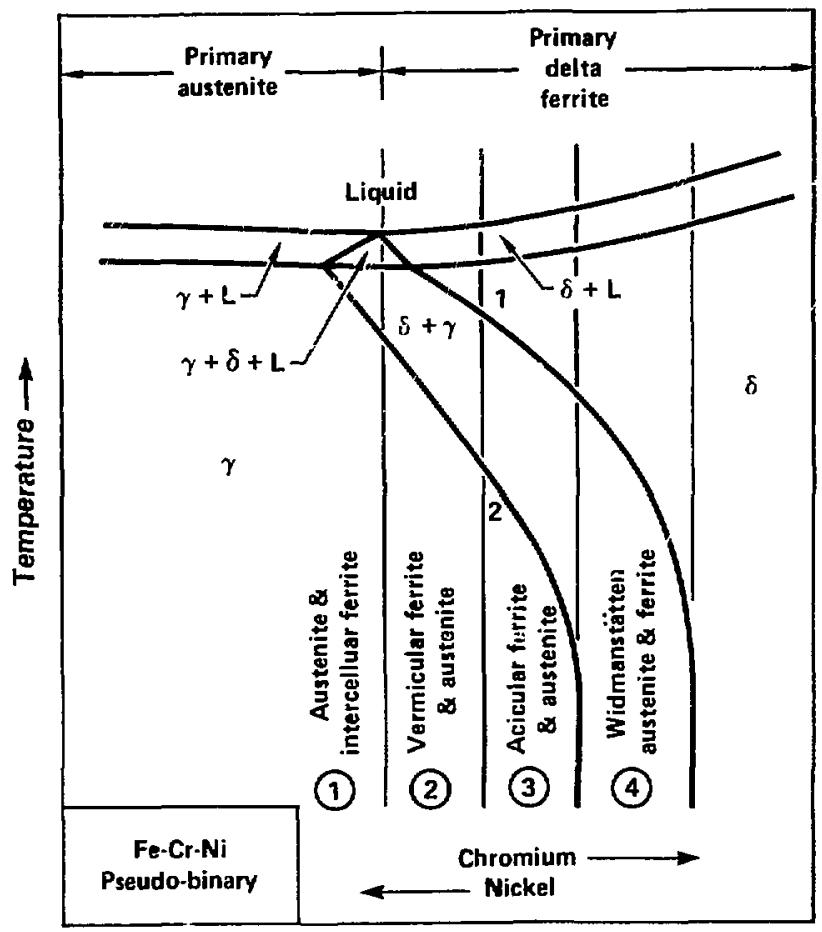


Dalder, Juhas - Figure $2 b$

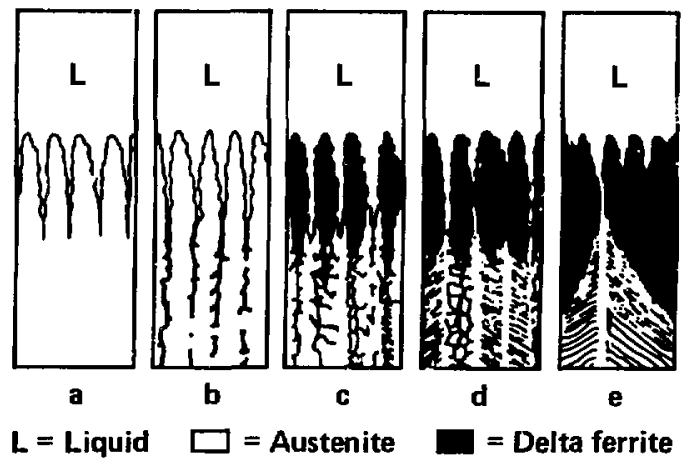


Dalder, Junas - Figure 26

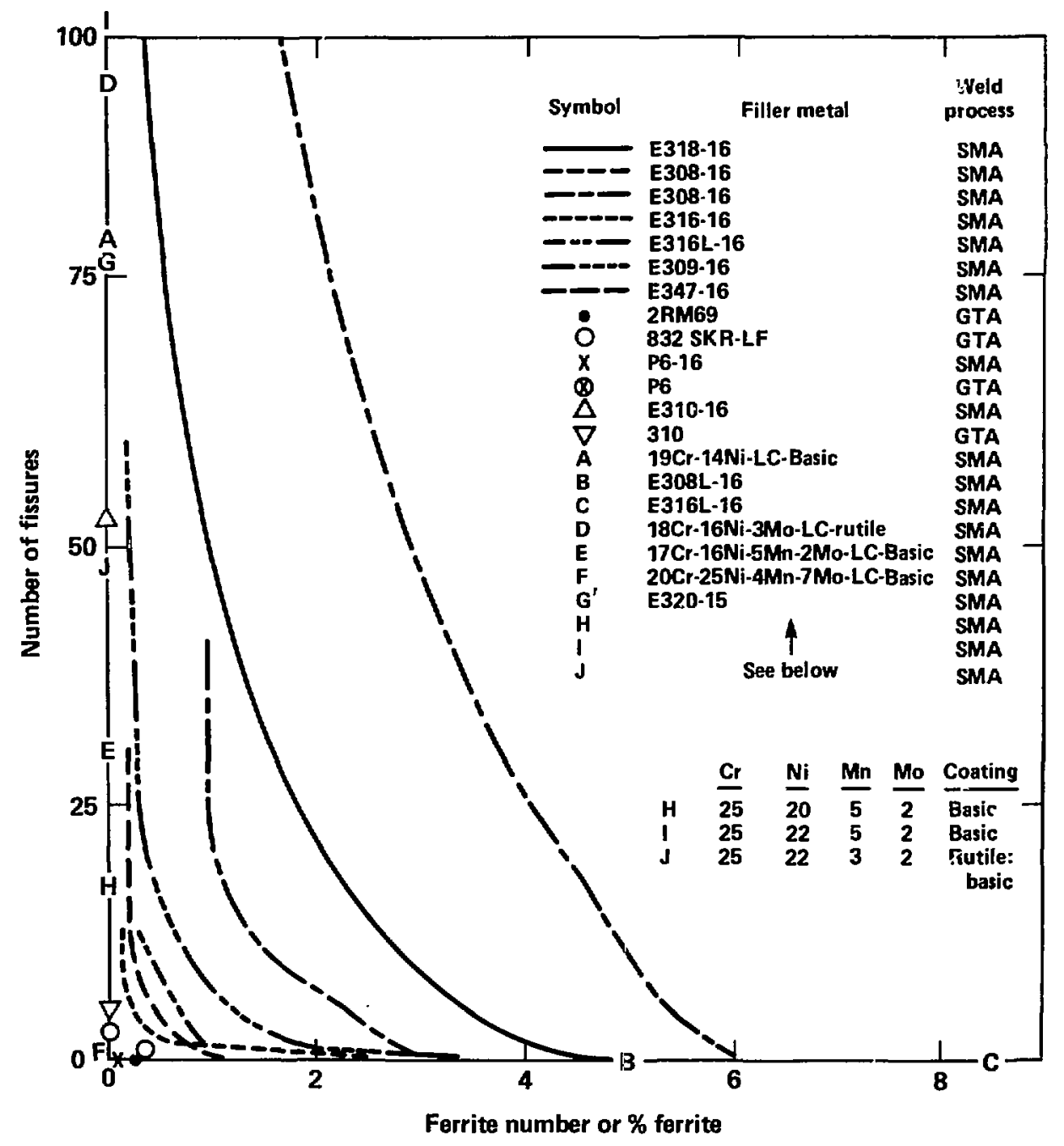


Dalder, Juhas - Figure 27

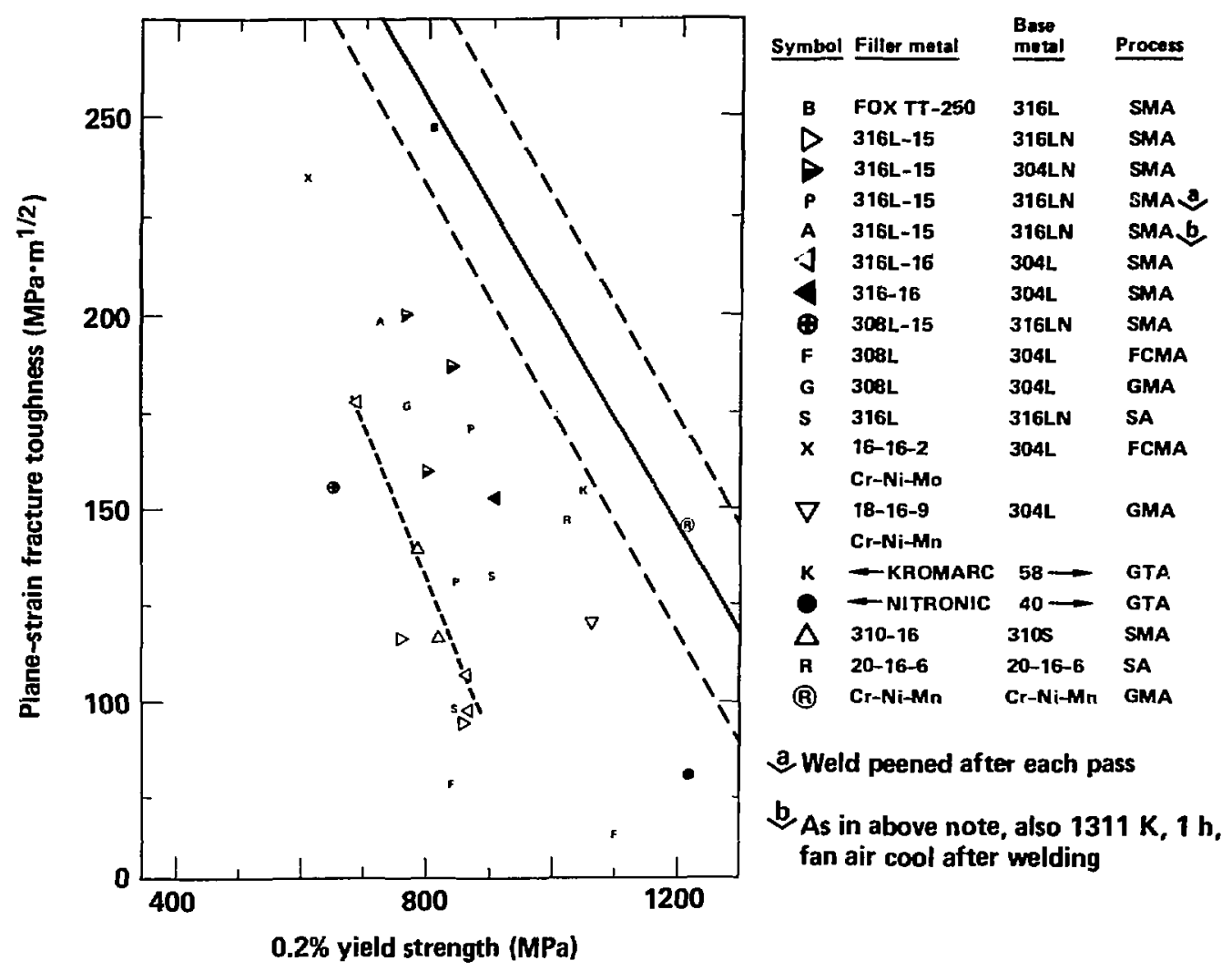


Dalder, Juhas - Figure 28

\begin{tabular}{|c|c|c|c|c|c|}
\hline \multicolumn{6}{|c|}{ Major elements (\%) } \\
\hline Symbol & $\mathrm{Cr}_{\mathbf{r}}$ & $\mathbf{N i}$ & Mn & Mo & $\begin{array}{l}\text { Weld } \\
\text { process }\end{array}$ \\
\hline B & 17 & 16 & 4 & 2.2 & SMA \\
\hline$D$ & 20 & 16 & 7 & 2.8 & SA \\
\hline 4 & 18 & 20 & 6 & $\ldots$ & GMA \\
\hline 4 & 18 & 20 & 6 & $\ldots$ & GMA \\
\hline$\nabla$ & 18 & 16 & 9 & $\ldots$ & GMA \\
\hline 0 & 16 & 16 & 4 & 1.5 & FCMA \\
\hline$\sqrt{2}$ & 16 & 15 & 4 & 1.8 & SMA \\
\hline+ & 20 & 10 & 2 & $\ldots$ & SMA \\
\hline $\boldsymbol{\theta}$ & 20 & 10 & 2 & $\ldots$ & FCMA \\
\hline 6 & 20 & 10 & 2 & $\ldots$ & GMA \\
\hline$x$ & 16 & 16 & 2 & 2 & FCMA \\
\hline$\kappa$ & 16 & 20 & 10 & 2 & GMA \\
\hline 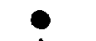 & 20 & 7 & 9 & $\ldots$ & GMA \\
\hline$\triangle$ & 27 & 21 & 2 & $\ldots$ & SMA \\
\hline$\vec{R}$ & 20 & 16 & 6 & $\ldots$ & SA \\
\hline (B) & 20 & 16 & 6 & $\ldots$ & GMA \\
\hline
\end{tabular}

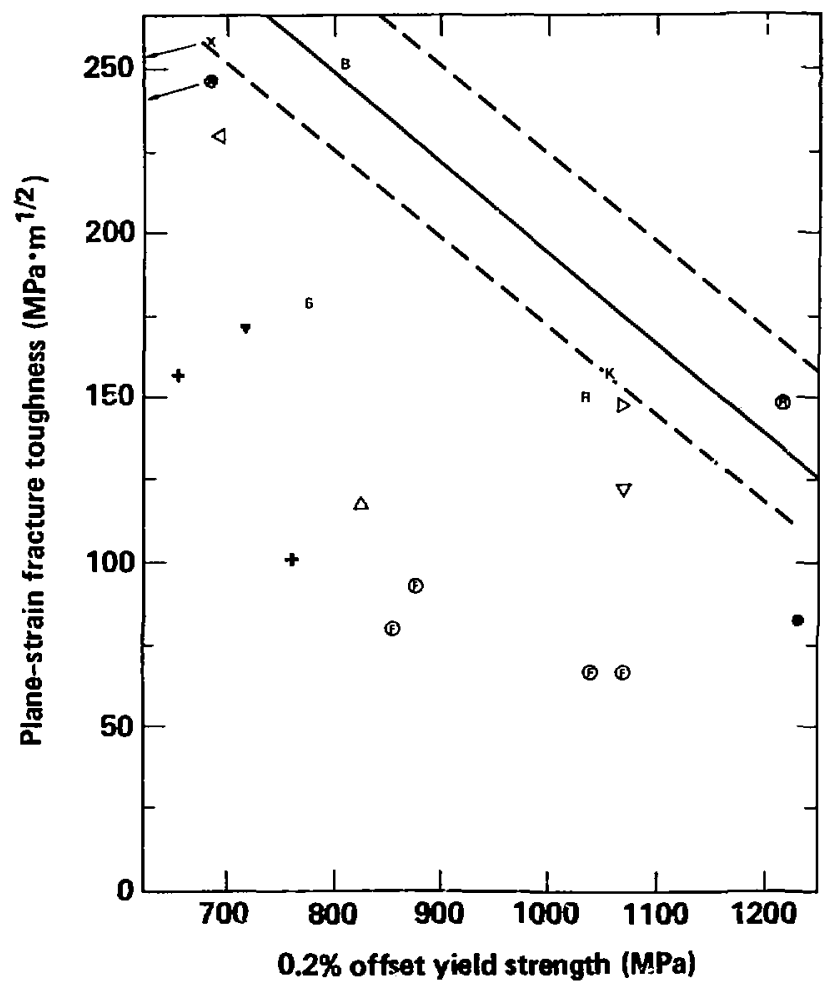




\begin{tabular}{|c|c|c|c|c|c|}
\hline Symbol & $\begin{array}{l}\text { Diam. } \\
\text { (mm) }\end{array}$ & $\begin{array}{c}\text { Weld } \\
\text { position }\end{array}$ & Symbol & $\begin{array}{l}\text { Diam. } \\
(\mathrm{mm})\end{array}$ & $\begin{array}{c}\text { Weld } \\
\text { position }\end{array}$ \\
\hline $\begin{array}{l}\theta \\
0 \\
0 \\
\theta \\
0 \\
0 \\
\theta \\
0 \\
0 \\
0 \\
0\end{array}$ & $\begin{array}{l}3.2 \\
3.2 \\
4.0 \\
4.0 \\
4.8 \\
4.8 \\
6.4 \\
6.4 \\
6.4 \\
6.4 \\
3.2 \\
4.0\end{array}$ & $\begin{array}{l}\mathbf{F} \\
\mathbf{F} \\
\mathbf{F} \\
\mathbf{F} \\
\mathbf{F} \\
\mathbf{F} \\
\mathbf{F} \\
\mathbf{F} \\
\mathbf{F} \\
\mathbf{F} \\
\mathbf{V} \\
\mathbf{V}\end{array}$ & $\begin{array}{c}0 \\
\checkmark \\
\nabla \\
\Delta \\
\nabla \\
\square \\
F=\text { flat } \\
\text { V = vertic } \\
\text { * } 16 \text { coati } \\
\text { coating }\end{array}$ & $\begin{array}{l}3.2+4.0 \\
3.2 \\
4.0 \\
3.2 \\
4.0 \\
3.2 \\
3.2\end{array}$ & $\begin{array}{c}V \\
V \\
V \\
F \\
F \\
F^{*} \\
V\end{array}$ \\
\hline
\end{tabular}

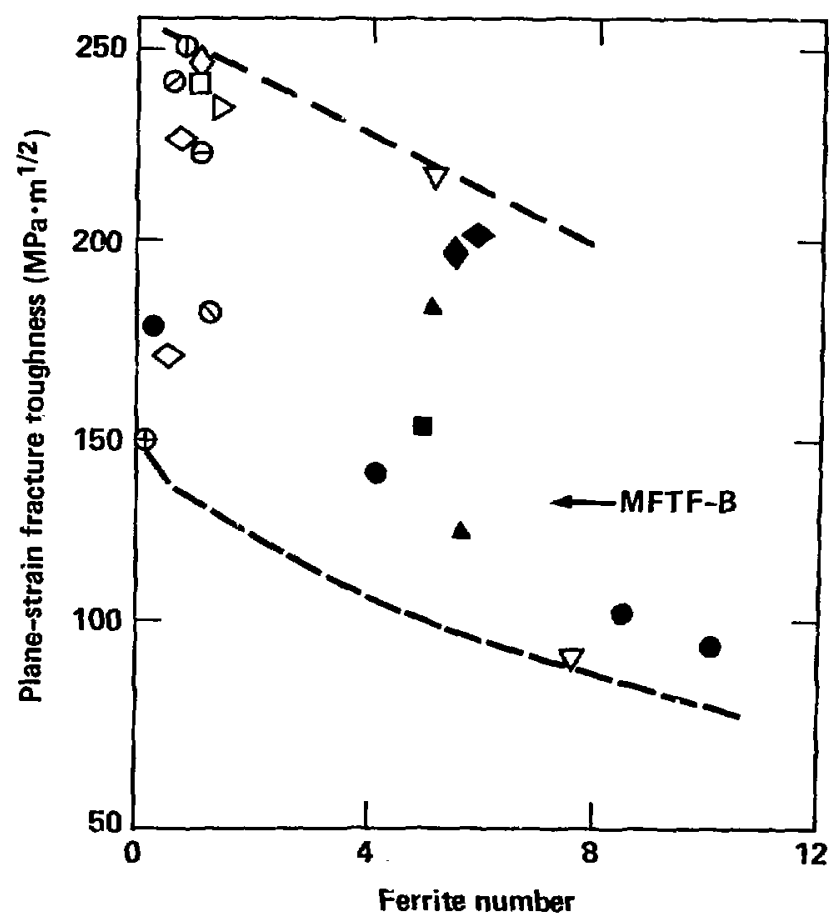


Diilder, Juhas - Figure 30

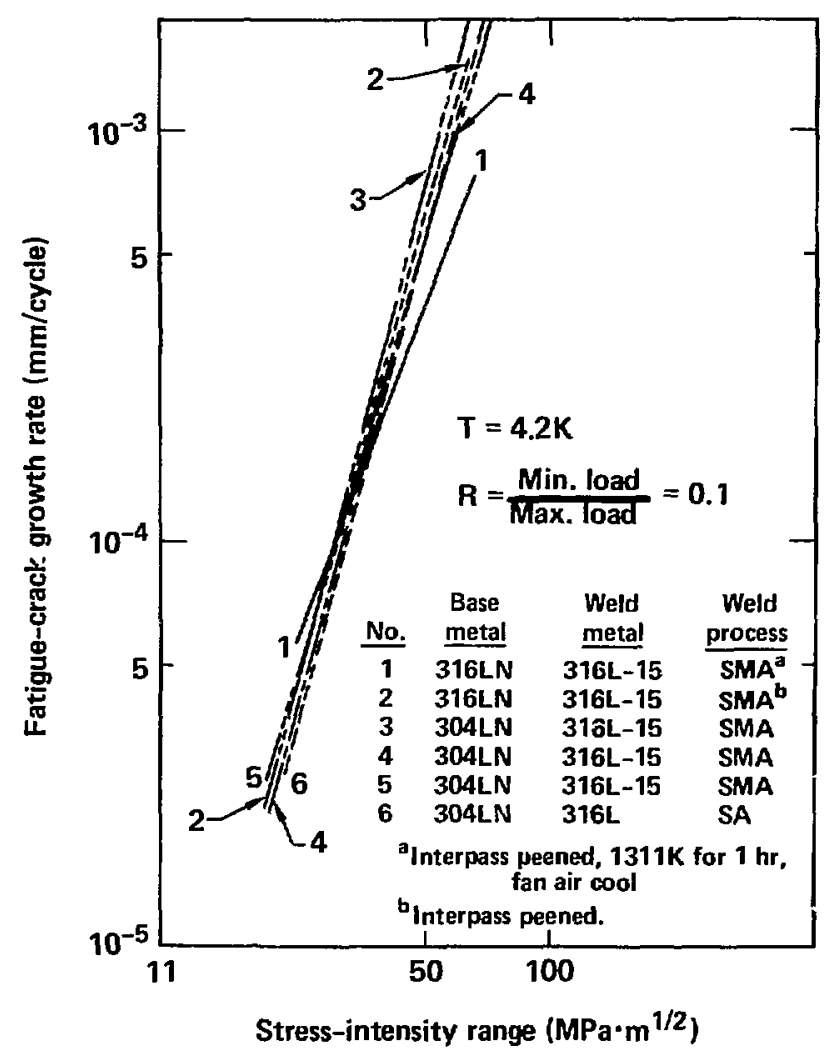


Dalder, Juhas - Figure 3 ?

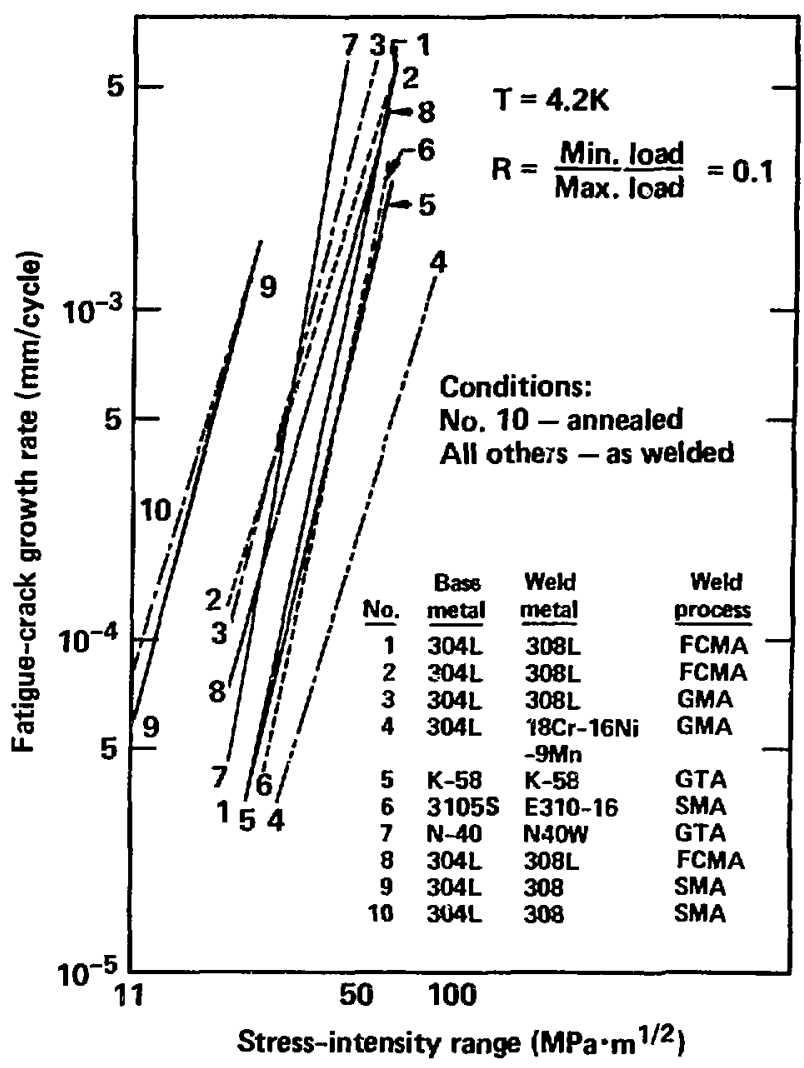


Dalder, Juhas - Figure 32

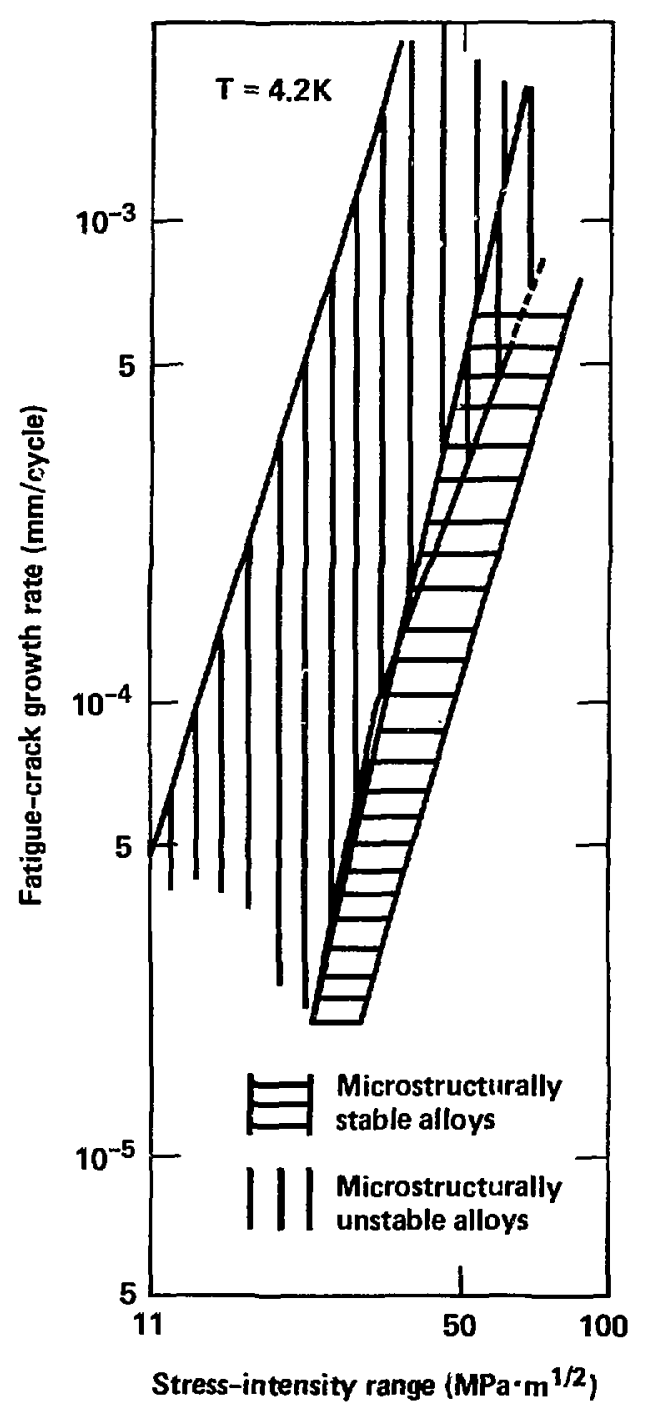

